University of Louisville

ThinkIR: The University of Louisville's Institutional Repository

Electronic Theses and Dissertations

8-2005

\title{
High tech spatial concentration human capital, agglomeration economies, location theories and creative cities.
}

Songmei Li 1970-

University of Louisville

Follow this and additional works at: https://ir.library.louisville.edu/etd

\section{Recommended Citation}

$\mathrm{Li}$, Songmei 1970-, "High tech spatial concentration human capital, agglomeration economies, location theories and creative cities." (2005). Electronic Theses and Dissertations. Paper 824.

https://doi.org/10.18297/etd/824

This Doctoral Dissertation is brought to you for free and open access by ThinkIR: The University of Louisville's Institutional Repository. It has been accepted for inclusion in Electronic Theses and Dissertations by an authorized administrator of ThinkIR: The University of Louisville's Institutional Repository. This title appears here courtesy of the author, who has retained all other copyrights. For more information, please contact thinkir@louisville.edu. 


\title{
HIGH TECH SPATIAL CONCENTRATION \\ HUMAN CAPITAL, AGGLOMERATION ECONOMIES, LOCATION THEORIES AND CREATIVE CITIES
}

\author{
By \\ Songmei Li \\ M.S., East China Normal University, 1995 \\ B.S., Northeast Normal University, 1992
}

\begin{abstract}
A Dissertation
Submitted to the Faculty of the

Graduate School of the University of Louisville

In Partial Fulfillment of the Requirements

For the Degree of

Doctor of Philosophy

Department of Urban and Public Affairs

College of Business and Public Administration

University of Louisville

Louisville, Kentucky
\end{abstract}

August 2005 
Copyright 2005 by Songmei Li

All rights reserved 


\title{
HIGH TECH SPATIAL CONCENTRATION HUMAN CAPITAL, AGGLOMERATION ECONOMIES, LOCATION THEORIES AND CREATIVE CITIES
}

\author{
By \\ Songmei Li \\ M.S., East China Normal University, 1995 \\ B.S., Northeast Normal University, 1992 \\ A Dissertation Approved on \\ May 17, 2005 \\ By the following Dissertation Committee:
}

Dissertation Director 


\title{
DEDICATION
}

This dissertation is dedicated to my parents

\author{
Mr. Jingxiang Li \\ and
}

Mrs. Feng Shi

who have given me generous support and invaluable educational opportunities. 


\section{ACKNOWLEDGEMENTS}

It is very hard to express in words my appreciation for the help, advice and encouragement I received over these years. First, I would like to thank my dissertation advisor, Dr. Thomas Lyons, for his continuous guidance, patience, and support throughout my Ph.D. studies. I also appreciate the guidance and contribution of my other committee members and professors, Dr. Wayne Usui, Dr. Ronald Vogel, Dr. David Simpson, and Dr. Allen Furr for their valuable comments and assistance. This work was not done without their help. I would also like to express my thanks to other colleagues in the school, my classmates Takatsu Tsukamoto, Ming Yin, Jian Sun, Lin Ye, and many other people who offered me valuable help in this study. I also would like to express my thanks to my parents, Jingxiang Li and Feng Shi, for their generous support, assistance, and encouragement for my studies abroad. 


\begin{abstract}
HIGH TECH SPATIAL CONCENTRATION

HUMAN CAPITAL, AGGLOMERATION ECONOMIES, LOCATION THEORIES

AND CREATIVE CITIES
\end{abstract}

Songmei Li

April 1, 2005

This study explores four economic development theories - classical location theory, human capital theory, agglomeration economies theory and creative cities theory, and their effectiveness in explaining the spatial distribution of high tech industries across metropolitan areas. This study identifies a strong and positive role for education and topranked research universities on high-tech employment concentrations, thus supporting the human capital approach that promotes investment in education and academic R\&D to stimulate regional high technology economic development. This study also suggests that successful high technology regions are the regions with the presence of multi-regional and multinational corporate headquarters and accessibility to an international airport. In addition, the findings from the regression analyses could not provide strong support for localization economies and creative cities theories. 
TABLE OF CONTENTS

PAGE

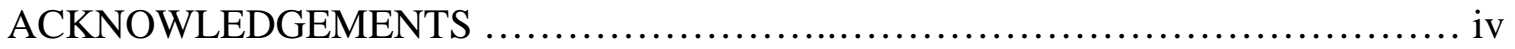

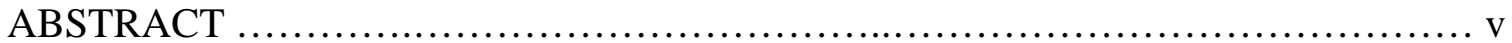

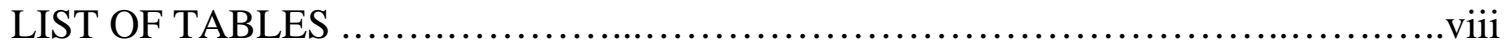

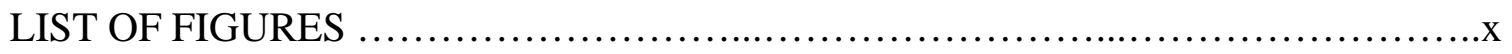

\section{CHAPTER}

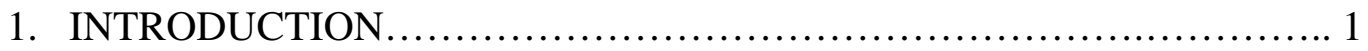

2. THEORIES ON HIGH TECH ECONOMIC DEVELOPMENT............... 6

CLASSICAL LOCATION THEORY .................................. 6

HUMAN CAPITAL THEORY ....................................... 9

AGGLOMERATION ECONOMIES THEORY........................13

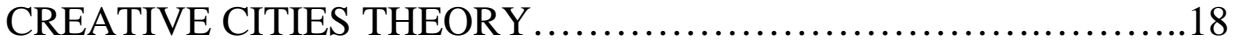

3. LITERATURE REVIEW ON THE LOCATION OF HIGH TECH

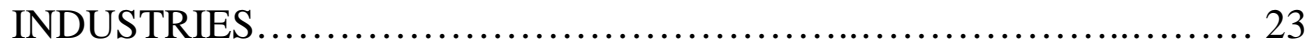

A young, well-educated labor force................................. 24

Proximity to top-ranked research universities........................ 26

Regional amenities and an attractive quality of life factors............. 29

Agglomeration economies......................................... 32

Reasonable production cost.......................................... 33

Diversity and creative social environment ........................... 34 


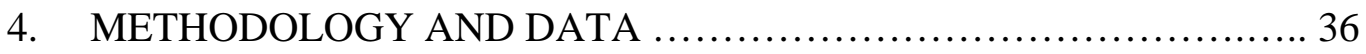

5. WHERE ARE HIGH-TECH INDUSTRIES LOCATED? ................... 51

High-Tech Industries: Definition ................................. 51

Inter-Metropolitan Distribution of High-Tech Industries............... 55

Spatial Allocation of High Tech Industries by Industrial Sectors....... 60

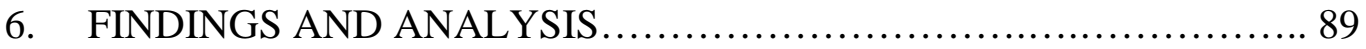

Human capital factors on high tech employment .................... 93

Quality of life factors on high tech employment ................... 95

Agglomeration economies factors on high tech employment ......... 99

Classical location theory factors on high tech employment ...........103

Creative cities factors on high tech employment .................... 107

7. CONCLUSIONS AND RECOMMENDATIONS......................113

Summary and public policy implication ............................113

Limitation and recommendations for future research ............... 117

REFERENCES......................................................... 122

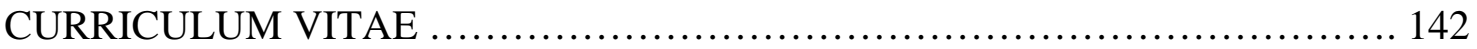




\section{LIST OF TABLES}

$\begin{array}{ll}\text { TABLE } & \text { PAGE }\end{array}$

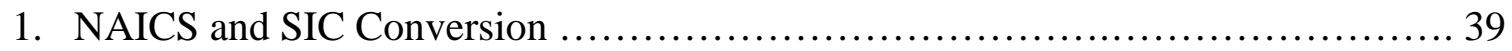

2. R Squares of Multiple Regressions for Each Theory $\ldots \ldots \ldots \ldots \ldots \ldots \ldots \ldots \ldots \ldots \ldots .40$

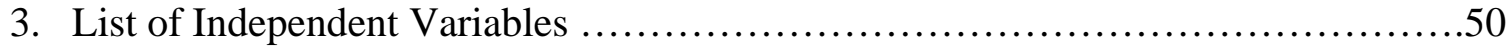

4. High-Tech Industries Definition ....................................... 52

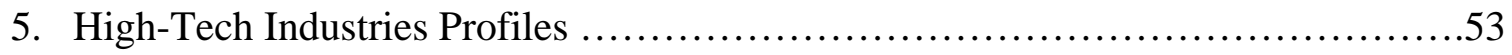

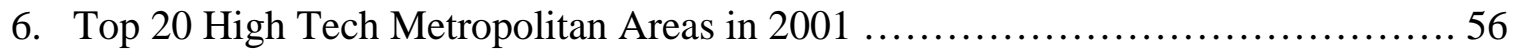

7. Top 20 High Tech Gain and Loss Metropolitan Areas ........................... 58

8. Ranks for Top High Tech Metropolitan Regions in 1998, 2001....................59

9. Top Ten Metropolitan Areas by High Tech Sectors, 2001 ........................ 61

10. Spatial Gini Coefficients for High-Tech Industries ........................... 63

11. Pharmaceutical and Medicine Manufacturing (NAICS 3254) ..................... 66

12. Computer \& Electronic Product Manufacturing (NAICS 334) ....................68

13. Aerospace Product and Parts Manufacturing (NAICS 3364) .....................71

14. Medical Equipment and Supplies Manufacturing (NAICS 3391) ................ 74

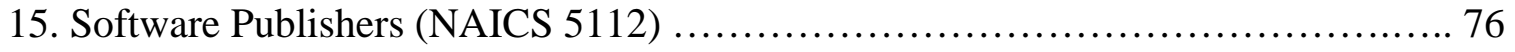

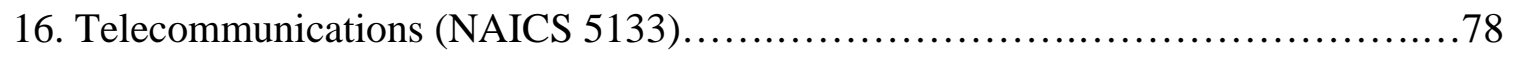

17. Information and Data Processing Services (NAICS 514) ...................... 80

18. Architectural, Engineering \& Related Services (NAICS 5413) .................. 82

19. Computer System Design \& Related Services (NAICS 5415) .................. 84 


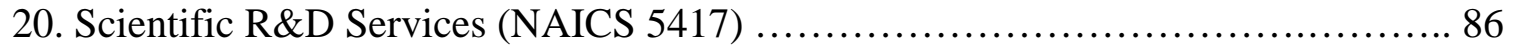

21. Summary of Climate and Crime Rate estimating high tech employment ............. 91

22. Summary of Human Capital Variables estimating high tech employment........... 93

23. Summary of Quality of Life factors estimating high tech employment .............. 97

24. Summary of Agglomeration Economies variables estimating high tech employment..

25. Summary of Classical Location Theory variables estimating high tech employment ... .104

26. Summary of Creative Cities Theory variables estimating high tech employment....108

27. Summary of Regression Coefficients estimating high tech employment 


\section{LIST OF FIGURES}

$\begin{array}{ll}\text { FIGURE } & \text { PAGE }\end{array}$

1. Spatial Distribution of High Tech Employment 2001.............................55

2. High Tech Employment Change 1998-2001................................ 57

3. Spatial Allocations of Pharmaceutical and Medicine Manufacturing, 2001 ........ 65

4. Spatial Allocations of Computer and Electronic Product Manufacturing in 2001... 67

5. Spatial Allocations of Aerospace Product and Parts Manufacturing in 2001 ........ 70

6. Spatial Allocations of Medical Equipment and Supplies Manufacturing in 2001 ....73

7. Spatial Allocations of Software Publishers in 2001 .......................... 75

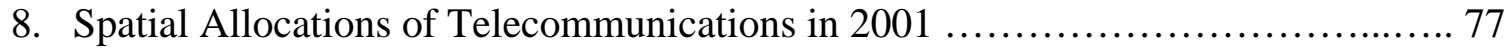

9. Spatial Allocations of Information and Data Processing Services in 2001 ......... 79

10. Spatial Allocations of Architectural, Engineering \& Related Services in 2001 ......81

11. Spatial Allocations of Computer System Design \& Related Services in 2001 ...... 83

12. Spatial Allocations of Scientific R\&D Services in 2001 ....................... 85 


\section{CHAPTER 1}

\section{INTRODUCTION}

In the 1990s, advances in information technology, such as computer and telecommunication technology and the Internet, were propelling the growth of America's economy. The Economic Report of the President (No. 104) estimated that the computer and telecommunication industries contributed between 21 and 31 percent of the U.S. GDP growth in each of the years from 1995 to 1998. In research on America's high technology economic development, the Milken Institute claims that two-thirds of national economic growth can be attributed to high technology industries in the 1990s (DeVol 1999). High technology industries, especially in software, computers and the Internet, were creating many new high paying and challenging jobs. Their spillover impacts also benefit traditional industries in terms of productivity gains, business expansion, and creation of high wage jobs (Hecker 1999). In response to information revolution and economic restructuring, cities or regions around the nation have worked hard to generate and attract high technology businesses into their jurisdictions. For instance, Silicon Valley, Route 128, Austin, Phoenix, Salt Lake City, and North Carolina's Research 
Triangle are successful metropolitan areas in applying high tech development strategies to foster economic growth (Castells 1989, Castells and Hall 1994, Saxenian 1994, Kaderlan and Ronstadt 1998, Lee, Miller, Hancock, and Rowen 2000, Cortright and Mayer 2001, Lincoln Institute of Land Policy 2001).

In the last two decades, many scholars have been seeking to explain the location of high tech industries and the primary factors that influence the high technology growth in a region. These studies used different indicators and addressed the same economic phenomenon from different paradigms. Markusen, Hall and Glasmeier suggest that four serious of key factors have great impacts on the regional high technology distribution: quality of life factors such as pleasant climate, access to transportation networks such as airport and freeway, agglomeration economies like the presence of corporate headquarters, and socio-political factors such as federal defense spending (Markusen, Hall and Glasmeier 1986). In America's High Tech Economy: Growth, Development, and Risks for Metropolitan Areas, the Milken Institute identifies a range of factors that affect high tech growth in the metropolitan areas, which include an educated workforce, proximity of a top ranked research institution, presence of suppliers and business networks, production costs, existence of venture capital, tax incentives, commercialization of ideas, climate, housing and other quality of life factors (DeVol 1999). Economic growth theorists have also focused their attentions on the role of research universities in regional high tech growth. For instance, case studies in high 
technology development in San Jose, California (Castells and Hall 1994), Boston (Castells and Hall 1994), and Austin, Texas (Kaderlan and Ronstadt 1998) have documented the crucial roles of Stanford University, Massachusetts Institute of Technology, and University of Texas in the growth of these regions. Howells (1984) and Malecki (1980) argue that a qualified human capital, research universities and firms' headquarters, and the existence of a dense network of interactions drive the spatial concentrations of innovations. Simmie, Sennett, Wood, and Hart claim that interregional and international business linkages promote local high technology growth (Simmie, Sennett, Wood, and Hart 1992). Saxenian states that cultural diversity and openness to immigrants is a crucial factor in the Silicon Valley's high technology success in the 1990s (Saxenian 1994).

\section{Research Questions and Research Objective:}

What are the location preferences for high tech businesses? In other words, what primary factors contribute to high technology economic development in a region? This question has intrigued a range of studies in the economic development field. Various theories are being developed seeking to explain spatial allocation and growth of high tech economic activities. In this dissertation, I explore four theories on high tech economic development: classical location theory, human capital theory, agglomeration economies and creative cities theory. The objective of this study is to test the effectiveness of these theories in explaining spatial allocation of high technology industries among regions. 
This study is particularly important in three respects. First, it will enhance our knowledge and understanding of location behaviors of high tech industries, and enrich or extend existing theories on high tech economic development. Second, there are many empirical studies on the location of high tech industries and the impact of location factors on high tech spatial concentration. However, there is limited research that combines economic development theories with location factors mentioned in the empirical studies. This study fills the gap by bridging the theoretical and empirical literatures. Third, the results of this study will provide recommendation and suggestion for future economic development research and regional technology development policy. State and local government can adopt appropriate high tech development strategies that specially target important regional characteristics for promoting high tech regional economic growth. For instance, if research institutions play a crucial role for high technology economic development, state and local governments should give priority to enhance the research capabilities of local universities by strengthening their science and technology programs. This research will provide helpful information for the metropolitan regions to adopt appropriate high tech economic development strategies to stimulate economic growth.

What are high-tech industries? How do we define high tech? From the literature, researchers define high tech mainly from two perspectives. One definition is high-tech industrial employment. County business patterns have listed mid-March employment data 
based on North American Industry Classification System (NAICS) code since 1998. Another popular definition is high tech occupations. Bureau of Economic Analysis has employment data classified by occupation, including computer occupation, engineering and scientists. It has more accurate data on high tech professionals, but it does not classify them by industrial sectors. Because this study is not only interested in total high tech profile, but also interested in individual high tech sectors, industrial employment data are more appropriate for the present research.

This study is organized into seven chapters. Following this introduction, there is a brief review of four theories and the explanations offered by them as to why high tech industries grow in some regions and decline in others. The third chapter conducts a literature review on the theoretical and empirical analysis of location factors on high tech spatial distribution and further links these factors with the four theories to explain the spatial pattern of high tech industries. The fourth chapter discusses methodologies and data sources of this study, and the fifth chapter explores the spatial patterns of high tech industries among the metropolitan regions. The sixth chapter outlines the findings on the importance of location factors on high tech industrial concentration, and further refers to theories on their effectiveness in explaining the location of high tech industries. Finally, the last chapter proposes recommendations and suggestions for further research on high tech economic development. 


\section{CHAPTER 2}

\section{THEORIES ON HIGH TECH ECONOMIC DEVELOPMENT}

In recent years, a growing number of scholars have shown great interest in the spatial allocation of high tech economic development. A wide range of theories was developed seeking to uncover the reasons that high tech industries cluster in some geographic regions rather than others. However, there is no dominating theory, or consensus, today as to theoretical perspectives on the determinant forces driving high tech economic growth. Different theories address this issue from their own specific perspectives. In the following section, I will review four relevant theories that attempt to explain directly or indirectly the reasons for high tech industrial development in regions. This will give a sound theoretical background to the empirical studies on the location of high tech industries in the next chapter.

\section{Classical Location Theory}

Classical location theory was originated from Alfred Weber's book, Theory of the Location of Industries, published in 1909 in German and translated into English by Carl Friedrich twenty years later. Weber attempted to construct a theoretical methodology to 
determine the optimum location for a firm. The principle is the minimum transportation cost model (Weber 1929).

Weber believes firms choose an optimum location with minimum total transportation costs between the sources of inputs (raw materials) and the output (market products). In other words, businesses were located near railroads or waterways, and close to natural resources, such as coal, to minimize the transportation cost. Weber developed a location triangle, called the Weberian Triangle by later researchers, to calculate the optimal location for a firm. He also suggests that labor costs and agglomerative forces can shift a firm's location from the previously calculated optimum site. In other words, the interaction of three factors - transportation costs, labor costs and agglomeration costs explain the location of firms (Weber 1929).

Weber's Classical location theory has established the foundations of modern location theories. It explains well the location of heavy industries, particularly from the nineteenth and early twentieth century, which were very much dependent on transportation costs. In Weber's model, transportation is the most important element. The other two factors are considered to have an adjustment effect. Weber assumes that transportation cost is a function of weight and distance. He does not consider the cost of intermediate shipping and handling at intermediate locations, which becomes very common in the modern world. In addition, technological development has dramatically decreased transportation 
costs. For most modern industries, transportation costs constitute for only a small portion of total production and transaction costs (Premus 1982, Button 1988). With increasing competition from technological revolution and economic globalization, transit time becomes more crucial than transportation cost for high tech businesses. In other words, transportation does not mean the costs of moving materials to the firm and products to market; transportation means moving managerial and technical professionals through high level, rapid transportation facilities such as air travel. Weber's assumption may not be valid in the modern industrial environment. Moreover, classical location theory analyzes space or industrial locations as a geometric concept. However, in most modern cluster-based theories, space is also viewed as a social and cultural phenomenon. Social and economic factors such as a knowledge-based labor force, a diverse and creative social environment, technological capabilities, and quality of life factors have been increasingly introduced in modern location theories (Atkinson and Gottlieb 2001; Blakely 2001; Cohen 2000; Cortright 2001a, 2001b, 2002; DeVol 1999; Florida 2000, 2001, 2002; Glaeser and Shapiro 2001, Romer 1986, Lucas 1988).

Classical location theory is one of the most important branches of urban and regional economics. It has been a dominant theory for explaining business locations for a century. However, it does not foresee the impact of the information revolution and ignores the critical contributions of knowledge as the driving forces for economic growth. The Classical location theory needs to be revised or extended to better address location 
behaviors for modern high tech enterprises.

\section{Human Capital Theory}

Developed by the University of Chicago economist Robert E. Lucas, human capital theory states that human capital is the determinant for high tech economic development. In human capital theory, technological progress is contributed by rational investments in research and education. The investments in human capital have increasing returns to the productivity of both physical capital and the general labor force (Lucas 1988). Following Lucas, Black and Henderson suggest that human capital stimulates endogenous high tech economic growth. The concentration of educated people produces external effects by sharing knowledge and skills through formal and informal interaction. High tech economic growth depends on the ability to absorb existing knowledge and to create new knowledge, both of which are dependent on the existing stock of human capital (Black and Henderson 1999). In addition, the movement of labor among firms creates a learning system that promotes innovative activities such as in Silicon Valley (Saxenian 1994). The accumulation of human capital improves productivity and drives high tech economic growth in a region.

Human capital theory is supported by a wide range of theoretical and empirical studies, which document the close association between human capital and regional 
economic growth (Lucas 1988, Romer 1986, 1990, Krugman 1991a, b, Grossman and Helpman 1991, Rauch 1993, Glaeser, Scheinkman, and Shleifer 1995, Glaeser 1998, 1999a, 1999b, 2000, Simon 1997, Davenport 1999, Black and Henderson 1999, Malecki 1997, 1999). Some scholars find a positive relationship between human capital and employment growth (Simon and Nardinelli 1992, 1996, Glaeser, Scheinkman, and Shleifer 1995). Simon states that the average level of human capital is strongly positively associated with employment growth across U.S. MSAs between 1940 and 1986 (Simon 1997). Malecki suggests that the success of high tech growth in a region depends on whether the region could incorporate knowledge and learning into the local innovation system (Malecki 1999). Armington argues that an educated, technically skilled labor force and urban amenities are very important for high tech firms' location decisions (Armington 1986). Feser documents the strategic role of educational attainment and university research on high technology measuring and controlling devices industry (Feser 2002). Simmie, Sennett, Wood, and Hart list a professional and skilled labor force and the learning systems as the most important considerations for high tech firms to choose a location (Simmie, Sennett, Wood, and Hart 2002). Rauch, in his wage and rent model, demonstrates that each additional year of SMSA average education can be expected to raise total productivity by 2.8 percent. His model explains how accumulation of human capital increases productivity (Rauch 1993). Carton argues that a large technical labor force significantly increases the births of new high tech firms in an MSA (Carton 1997). Castells documents the important roles of top research universities on high tech cluster 
development in Boston and San Jose metropolitan areas (Castells 1989). Glaeser states that the levels of human capital are strongly associated with economic growth rates across countries. Human capital is the engine for growth (Glaeser 1994). Mathur suggests that the accumulation and promotion of human capital promotes long-term regional economic growth, especially for technology-complicated industries (Mathur 1999). In his New Growth Theory, Romer advocates that generation of new knowledge, which is determined by the existing stock of human capital, is the key to economic progress (Romer 1986). Following Romer, Barro examines a sample of countries over the past 30 years and finds that human capital variables such as education are particularly important for driving growth (Barro 1992).

Extended from human capital theory, many researchers also suggest the importance of quality of life factors by stating that regional amenities and environmental quality attract knowledgeable workers, and these skilled workers further attract more high tech firms into the region. Since the most important input for high technology industries is knowledge workers, quality of life factors are considered very crucial in attracting and retaining a high-quality work force, and are highly ranked by high technology businesses (Blair and Premus 1987, Schmenner 1982, Haug 1991, Gottlieb 1995, Granger and Blomquist 1999, Florida 2000, Salvesen and Renski 2002). 
Human capital theory explains spatial concentrations of high tech industries by differences in regional investments in research and education among regions. However, some researchers point out that there is little relationship between academic research and innovative activities or high tech growth in a region (Howells 1984, Markusen et al. 1986, Glasmeier 1991, Florax and Folmer 1992, Beeson and Montgomery 1993). Malecki and Feldman argue that the presence of a top research university does not necessarily lead to the development of a high tech center as in the case in Johns Hopkins University in Baltimore (Malecki 1997, Feldman 1994b). Gray, Golob and Markusen find that the University of Washington does not significantly influence the evolution of the aerospace and software industry in the Seattle metropolitan regions (Gray, Golob and Markusen 1996). Mayer states that high tech clusters could be developed without the presence of a top ranked research university, as in the Silicon Forest in Portland (Mayer 2003). Some scholars also argue that investment in education may not produce a direct impact on the local economy. Research findings from scientific laboratories in local universities may be applied and commercialized in other regions thousand of miles away (Fogarty and Sinha 1999). Science and engineering students may move out of regions after they graduate. In this way, local universities play a role in providing high tech professionals and innovations for other regions rather than satisfying the local high tech development needs. 


\section{Agglomeration Economies}

Agglomeration was introduced by Weber $(1909,1929)$ in his classical location theory and by Marshall (1920). Weber listed agglomeration as one of three determinant factors on industrial location. Marshall ([1890], 1920, chapter X) states that agglomerations generate a lock-in effect through mass production, local specialized input services, a highly skilled labor force and shared infrastructure.

Agglomeration economies theory was originated from the observance of spatial clusters of related industries within a geographic area. The principle of agglomeration theory is that spatial concentration of production facilities produces cost saving effects by locating close to each other. There are two types of agglomeration economies. One relates to firms engaged in similar or inter-linked activities, leading to spatial clusters of relevant firms in a region. It has been called Marshall-Arrow-Romer (MAR) externalities or Localization Economies. Many researchers argue that firms belonging to the same sector benefit from a higher productivity and innovation when they locate together (Sveikauskas 1975, Moomaw 1981, Nakamura 1985, Henderson 1986, Henderson, Kuncoro, and Turner 1995, Ciccone and Hall 1996, Henderson 1997, Black and Henderson 1999, Beardsell and Henderson 1999, Belleflamme, Picard, and Thisse 2000). Henderson argues that initial concentration of own industry activities will affect employment levels for five or six years after (Henderson, Kuncoro, and Turner 1995, Henderson 1997). 
Porter $(1990,2000)$ believes that "industry clusters", geographic concentrations of interconnected companies, produce competitive advantage. Another type of agglomeration economies is called Urbanization Economies, which are the general economies arising from the overall level of activities that apply to all firms and industries in a single location (Goldstein and Gronberg 1984, Helsley and Strange 1990, Haug 1991, Glaeser, Kallal, Scheinkman, and Shleifer 1992, Henderson, Kuncoro and Turner 1995, Henderson 1997, Feldman and Audretsch 1999, van Soest, Gerking, and van Oort 2002). Quigley suggests that cities with increased size and diversity are strongly associated with productivity, innovation and growth, showing the increasing returns from urbanization economies (Quigley 1998).

In both cases, firms benefit through lower cost of production by sharing the localized labor pool and infrastructure (Hoover 1948, Lloyd and Dicken 1977, Helsley and Strange 1990, Dumais, Ellison, Glaeser 1997, Malecki 1999, Rosenthal and Strange 2001, Feser 2002), enhanced links between local suppliers and customers (Hoover 1948, Lloyd and Dicken 1977, Goldstein and Gronberg 1984, Scott 1986, Goe 1991), reduced production costs by locating production facilities near large markets (Krugman 1991a, b, c), and local knowledge spillover (Jaffe and Trajtenberg 1993, Acs, Audretsch and Feldman 1994, Malmberg, Solvell, and Zander 1996, Alemeida and Kogut 1997, Glaeser 1999b, Rosenthal and Strange 2001, Koo 2003). Dumais, Ellison and Glaeser argue that 
industries with similar labor forces enjoy the highest profit by locating close to each other, indicating the importance of labor market pooling (Dumais, Ellison and Glaeser 1997). Haug states that labor agglomeration factor plays a significant role on high tech industrial concentration in the Washington state (Haug 1991). Malecki claims that labor market pooling and large number of specialized producers in a region help firms to minimize transaction costs (Malecki 1999). Rodriguez-Pose suggests that social factors that promote both innovation and a greater assimilation of innovation are related to high skills and higher dynamism in the regional labor market (Rodriguez-Pose 1999). Krugman has established a theoretical model that illustrates industrial agglomeration as a product of labor market pooling behavior. In his industrial location model, firms and workers find it profitable to look for locations where each are abundant, leading them to cluster in a region that have an early lead in a particular industry. He further states that labor market pooling, intermediate inputs and technology spillovers are three major sources of agglomeration economies (Krugman 1991a). Henderson argues that industry-specific external economies increase due to the positive spillovers among businesses located nearby. This positive external impact declines with distance (Henderson 1974, 1977, and 1988). Saxenian suggests that the open managerial structure of high technology firms in Silicon Valley increases formal and informal communication among firms, thus giving the region an advantage over the relatively hierarchical managerial structure of large high tech businesses in Boston's Route 128. She therefore identifies knowledge spillover as an agglomeration force (Saxenian 1994). Wheeler, Mody and Smith and Florida argue that 
agglomeration economies are positively associated with corporate location decisions (Wheeler and Mody 1992, Smith and Florida 1994). Agglomeration economies reduce the cost of innovation by enhancing knowledge spillovers while reducing labor costs and intermediate inputs cost through labor market pooling and input sharing, thus improving the productivity and innovativeness of local firms and promoting high tech economic growth in regions (Henderson 1986, Beeson 1987, Moomaw 1988, Fogarty \& Carofalo 1988, Krugman 1991a, Feser 2001).

One pitfall for agglomeration theory is that it does not explain how agglomeration economies were originated; in other words, what forces contribute to the original clustering in a region. Some researchers state that economies of scale on the local industry level do not really create growth. In a study on 30-year employment patterns across SMSAs, Glaeser, Kallal, Scheinkman, and Shleifer (1992) found that initial employment concentration is negatively correlated with later growth. In addition, a study on the geographic distribution of U.S. manufacturing industries between 1972 and 1992 shows that new firm formation did not occur in industrial concentrated regions, but dispersed to less concentrated areas. This trend could not be explained by agglomeration economies theory (Dumais, Ellison, and Glaeser 2002). Clinitz argues that a regional cluster of production facilities with their major suppliers does not necessarily promote productivity and entrepreneurship (Clinitz 1961). Van Soest, Gerking, and van Oort claim 
that initial employment in a city-level industry does not have a determinant impact on future employment growth (van Soest, Gerking, and van Oort 2002). McCann claims that a large proportion of firms have few or no business linkages with other local firms within the same industry, even when there is a strong spatial clustering of a particular industry in a region (McCann 1995).

Some scholars also criticize the local knowledge spillover model by stating that knowledge can be transmitted between high-level nodes located on different continents. They argue that the reason that some metropolitan regions concentrate high tech industries is their capacities to search for and generate new economic knowledge to stimulate innovation rather than local knowledge spillovers (Simmie 2003). In a study on the relationship between locations of suppliers and customers and innovative activities in five European cities, Simmie and other researchers find that local suppliers and customers do not play a significant role in their regional innovative systems. Business networking, including contacts with customers, suppliers, competitors or business services, is cited as being of considerable importance to firms. However, customers and suppliers can come from other regions and countries. In Paris and London, the majority of local firms has suppliers and customers located in other regions and other countries. A similar trend is found in other European cities (Simmie, Sennett, Wood, and Hart, 2002). Simmie then argues that economic development could not be explained by local 
concentrations of economic activities. In the globalization age, Agglomeration economies may have a new meaning: it means more business linkages with other regions and countries; it means more international and interregional activities going on in the local business system.

\section{Creative Cities Theory}

Creative cities theory, advocated by Peter Hall, states that regions that generate and tolerate new ideas and continuously adopt changing economic and technological invention are a prerequisite to a sustained high tech economy. High tech industries cluster at creative cities, where creativity and new ideas come from.

Sir Peter Hall suggests that creativity comes from cultural clashes and structural instability - uncertainty about the future. In Cities in the Civilization, Peter Hall (2000) studied twenty-one creative cities in history, such as Athens in the $5^{\text {th }}$ Century BC, Florence in the $14^{\text {th }}$ Century, London in Shakespeare's time, Vienna in the late $18^{\text {th }}$ and $19^{\text {th }}$ centuries, Paris between 1870 and 1910, and Berlin in the 1920s. He argues that these creative cities are a special kind of city in "economic and social flux" with large numbers of new and young immigrants "mixing and merging into a new kind of society" (Hall, 2000, p. 648). He further describes creative cities as "societies troubled about themselves, societies that were in the course of losing the old certainties but were deeply 
concerned about what was happening to them" (Hall, 1998, p. 285). Creative people in creative cities feel themselves as outsiders, since they are young and foreign. They have their own social values and cultures that "do not belong to the established order of power and prestige" (Hall, 2000, p. 646). They experience great social and intellectual turbulence. Creative cities with mixed cultural and social backgrounds provide creative people with an arena for more interaction and informal information exchange, which lead to new ideas and creative thinking (Hall 2000).

A similar concept of creative cities can also be found in Jacobs's cities' diversity paradigm. In The Economy of Cities (1969) and Cities and the Wealth of Nations (1984), Jacobs argues that the diversity of local residents stimulates more interactions that generate new ideas. She further states that growth is a function of cities combining unrelated activities and that innovation is a result of combining seeming unrelated ideas (Jacobs 1969, 1984).

Creative cities theory is supported by a wide range of studies (Andersson 1985, Cortright 2001a, Malmberg and Zander 1996, Florida 2000, Hall 2000). Andersson argues that structural instability facilitates a synergetic environment and promotes innovation and creativity (Andersson 1985). Saxenian (1994) and Micklethwait (1997) claim that culture diversity and openness to immigrants is a crucial factor in the Silicon 
Valley's success in the 1990s (Saxenian 1994, Micklethwait 1997). Seeking other means to explain high tech concentration, Richard Florida identifies a special group of people, Creative Class, and states that creative class is the engine that drives high technology economic growth. Florida develops a Bohemian index, which accounts for the number of artists, writers and performers in a city. He further adds a Creative Class index to measure a city's concentration of knowledge workers such as scientists, engineers, and other think-tank employees. Florida argues that creative class prefers places where newcomers are accepted quickly into societies. In other words, creative places have low entry barriers for creative people. Florida proclaims that, in addition to a favorable business environment, an effective people climate that emphasizes openness to diversity and tolerance is essential to lower entry barriers for creative people and to promote high tech growth. Creative places are places that are tolerant, diverse and open to creativity. Cities and regions with great diversity and high levels of regional amenities attract a more talented creative class, who promote innovation and high tech growth in a region (Florida 2000).

Creative cities theory suggests a correlation between cultural creativity and technological innovation or high technology development. It offers us a new paradigm to look at economic phenomena from social and cultural perspectives. However, there is no theoretical and empirical study so far that proves a significant relationship between social 
and cultural diversity and existence of high tech clusters. Florida's research does not provide any convincing data that demonstrate the vibrant economy for his creative cities, nor has he provided any statistically significant proof for the correlations between his creativity factors and high tech clusters. In addition, cultural clashes and social diversity alone may not be enough to explain an economic phenomenon. Since high technology development is still an economic phenomenon, relevant economic and industrial characteristics should also be considered for high tech industrial location.

In addition to the four theories mentioned above, many researchers propose their own theories attempting to explain high tech economy. European scholars develop a milieu theory to explain innovation in a region. The milieu is a network system consisting of regional institutions, rules, and practices that provides its members with what they need for coordination and innovation. The milieu school contributes successful high technology development to the existence of milieu in a region. However, they could not specify the potential mechanisms and processes that milieu works and what is the economic logic of a milieu (Granovetter 1985, Aydalot 1986, Aydalot and Keeble 1988, Maillat, Crevoisier and Lecoq 1990, Camagni 1992). Another popular theory on high tech clusters is path dependency. This school states that local high tech development is path dependent and is truly historical. For instance, a historical event triggers generation of one or a few high tech firms, and this further attracts more high tech businesses moving 
in and more business services are developed to support these high tech businesses. In short, high tech clusters are built on accidental historical events (Arthur 1989). In addition to milieu theory and path dependency, there are also many other theories seeking to explain high technology economic growth, such as endogenous new growth theory (Romer 1986, DeLong and Summers 1991, Martin and Sunley 1998), the Schumpeterian endogenous innovation model (Romer 1990; Grossman and Helpman 1991; Aghion and Howitt 1993), Vernon's product life cycle theory (Vernon 1966), export base theory (North 1955, Perloff and Wingo 1961), Institutionalism (Amin 1999, Putnam, et al. 1993, Saxenian 1994), to name just a few. These theories are beyond the scope of this dissertation. 


\section{CHAPTER 3}

\section{LITERATURE REVIEW ON THE LOCATION OF HIGH TECH INDUSTRIES}

The previous chapter discusses four theories of high technology economic development. It gives us a theoretical background through which location patterns of high tech industries could be analyzed. This chapter reviews previous theoretical and empirical studies on the primary location factors that influence high tech industrial concentration, with an eye forward placing these factors into one or more of the four theoretical framework.

Since the 1980s, a growing number of studies have focused on the geographic distribution of high technology industries and the factors conditioning their spatial patterns. In High Tech America, Ann Markusen, Peter Hall, and Amy Glasmeier argue that four series of key factors have important impacts on the spatial distribution of high technology industries among the metropolitan areas: quality of life factors such as pleasant climate; access to transportation networks such as airport and freeway; agglomeration economies, e.g. the presence of corporate headquarters; and socio-political 
factors like federal defense spending (Markusen, Hall and Glasmeier 1986). The Milken Institute lists a range of factors in its research, America's High Tech Economy: Growth, Development, and Risks for Metropolitan Areas, which include an educated workforce, proximity of a top ranked research institution, presence of suppliers and business networks, production costs, existence of venture capital, tax incentives, commercialization of ideas, climate and other quality of life factors (DeVol 1999).

In the following section, this study will review these primary factors mentioned in the different streams of the literature on high tech economic development. These location factors can also be interpreted by the relevant theories discussed above, and are used to test the effectiveness of these theories in explaining high tech industrial concentrations in the later chapters. For instance, a well-educated labor force and top research institutions account for human capital theory; concentration of foreign-born population can be explained by creative cities theory; and reasonable production cost, such as low labor cost and access to transportation network, is a decisive factor for classical location theory. These primary location factors are detailed below:

\section{A young, well-educated labor force}

According to human capital theory, a knowledge-based labor force has become a prerequisite for high tech businesses. The success of any high tech enterprise depends on its ability to recruit and retain highly educated and skilled knowledge workers. In their 
theoretical and empirical research, many scholars point out that an educated labor force, or human capital, has become a decisive factor for high tech industrial location (Bartik 1991, Rauch 1993, Bradbury, Kodrzycki and Tannenwald 1997, Cohen 2000, Cortright 2001a, b, DeVol 1999, Glaeser and Shapiro 2001, Rondinelli 1998, Fulton and Shigley 2001, Simmer eds. 2002). Carton argues that a larger technical labor force significantly increases the births of new high tech firms in an MSA (Carton 1997). Frenkel demonstrates that the availability of skilled labor is an important location factor for high tech plants in Israel (Frenkel 2001). Antonelli (1990), Todtling (1992) and RodriguezPose (1999) find that innovation is associated with a young and well-educated labor force. Simmie, Sennett, Wood, and Hart list professional and skilled labor force and the learning systems as the most important considerations for high tech firms to choose a location (Simmie, Sennett, Wood, and Hart 2002). Rauch used both wage and rent gradients to explain how better educated people increase productivity. His model shows each additional year of SMSA average education can be expected to raise total productivity by 2.8 percent (Rauch 1993). Black and Lynch find that a 10 percent increase in average education in a firm increases productivity by 8.5 percent in manufacturing and 12.7 percent in non-manufacturing (Black and Lynch 1996). Bates states that firms with more educated workers survive the longest (Bates 1990). Cohen claims that education is one of the top reasons for a firm to choose a location (Cohen 2000). Milken Institute ranks an educated workforce as the top factor that determines where high tech is concentrated (DeVol 1999). In the Metropolitan New Economy Index, 
Atkinson and Gottlieb argue that the metropolitan area's success will be increasingly determined by education and skilled labor (Atkinson and Gottlieb 2001).

\section{Proximity to top-ranked Research Universities.}

Human capital theory states that investments in research and education have increasing returns to the productivity of both physical capital and the general labor force (Lucas 1988). According to this concept, world famous research institutions are considered to be the driving force for high tech innovation. For instance, the research centers and universities in Silicon Valley, Route 128, and North Carolina's Research Triangle enable cutting-edge research to be combined with local knowledge-intensive high tech firms in promoting and developing these high tech regions.

A wide variety of studies have identified the crucial role of top ranked research institutions in promoting high tech growth and production concentration (Dorfman 1983, Malecki 1986, Nelson 1986, Lund 1986, Rees and Stafford 1986, Vaughan and Pollard 1986, Rees and Stafford 1986, Harding 1989, Jaffe 1989, Luger \& Goldstein 1991, Mansfield 1991, Bania, Calkins and Dalenberg 1992, Parker and Zilberman 1993, Sivitanidou and Sivitanides 1995, Anselin, Varga and Acs 1997, Rondinelli 1998, DeVol 1999, Cohen 2000, Fulton and Shigley 2001). Rogers states that "money goes to the academic haves, not the have-nots" (Rogers 1986, p.177). Jaffe (1989) used a modified knowledge production function to measure the importance of geographic proximity to a 
research university, and found a significant positive impact of university research on corporate patents. He further states that university research induces industry $\mathrm{R} \& \mathrm{D}$, and thus improves local innovative activities. Jaffe was the first to offer some evidence for the importance of university research on high tech economic development, especially in drugs, chemicals, and electronics manufacturing (Jaffe 1989). Adams and Jaffe (1996) also identify that the productivity-enhancing effects of academic R\&D decline with distance, which supports the local knowledge spillover model. Castells suggests that top ranked research universities play a very important role on high tech clusters development in Boston and San Jose metropolitan areas (Castells 1989). Lee, Miller, Hancock, and Rowen document the role of Stanford University and other research institutions in Silicon Valley's high tech advantage (Lee, Miller, Hancock, and Rowen 2000). Acs, Audretsch and Feldman use innovation counts compiled from U.S. Small Business Administration and find strong evidence of a positive relationship between university research and innovation activities (Audretsch and Feldman 1996, Acs, Audretsch and Feldman 1994). Simmer's research on five European cities shows the importance of research universities as sources of information, knowledge providers, and innovation (Simmie, Sennett, Wood, and Hart 2002). Anselin, Varga and Acs find a positive relationship between university research and high tech innovative activities at the MSA level (Anselin, Varga and Acs 1997, Varga 2000). Zucker, Darby and Armstrong demonstrate the strong evidence of university research on biotech industries when university scientists are directly involved with local high tech firms through ownership or contractual ties (Zucker, Darby, and 
Armstrong 1994). Paytas, Gradeck, and Andrews argue that a university's research and development expenditures are strongly positively associated with growth rates of startups firms. They further claim that universities must have a large base of research and development to significantly influence cluster-based high tech economic development (Paytas, Gradeck, and Andrews 2004).

The importance of research universities to high tech economic development can be explained in two aspects. First, research universities are major producers of new knowledge. Basic research produces new scientific findings, which is often applied to practical applications in various high technology industries. In economic development, many scholars believe new industries invariably arise from scientific research nearby. Therefore, the importance of basic university research in the stimulation of technological development is defined by a wide range of research (Nelson 1959, Arrow 1962, Griliches 1979, 1990 and 1992, Nelson 1982, Von Hippel 1988, Dosi 1988, Cohen and Levinthal 1989, Acs and Audretsch 1990, Mansfield 1991, Florax 1992, Feldman 1994a, Goldberg 1999). Second, universities are not only producers of knowledge, but also producers of high-skilled technical professionals. The role of universities in the development of human capital that is more likely to create technological innovations and attract or generate high tech businesses is highlighted in the work of Bartel and Lichtenberg, Lucas and Malecki, among others (Bartel and Lichtenberg 1987, Lucas 1988, Malecki 1991). In short, 
research universities play a crucial role on high tech economic development in that they act as both producers of knowledge and producers of human capital.

On the other hand, Howells (1984), Markusen et al. (1986), Glasmeier (1991), Florax and Folmer (1992), Bania, Eberts and Fogarty (1993), and Beeson and Montgomery (1993) find little significant relationship between university research and innovative activities or high tech economic growth in a region. Malecki (1997, p. 269) and Feldman (1994b) suggest that the presence of a top research university does not necessarily lead to the development of a high tech center as in the case in Johns Hopkins University in Baltimore. Gray, Golob and Markusen could not find a significant influence of the University of Washington on the aerospace and software industry in the Seattle metropolitan region (Gray, Golob and Markusen 1996).

\section{Regional amenities and an attractive quality of life factors}

Many scholars consider quality of life factors such as climate, recreational opportunities, low crime rate, and a clean environment as key attributes for attracting and retaining an educated technology workforce (Markusen, Hall, and Glasmeier 1986, Blair and Premus 1987, Myers 1987, Taylor 1987, Gottlieb 1994, Gottlieb 1995, Segedy 1997, Goodstein 1999, Granger and Blomquist 1999, Fulton and Shigley 2001, Florida 2000, Simmie, Sennett, Wood and Hart, 2002). 
High tech employees are often very selective in where they would like to live and work. Companies must therefore go to where workers want to live. Locations that are attractive to knowledge workers are more likely to develop and maintain high technology industrial clusters. In other words, an environmentally attractive location (good climate, housing, public services, etc.) is essential for a firm to be able to hire the right person. Cohen argues that recreational activities, natural amenities, public safety and affordable housing were very attractive to draw educated workers in the late 1990s (Cohen 2000). Atkinson and Gottlieb claim that natural advantage such as a good weather and outdoor recreation opportunities has become a very important factor for high tech industrial location (Atkinson and Gottlieb 2001). Stafford ranked quality of life factors as third out of ten for high-tech firms in choice of region (Stafford 1983). Lund ranked quality of life as third out of six for high-tech R\$D facilities (Lund 1986). Wong found that high-tech firms rank quality of life factors higher than do traditional manufacturing industries (Wong 2001). Gottlieb suggested that environmental quality is an important quality of life factor for all kinds of firms. He further argues that cost of living, housing affordability and commuting issues have greater relative importance than cultural amenities, school quality, and public safety in terms of the location of high-tech businesses (Gottlieb 1994). Milken Institute identifies climate, general cost of living, and other quality of life factors as important elements for location considerations by high tech industries (DeVol 1999). Rondinelli states that cities or regions need to improve quality of life conditions such as the quality and diversity of cultural, artistic and recreational resources, environmental 
quality and physical security to attract and retain high tech businesses (Rondinelli 1998).

It should be noted that the concept of quality of life is ambiguous. Various studies drawn from literature review list many factors as quality of life factors, for example, environmental quality, recreational amenities, cultural opportunities, climate, affordable living costs, public safety, public education, museums and art galleries, to name just a few (Markusen, Hall, and Glasmeier 1986, Blair and Premus 1987, Myers 1987, Taylor 1987, Gottlieb 1994, Gottlieb 1995, Segedy 1997, Goodstein 1999, Granger and Blomquist 1999, Fulton and Shigley 2001, Florida 2000, Simmie, Sennett, Wood and Hart, 2002). Meanwhile, the term has a different meaning to people from different backgrounds. To an executive, it may indicate a large real estate in a gated community with world-class golf courses and a low property tax. To another person, it may mean a walkable community with sidewalks and bike paths and a high quality public school system. Therefore, it is difficult to measure the impact of quality of life factors on high tech professionals. Furthermore, some scholars state that spatial locations of high tech industries could not be explained by quality of life conditions in a region. For instance, high tech industries choose golden California beaches, but ignore the southern charm of New Orleans and the spectacularly beautiful Ozarks region (Castells 1989). On the other hand, educated people could change their environment and improve quality of life conditions after they settle down (Castells 1989). In this study, I adopt a reduced form model by selecting climate, crime rate, coastal location, and housing affordability to 
represent quality of life factors. A pleasant climate, public safety, and cost of living measured by housing affordability are frequently used factors in the majorities of quality of life studies (Gottlieb 1994, DeVol 1999, Cohen 2000, Atkinson and Gottlieb 2001). In addition, people like living close to the ocean or Great Lakes to enjoy beaches and sunshine. Coastal locations are associated with natural amenities and a variety of recreational opportunities, and are identified as an important quality of life factor in influencing high tech business locations.

\section{Agglomeration Economies.}

According to agglomeration economies theory, firms gain external effects through the existing cluster of relevant firms, the presence of a quality labor pool, shared infrastructure and access to input suppliers and potential buyers. Agglomeration economies overwhelm other factors and are considered as a determinant on the location decisions of high tech businesses (Cortright 2001b, Head, Ries and Swenson 1995). Porter states that "industry clusters" - geographic concentrations of inter-connected companies, produce competitive advantage (Porter 1990, 2000). Dumais, Ellison and Glaeser argue that industries with similar labor forces enjoy the highest profit by locating close to each other, indicating the importance of labor market pooling (Dumais, Ellison and Glaeser 1997). Haug proclaims that agglomeration economies play a significant role on high tech industrial concentration in the Washington state (Haug 1991). Henderson argues that industry-specific external economies increase due to the positive spillovers 
among businesses located nearby. This positive external impact declines with distance (Henderson 1974, 1977, and 1988). Malecki claims that labor market pooling and large number of specialized producers in a region help firms to minimize transaction costs (Malecki 1999). Wheeler and Mody (1992) and Smith and Florida (1994) argue that agglomeration economies are positively associated with corporate location decisions. Milken Institute states that agglomeration economies offer "critical mass to support a network of local suppliers, a highly specialized local labor market, and ... deep information spillovers" (DeVol 1999, p. 42).

\section{Reasonable production cost.}

It has long been recognized that production cost such as transportation cost can affect a firm's location decision. Though the technological revolution in information and telecommunication has dramatically decreased the importance of transportation costs and other production costs, many scholars argue that production cost is still a very important location factor for high tech industries. Ann Markusen, Peter Hall, and Amy Glasmeier list the access to a transportation network, such as a highway and an airport, as an important consideration for high tech industrial location (Rosenberg 1985, Markusen, Hall and Glasmeier 1986). Button suggests that major high technology establishments are usually within easy reach of airport facilities. Air transportation is important in virtually all high-tech location decisions (Button 1984). Cohen states that highway density has a positive impact on new manufacturing firm formation and total employment in a region 
(Cohen 2000). The research by the Milken Institute suggests that rising production costs push high tech manufacturing firms to lower-cost metropolitan areas such as the clusters of computer manufacturing in Austin, Dallas and Sacramento (DeVol 1999). McCann and Sheppard argue that spatial transaction costs actually have increased in some industries, especially in production sectors in which the demand lead-times have fallen dramatically (McCann and Sheppard 2003). Cortright proclaims that transportation costs are still important location factors for high tech firms (Cortright 2001b).

\section{Diversity and creative social environment.}

Led by Peter Hall's creative cities theory, some researchers identify a diversified and creative social environment as a crucial factor in promoting innovative high tech activities. Clinitz and Jacobs mention that regions with a diversity of knowledge sources are the breeding grounds for new ideas and creative thinking (Clinitz 1961, Jacobs 1969, 1984). Some scholars claim that culture diversity and openness to immigrants is a crucial factor in the Silicon Valley's success in the 1990s (Saxenian 1994, Micklethwait 1997, Lee, Miller, Hancock, and Rowen 2000). Florida states that metropolitan regions with a large percentage of foreign-born population rank at the top in terms of high tech industrial concentration (Florida 2001). Duranton and Puga developed a model that confirms that the diversity of regions stimulates firms' innovative experiments, and therefore, high tech industries are more likely to cluster in more diversified metropolitan areas (Duranton and Puga 1999). 
Do all of these factors mentioned from previous literature have deterministic impacts on locations of high tech industries? Are some factors more important than others in influencing high tech firms' location behaviors? This study explores various location factors mentioned from literature review, aiming at identifying the importance of these factors in influencing location decisions of high tech industries and further testing theories on their effectiveness in explaining high tech regional concentration. 


\section{CHAPTER 4}

\section{METHODOLOGY AND DATA}

High technology industries, led by a computer and information revolution, have demonstrated a spatial bias since their inception in the United States. This study builds upon the theories of high tech development to uncover the key variables affecting high technology economic growth in metropolitan areas. The purpose of this study is twofold:

- To understand the location pattern of the high technology economy and the primary factors that contribute to its spatial patterns; and

- To test human capital theory, agglomeration economies theory, Classical location theory, and creative cities theory for their effectiveness in explaining high technology industrial concentration

To explore the location preferences of high technology firms and the factors that influence them, the study develops spatial databases and maps showing the location of different types of high technology firms, and conducts statistical analyses to compare the role of primary factors in attracting or spawning high technology businesses. In Chapter 
5, I apply Geographic Information System (GIS) technologies as a tool to map location of high tech industries among the metropolitan areas. Only if we understand where high tech is concentrated, can we further study relevant theories and their impacts on high technology industrial concentration. The unit of study is the 316 census-defined Metropolitan Statistical Areas (MSAs), New England County Metropolitan Areas (NECMAs), or Primary Metropolitan Statistical Areas (PMSAs). These metropolitan areas use the names of the principal or largest cities in the metropolitan regions. ${ }^{1}$ These MSAs concentrate the majority of high tech employment nationally. In 1999, 93 percent of high-tech jobs were located in metropolitan regions, accounting for 7.1 million hightech jobs. This is not surprising, as metropolitan areas have a high concentration of information industries, such as computer software, real estate, finance, insurance, which require more advanced telecommunication networks and information systems. In addition, the social and institutional linkages bind together a region's residents and businesses, thus increasing the spillover of knowledge, stimulating technological innovation, and generating regional economic growth (Standard and Poor's DRI 2000).

As mentioned in Chapter 1, there are two popular definitions of high tech industries. One uses employment data by industrial sectors. County Business Patterns has employment data based on the North American Industry Classification System (NAICS)

\footnotetext{
${ }^{1}$ As defined by the United States Office of Management and Budget (OMB), an MSA is made up of at least one large city (50,000 population or more), and includes the county or counties in which it is located. Adjacent and other nearby counties meeting certain criteria are also included in the MSA.
} 
code since 1998. Another popular approach is to define high tech workers by occupation. BEA has data classified by occupation, including computer occupation, engineering and scientists. It has more accurate data on high tech professionals, but it does not classify them by industrial sectors. Because this study is not only interested in total high tech profile, but also interested in individual high tech sectors, I use industrial employment data from County Business Patterns in this dissertation.

The definition of high technology industries is based on the North American Industry Classification System (NAICS) code from the U.S. Census Bureau, which includes Pharmaceutical and Medicine Manufacturing (NAICS 3254), Computer and Electronic Product Manufacturing (NAICS 334), Aerospace Product and Parts Manufacturing (NAICS 3364), Medical Equipment and Supplies Manufacturing (NAICS 3391), Telecommunications (NAICS 5133), Information and Data Processing Services (NAICS 514), Computer Systems Design and Related Services (NAICS 5415), Architecture, Engineering and Related Services (NAICS 5413), Scientific R\&D Services (NAICS 5417), Software Publishers (NAICS 5112). These industries concentrate a higher proportion of scientists, engineers, and technology-related workers, and are identified as high tech industries in various studies (Ross 1999). Table 1 shows these industries, their NAICS codes and the relevant SIC codes. 
Table 1

NAICS and SIC Conversion

\begin{tabular}{|c|c|c|c|}
\hline & NAICS & & SIC \\
\hline 3254 & Pharmaceutical \& Medicine Manufacturing & 283 & Drugs \\
\hline \multirow[t]{4}{*}{334} & Computer \& Electronic Product & 357 & Computers and Office Equipment \\
\hline & \multirow[t]{3}{*}{ Manufacturing } & 366 & Communications Equipment \\
\hline & & 381 & Search and Navigation Equipment \\
\hline & & 382 & Measuring and Controlling Devices \\
\hline 3364 & Aerospace Product and Parts Manufacturing & 372,376 & Aerospace \\
\hline 3391 & $\begin{array}{l}\text { Medical Equipment and Supplies } \\
\text { Manufacturing }\end{array}$ & 384 & Medical Instruments and Supplies \\
\hline 5133 & Telecommunications & 481 & Telephone Communications \\
\hline 5112 & Software Publishers & & \\
\hline 514 & Information and Data Processing Services & & Computer and Data Processing \\
\hline 5415 & Computer Systems Design \& Related Services & 737 & Services \\
\hline 5413 & $\begin{array}{l}\text { Architectural, Engineering and Related } \\
\text { Services }\end{array}$ & 871 & $\begin{array}{l}\text { Engineering and Architecture } \\
\text { Services }\end{array}$ \\
\hline 5417 & Scientific R\&D Services & 873 & Research and Testing Services \\
\hline
\end{tabular}

Source: U.S. Census Bureau 2000

In Chapter 6, I will conduct multiple regression analyses to test the importance of primary factors mentioned from the literature on the location of high tech industries among the MSAs. After running the multiple regressions, I find that human capital variables show strong, positive correlations with dependent variables and its R-square is also high (see Table 2). This indicates that human capital variables have a stronger explanatory power than the variables representing the other three theories. Then, I choose two-block regressions with human capital variables in block 1 . In block 2 , I use variables representing Classical Location theory, Agglomeration Economies theory, and Creative Cities theory respectively. 
Table 2

R Squares of Multiple Regressions for Each Theory

\begin{tabular}{lc}
\hline Theories & R Squares \\
\hline Human Capital Theory & 0.445 \\
\hline Agglomeration Economies Theory & 0.243 \\
\hline Classical Location Theory & 0.340 \\
\hline Creative Cities Theory & 0.126 \\
\hline
\end{tabular}

Note: dependent variable is high tech employment change between 1998 and 2001;

independent variables are location factors representing human capital theory, agglomeration economies theory, classical location theory, and creative cities theory, respectively.

The analytical results will further test the theories on their effectiveness in explaining high tech spatial concentration. The dependent variables are total high tech employment in 2001 (log transformation is used to ensure its normal distribution) and the change of total employment for the ten high tech industries in each metropolitan area from 1998 to 2001. Data are from County Business Patterns, which provides data on the midMarch employment, and the total number of establishments by detailed industrial sectors for all Metropolitan Statistical Areas (MSAs) and New England County Metropolitan Areas (NECMAs).

From 1998 to 2001, the national high tech economy experienced dramatic changes. In 1998, an outpouring of capital financed many startup high tech firms, and accelerated the rapid growth of high tech service sectors. The booming of the Internet based 
applications and E-commerce reached its height in 1999. High tech firms, led by Internet and E-Commerce companies, attracted talent and the seeming endless supply of venture capital, which posed a great challenge to the traditionally operated companies. The hightech boom eventually gave way to the crash of the NASDAQ, the economic recession of 2001, and the numerous bankruptcies of dot-come business during 2000 and 2001, which marked a decline in the ability of the Internet and E-commerce to completely transform the economy (Zook 2001). The bursting of the dot-com bubble hit hard on some high tech sectors, such as Aerospace Products and Parts Manufacturing, and Computer Manufacturing, which observed substantial employment decreases between 1998 and 2001. However, as discussed in the next chapter, high tech service sectors, such as Information and Data Processing and Computer System Designs, still showed promising employment growth in the falling economy, suggesting the growing market demand for advanced high technology services.

In addition to the booming and bursting of the national economy, economic globalization has had a dramatic impact on the ways local firms do business. With improvements in transportation and communication technologies, cities and regions are now linked directly to the global market. The multinational corporations are forced to establish subsidiary operations in major host countries in order to compete in the international economic markets. The overseas expansion of multinational corporations has further developed a network of international economic and information transactions 
across the continents (Feagin and Smith 1987, Nahm and Semple 1993). The cities hosting these multinational corporations such as New York, London, and Tokyo, are global cities, which act as command centers in the organization of the world economy (Sassen 1991). The regions hosting these global cities are developing closed interdependencies with regions in other countries. Economic globalization brings new challenges and opportunities to local economies and high tech firms.

The independent variables are selected factors that have received the bulk of attention in the recent literature, which include education, research universities, quality of life factors, agglomeration economies, transportation, and diversity. The majority of independent variables are measured in 1998. Some data, such as age, are relatively static and do not observe big changes in a few years. I use data from the U.S. Census Bureau 2000. The following section details these independent variables.

\section{$\underline{\text { An educated labor force }}$}

Percentage of population over 25 years old with at least a bachelor degree (EDU). This variable has been extensively used as a human capital indicator in a wide variety of research (Barro 1992, Rauch 1993, Black and Lynch 1996, DeVol 1999, Cohen 2000, Atkinson and Gottlieb 2001). I expect a positive relationship between this variable and high tech spatial concentration. The data are from U.S. Census Bureau 2000. 
Science and engineering graduate students per 1,000 population (GRADUATE).

High tech industries concentrate a higher proportion of scientists, engineers, and technology-related workers. Science and engineering graduates are the direct labor force that will attract high tech firms. I expect it has a strong positive relationship with high tech spatial concentration in an MSA. The data are from Survey of Graduate Students and Postdoctorates in Science and Engineering from the National Science Foundation, Division of Science Resources Studies.

Percentage of population between 25 and 44 years old (AGE). This age group represents a young, innovative and creative labor force, an important indicator for human capital. I hypothesize that there is a positive relationship between people aged 25 to 44 years old and high tech employment change. The data are from the U.S. Census Bureau 2000.

\section{$\underline{\text { Proximity to top-ranked research universities }}$}

Academic research (URD). According to human capital theory, academic research should have a positive impact on local innovation and high tech development. Paytas, Gradeck, and Andrews (2004) argue that universities must have a large base of research and development to significantly influence cluster-based high tech economic development. This study uses research and development expenditures (\$) at local universities in 1998 to represent academic research. The data are from the National 
Science Foundation/SRS, Survey of Research and Development Expenditures at Universities and Colleges, 1998.

Number of top-ranked research universities in the metropolitan areas (UNIV). The presence of top ranked research universities is listed as a very important location factor for high tech industries in a wide range of studies. This study calculates the number of top fifty research universities ranked by doctorate programs in an MSA. The top fifty research universities are from U.S. News.com

$\underline{\text { Regional amenities and an attractive quality of life. }}$

Many scholars consider regional amenities and quality of life factors as key attributes for attracting and retaining educated workers, and further promoting high tech development in a region. Since quality of life is a composite variable incorporating many factors, I adopt a reduced form model by selecting housing affordability, climate, crime rate, and coastal location to represent quality of life condition in an MSA. These variables are frequently identified as important quality of life factors in attracting knowledge professionals, thus further attracting high tech firms into a region (Gottlieb 1994, DeVol 1999, Cohen 2000, Atkinson and Gottlieb 2001).

Housing affordability (HA). Housing affordability is a ratio of median housing value to median household income. It represents cost of living conditions in a metropolitan 
area. The higher the ratio, the less affordable housing is. Since low cost of living is associated with high tech clusters according to quality of life approach, I expect there is a negative relationship between housing affordability and high tech clusters. Median household income and median housing value are drawn from the U.S. Census Bureau 2000.

Climate (CLIMATE). A good climate is hypothesized to have a positive relationship with high tech growth according to quality of life approach (Markusen, Hall, and Glasmeier 1986). Places Rated Almanac has compiled a "climate" index based on average seasonal temperature variation, average annual number of days clear, average annual precipitation, average annual number of days below $32 \mathrm{~F}$ and over $90 \mathrm{~F}$, and other climate factors. This study uses the climate index from Places Rated Almanac to represent the pleasantness of regional climate.

Crime rates (CRIME). Public safety is considered as an important quality of life factor on the location of high tech businesses. High crime rate means the place is not safe to live and work. Therefore, I expect a negative relationship between crime rates and high tech employment change. Data are from FBI Uniform Crime Reports 1998.

Near coast or great lakes (COAST). Coastal location provides local residents excellent outdoor recreational opportunities, and is cited as an important quality of life 
factor in this study. It is a dummy variable for coastal location equal to 1 if a metropolitan area touches an ocean or any of the Great Lakes and 0 otherwise. I expect that coastal MSAs show more high tech concentration than non-coastal regions. Data are compiled from Census Bureau SMSA shape file and ESRI software.

\section{$\underline{\text { Agglomeration economies }}$}

Industry Density (ESTD). Though information revolution and technological development has dramatically decreased business transaction costs, some scholars argue that high tech economic activities still require physical proximity to suppliers, customers, competitors and other relevant firms. Industry density is the number of high tech establishments divided by total square miles in an MSA, which is used to represent industrial agglomeration in local high tech sectors. A positive relationship is expected from this factor. The numbers of high tech establishments in an MSA in 1998 are from County Business Patterns. The total square miles in an MSA are calculated from metropolitan shape file, which is downloaded from U.S. Census Bureau.

Presence of at least five Fortune 500 corporation headquarters in an MSA

(FORTUNE). The Fortune 500 corporate headquarters variable has been used to represent agglomerative economies in a wide range of theoretical and empirical studies, e.g. in High Tech America by Markusen, Hall and Glasmier (Howells 1984, Markusen, Hall and Glasmier 1986, Malecki 1980). Here, I use a dummy variable, at least five Fortune 500 
corporate headquarters present in an MSA, to estimate the impact of this variable on high tech concentration. A positive relationship between this variable and high tech employment change is expected in the analysis. Data are from 1998 Fortune magazine.

Presence of firms with employment over 500 (LARGE). Acs, Audretsch and Feldman among others argue that smaller firms tend to be more innovative and productive than large establishments (Acs, Audretsch and Feldman 1994, Audretsch, van Leeuwen, Menkveld and Thurik 2001). Rosenthal and Strange (1999) suggest that smaller firms attract more businesses to a region than do larger firms. Porter (1990) argues that small firms have competitive advantage over large firms to promote innovation and growth. $\mathrm{He}$ advocates the dynamic benefits of smaller firms over monopolies on innovation. Anselin, Varga and Acs found a negative relationship between the presence of large firms in an MSA and high tech innovation (Anselin, Varga and Acs 1997). On the other hand, Markusen argues that large firms can have significant contributions to regional economic development (Markusen 1986). In this study, I hypothesize that metropolitan regions dominated by the presence of large firms show less high tech activities compared to metropolitan areas with dominance of small firms. Data are from County Business Patterns 1998. 
$\underline{\text { Reasonable production cost }}$

Average salary per job (WAGE). According to Classical location theory, labor cost is one of the most important production costs that affect the location of a firm. The Milken Institute suggests that rising labor costs push high tech manufacturing firms to relatively low-cost metropolitan regions such as the clusters of computer manufacturing in Austin, Dallas, and Sacramento (DeVol 1999). This study uses average salary per job in 1998 to represent labor cost. A negative relationship is hypothesized between labor cost and high tech clusters. Data are from Regional Economic Information System, Bureau of Economic Analysis at U.S. Department of Commerce.

The number of International Airports (AIR) in an MSA. The technological revolution in information and telecommunication has dramatically decreased the transportation cost. Transit time has become more important than transportation cost. Accessibility to airport ensures managerial and technical professionals to move quickly from one place to another, and is considered as a very important factor for business location decisions (Button 1984, Rosenberg 1985, Markusen, Hall, and Glasmeier 1986, Simmie, Sennett, Wood, and Hart 2002). I expect this variable has positive relationship with high tech employment concentration in an MSA. Data are from US Department of Transportation.

Total mileage of highways in an MSA (HIGHWAY). Some scholars argue that access to transportation network especially highway is an important location factor for high tech 
industries. This study uses the total mileages of interstate highways in an MSA. Data are downloaded from U.S. Department of Transportation. I expect there is a positive relationship between total miles of highways in an MSA and high tech employment change between 1998 and 2001.

\section{Diversity and creative social environment.}

Foreign-born population entering USA from 1990 to March 2000 (FOREIGN). Sir Peter Hall's creative cities theory states that cities with young and new immigrants coming from different backgrounds with different cultural and social values are more creative, therefore are more attractive to high tech industries. This study uses the percentage of foreign-born population entering USA in the 1990s to represent the diversified social environment in the metropolitan areas. Data are from U.S. Census Bureau 2000.

Table 3 lists all of the independent variables and their data sources. 
Table 3

List of Independent Variables

\begin{tabular}{|c|c|c|c|}
\hline Theories & Variables & $\begin{array}{l}\text { Expected } \\
\text { Sign }\end{array}$ & Source \\
\hline \multirow[t]{5}{*}{ Human Capital } & $\begin{array}{l}\text { Percentage of population over } \\
25 \text { years old with at least } \\
\text { bachelor degree }\end{array}$ & + & U.S. Census Bureau 2000 \\
\hline & $\begin{array}{l}\text { Science and engineering } \\
\text { graduate students per } 1,000 \\
\text { population }\end{array}$ & + & $\begin{array}{l}\text { Survey of Graduate Students and } \\
\text { Postdoctorates in Science and } \\
\text { Engineering from National Science } \\
\text { Foundation } 1998\end{array}$ \\
\hline & $\begin{array}{l}\text { Percentage of population } \\
\text { between } 25 \text { and } 44 \text { years old }\end{array}$ & + & U.S. Census Bureau 2000 \\
\hline & $\begin{array}{l}\text { Number of top-ranked research } \\
\text { universities in an MSA }\end{array}$ & + & $\begin{array}{l}\text { usanews.com and Census Bureau } \\
\text { SMSA shape file }\end{array}$ \\
\hline & Academic research & + & $\begin{array}{l}\text { Survey of Research and } \\
\text { Development Expenditures at } \\
\text { Universities and Colleges from } \\
\text { National Science Foundation } 1998\end{array}$ \\
\hline \multirow[t]{4}{*}{ Quality of Life } & Housing affordability & - & $\begin{array}{l}\text { Calculated from U.S. Census Bureau } \\
2000\end{array}$ \\
\hline & Climate & + & Places Rated Almanac 2000 \\
\hline & Near coast or great lakes & + & $\begin{array}{l}\text { Compiled from Census Bureau } \\
\text { SMSA shape file }\end{array}$ \\
\hline & Crime rates & - & FBI Uniform Crime Reports 1998 \\
\hline \multirow[t]{3}{*}{$\begin{array}{l}\text { Agglomeration } \\
\text { Economies }\end{array}$} & Industry Density & + & $\begin{array}{l}\text { Calculated from County Business } \\
\text { Patterns } 1998 \text { and Census Bureau } \\
\text { SMSA shape file }\end{array}$ \\
\hline & $\begin{array}{l}\text { Presence of at least five Fortune } \\
500 \text { corporation headquarters in } \\
\text { an MSA }\end{array}$ & + & Fortune magazine, April 1998 \\
\hline & $\begin{array}{l}\text { Presence of firms with } \\
\text { employment over } 500\end{array}$ & - & $\begin{array}{l}\text { Calculated from County Business } \\
\text { Patterns } 1998\end{array}$ \\
\hline $\begin{array}{l}\text { Creative Cities } \\
\text { Theory }\end{array}$ & $\begin{array}{l}\text { Foreign-born population } \\
\text { entering USA from } 1990 \text { to } \\
\text { March } 2000\end{array}$ & + & U.S. Census Bureau 2000 \\
\hline \multirow[t]{3}{*}{$\begin{array}{l}\text { Classical } \\
\text { Location Theory }\end{array}$} & Average salary per job & - & $\begin{array}{l}\text { Regional Economic Information } \\
\text { System } 1998\end{array}$ \\
\hline & $\begin{array}{l}\text { Number of International } \\
\text { Airports }\end{array}$ & + & $\begin{array}{l}\text { FAA, U.S. Department of } \\
\text { Transportation }\end{array}$ \\
\hline & $\begin{array}{l}\text { Total mileage of highways in an } \\
\text { MSA }\end{array}$ & + & $\begin{array}{l}\text { Calculated from FAA, U.S. } \\
\text { Department of Transportation }\end{array}$ \\
\hline
\end{tabular}




\section{CHAPTER 5}

\section{WHERE ARE HIGH-TECH INDUSTRIES LOCATED?}

The first step in understanding the high-tech economy is to investigate the spatial distribution of high-tech industries. Unless we know where these high-tech activities are located, it is difficult to make informed statements about the effectiveness of relevant theories on explaining high-tech economic development. In this section, I explore the spatial distribution of high tech industries in the United States between 1998 and 2001. This is the latest NAICS industrial employment data available from the U.S. Census Bureau's County Business Patterns. The unit of this study is the 316 census-defined Metropolitan Statistical Areas (MSAs), New England County Metropolitan Areas (NECMAs), or Primary Metropolitan Statistical Areas (PMSAs). These metropolitan areas are referred to by the name of the principal or largest city in the metropolitan region.

\section{High-Tech Industries: Definition}

I define high-tech industries based on the categories identified by the Milken Institute's research, which include Pharmaceutical and Medicine Manufacturing (NAICS 
3254), Computer and Electronic Product Manufacturing (NAICS 334), Aerospace

Product and Parts Manufacturing (NAICS 3364), Medical Equipment and Supplies

Manufacturing (NAICS 3391), Telecommunications (NAICS 5133), Information and

Data Processing Services (NAICS 514), Computer Systems Design and Related Services

(NAICS 5415), Architecture, Engineering and Related Services (NAICS 5413), Scientific

R\&D Services (NAICS 5417), and Software Publishers (NAICS 5112). These industries

concentrate a higher proportion of scientists, engineers, and technology-related workers, and are identified as high tech industries in various studies (Ross 1999). Table 4 shows

the conversion between the NAICS and the SIC codes of these high-tech sectors.

\section{Table 4}

High Tech Definitions: NAICS and SIC Conversion

\begin{tabular}{|c|c|c|c|}
\hline & NAICS & & SIC \\
\hline 3254 & Pharmaceutical \& Medicine Manufacturing & 283 & Drugs \\
\hline \multirow[t]{4}{*}{334} & Computer \& Electronic Product & 357 & Computers and Office Equipment \\
\hline & Manufacturing & 366 & Communications Equipment \\
\hline & & 381 & Search and Navigation Equipment \\
\hline & & 382 & Measuring and Controlling Devices \\
\hline 3364 & Aerospace Product and Parts Manufacturing & 372,376 & Aerospace \\
\hline 3391 & $\begin{array}{l}\text { Medical Equipment and Supplies } \\
\text { Manufacturing }\end{array}$ & 384 & Medical Instruments and Supplies \\
\hline 5133 & Telecommunications & 481 & Telephone Communications \\
\hline 5112 & Software Publishers & \multirow{3}{*}{737} & \multirow{3}{*}{$\begin{array}{l}\text { Computer and Data Processing } \\
\text { Services }\end{array}$} \\
\hline 514 & Information and Data Processing Services & & \\
\hline 5415 & $\begin{array}{l}\text { Computer Systems Design \& Related } \\
\text { Services }\end{array}$ & & \\
\hline 5413 & $\begin{array}{l}\text { Architectural, Engineering and Related } \\
\text { Services }\end{array}$ & 871 & $\begin{array}{l}\text { Engineering and Architecture } \\
\text { Services }\end{array}$ \\
\hline 5417 & Scientific R\&D Services & 873 & Research and Testing Services \\
\hline
\end{tabular}

Source: U.S. Census Bureau 2002 
These ten high-tech industries employed 7.7 million workers, or 6.7 percent of total

American workers in 2001. From 1998 to 2001, high-tech industrial employment

increased 13.7 percent, compared with 6.4 percent increase for the national economy as a

whole. This also accounts for almost 13.3 percent of total employment growth nationally.

High tech sectors are fast growing industries with substantial job creation in these years.

\section{Table 5}

$\underline{\text { High-Tech Industries Profiles }}$

\begin{tabular}{|r|r|r|r|r|r|r|}
\hline High-tech industries & \multicolumn{3}{|c|}{ Employment } & \multicolumn{3}{|c|}{ Establishment } \\
\cline { 2 - 7 } & 2001 & 1998 & $\begin{array}{r}\text { Percent } \\
\text { Change }\end{array}$ & 2001 & $\begin{array}{r}1998 \\
\text { Percent } \\
\text { Change }\end{array}$ \\
\hline Pharmaceutical \& Medicine & 233,503 & 217,111 & $7.55 \%$ & 1,825 & 1,812 & $0.72 \%$ \\
\hline Computer \& Electronic Product & $1,593,307$ & $1,680,833$ & $-5.21 \%$ & 16,764 & 17,625 & $-4.89 \%$ \\
\hline Aerospace Product and Parts & 449,383 & 518,874 & $-13.39 \%$ & 1,792 & 1,825 & $-1.81 \%$ \\
\hline Medical Equipment and Supplies & 304,435 & 295,914 & $2.88 \%$ & 12,151 & 12,469 & $-2.55 \%$ \\
\hline Telecommunications & $1,262,183$ & $1,040,978$ & $21.25 \%$ & 43,749 & 33,748 & $29.63 \%$ \\
\hline Information and Data Processing & 579,609 & 386,486 & $49.97 \%$ & 22,725 & 16,768 & $35.53 \%$ \\
\hline Computer System Design \& & $1,254,805$ & 873,270 & $43.69 \%$ & 100,852 & 85,356 & $18.15 \%$ \\
Related Services & & & & & & 102,692 \\
\hline Architectural, Engineering \& & $1,285,927$ & $1,171,410$ & $9.78 \%$ & 103,597 & $10.88 \%$ \\
Related Services & & & & & & \\
\hline Scientific R\&D Services & 387,067 & 309,848 & $24.92 \%$ & 13,514 & 11,685 & $15.65 \%$ \\
\hline Software Publishers & 353,344 & 283,182 & $24.78 \%$ & 10,353 & 11,689 & $-11.43 \%$ \\
\hline Total High-Tech & $7,705,564$ & $6,777,906$ & $13.69 \%$ & 327,322 & 295,669 & $10.71 \%$ \\
\hline
\end{tabular}

Source: data calculate from County Business Patterns, U.S. Census Bureau

Table 5 details total employment and establishments for high tech sectors. The four high tech manufacturing industries show slow or negative employment growth between 1998 and 2001. Aerospace Product and Parts Manufacturing lost over 13 percent workers from 1998 to 2001. Computer and Electronic Product Manufacturing employment lost 
almost ninety thousand workers, or over 5 percent of its labor force, nationally, and almost 5 percent of establishments during the same period. Pharmaceutical and Medicine Manufacturing had a better job growth rate compared to other high tech manufacturing sectors. During the same period, its employment increased by over 7 percent, higher than the national average (6.4 percent).

High tech service sectors experienced a high employment growth rate, an average of 25 percent, almost four times as fast as the national employment from 1998 to 2001 . The Information and Data Processing industry experienced nearly 50 percent employment increase, followed by Computer System Design and Related Services, 44 percent, Scientific R\&D Services, 25 percent, Software Publishers, 25 percent, and telecommunications, 21 percent. Architectural, Engineering and Related service has a slow job growth rate compared to other service sectors with 114,517 employments gain, or almost 10 percent increase. One interesting observation is among Software Publishers. This industry shows both employment growth (25 percent increase) and significant establishments loss (11 percent decline) from 1998 to 2001. It indicates that software publishers are continuingly consolidating their production functions to a few large software companies, showing the monopolistic competition in this high tech sector. 


\section{Inter-Metropolitan Distribution of High-Tech Industries}

High tech industries tend to choose certain places including both traditional high tech poles and new high tech centers, and observe substantial geographic imbalance across the MSAs. Figure 1 shows the geographic distribution of high tech employment by MSAs in 2001. High tech employment is highly concentrated on the Atlantic and Pacific coast, especially in California and the Northeaster Corridor (Washington - Boston), and the major metropolitan areas of Florida, Texas and the Midwest (Figure 1).

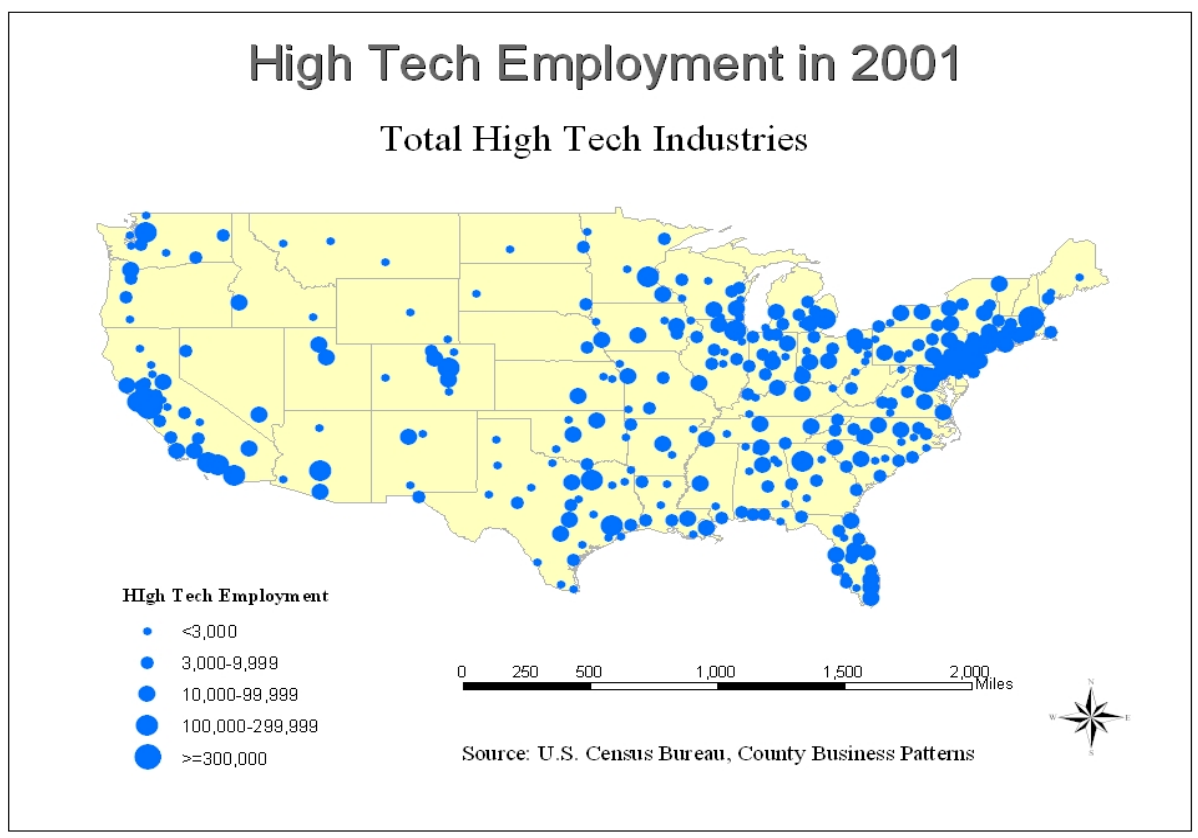

Figure 1: Spatial Distribution of High Tech Employment, 2001 


\section{Table 6}

Top 20 High Tech Metropolitan Areas in 2001

\begin{tabular}{rrr}
\hline Rank & Metropolitan Areas & High-Tech Employment 2001 \\
\hline 1 & Boston & 400,524 \\
2 & Washington, DC & 357,200 \\
3 & San Jose, CA & 310,574 \\
4 & Los Angeles & 279,352 \\
5 & Chicago & 272,688 \\
6 & Seattle & 241,250 \\
7 & Dallas & 219,087 \\
8 & Atlanta & 200,291 \\
9 & New York & 186,468 \\
10 & Philadelphia & 161,568 \\
11 & Orange County, CA & 151,227 \\
12 & Minneapolis & 137,503 \\
13 & Phoenix & 133,500 \\
14 & San Diego & 130,992 \\
15 & San Francisco & 130,878 \\
16 & Houston & 123,186 \\
17 & Denver & 117,946 \\
18 & Oakland & 115,736 \\
19 & Detroit & 102,200 \\
20 & Raleigh & 92,139 \\
\hline
\end{tabular}

Source: data calculated from County Business Patterns, U.S. Census Bureau

Table 6 shows the top twenty high tech metropolitan areas in terms of industrial employment in 2001. Boston ranks on the top with over four hundred thousand high tech employees in 2001. Washington D.C. is the second, followed by San Jose, Los Angeles, Chicago, Seattle, Dallas, Atlanta and New York. These high tech metropolitan areas have over half of national high-tech employment, and represented 43 percent of high-tech establishments in 2001. Again, these data indicate that high tech industries are highly concentrated. 


\section{High Tech Employment Change: 1998-2001}

Total High Tech Industries

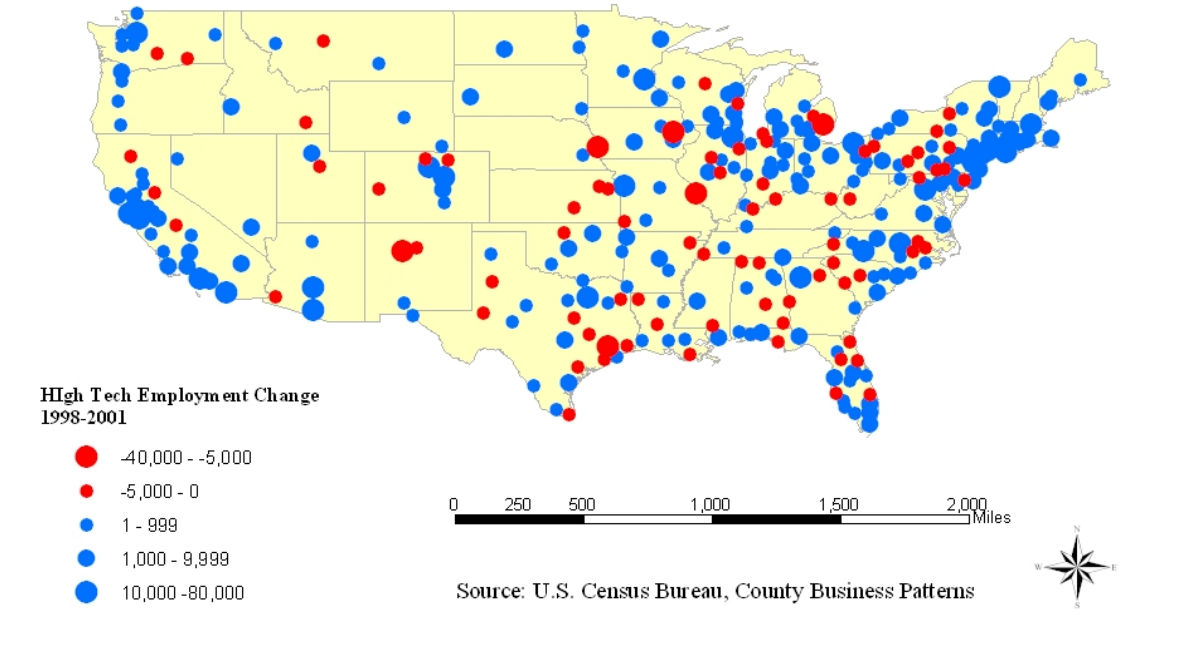

Figure 2: High Tech Employment Change, 1998-2001

Between 1998 and 2001, the majority of high tech employment growth occurred in the metropolitan areas of California, the Northeastern Corridor (Washington - Boston) and some regional high tech centers such as Atlanta, Seattle, Dallas, Kansas City, Phoenix, Minneapolis, Chicago, Raleigh, Denver and Boulder. Boston added 77,280 high tech workers from 1998 to 2001, ranking at the top on job gains. Washington D.C. is the second gainer with over 60,000 new high tech workers, followed by Atlanta, Seattle, San Francisco, and New York. Among the top twenty high tech job-gain metropolitan regions, fifteen of them are also in the top twenty MSAs on total high tech employment in 1998. This indicates that high tech growth occurs in large high tech regions. Kansas City, 
Middlesex, Nassau, and Boulder also experienced substantial employment growth, showing the emergence of new high tech centers in recent years.

\section{Table 7}

Top 20 High Tech Gain and Loss Metropolitan Areas

\begin{tabular}{rrrrr}
\hline & Metropolitan & Jobs Gains & Jobs Loss \\
Rank & Regions & $1998-2001$ & Metropolitan Regions & $1998-2001$ \\
\hline 1 & Boston & 77,280 & St. Louis & $-36,853$ \\
2 & Washington, DC & 60,861 & Albuquerque & $-23,511$ \\
3 & Atlanta & 46,226 & Houston & $-15,776$ \\
4 & Seattle & 44,950 & Detroit & $-9,049$ \\
5 & San Francisco & 38,272 & Omaha & $-7,872$ \\
6 & New York & 33,062 & Cedar Rapids, IA & $-5,925$ \\
7 & San Jose & 32,361 & Columbia, SC & $-4,102$ \\
8 & Dallas & 25,393 & Fresno, CA & $-2,232$ \\
9 & Kansas City & 23,348 & Richland, WA & $-1,984$ \\
10 & Phoenix--Mesa & 23,097 & Jacksonville, FL & $-1,896$ \\
11 & Minneapolis & 21,295 & Flint, MI & $-1,822$ \\
12 & San Diego & 20,438 & Memphis & $-1,715$ \\
13 & Oakland & 18,696 & Greenville, SC & $-1,393$ \\
14 & Chicago & 14,833 & Philadelphia & $-1,308$ \\
15 & Middlesex, NJ & 14,822 & Wichita, KS & $-1,273$ \\
& & & & \\
16 & Nassau & 14,370 & Bryan--College Station, TX & $-1,264$ \\
17 & Los Angeles & 14,074 & Sacramento & $-1,126$ \\
18 & Raleigh & 13,633 & Longview--Marshall, TX & $-1,036$ \\
19 & Boulder & 13,467 & Greeley, CO & -950 \\
20 & Denver & 13,436 & Shreveport--Bossier City, LA & -945 \\
\hline
\end{tabular}

Source: data calculated from County Business Patterns, U.S. Census Bureau

St. Louis leads the way in losing high tech employment. From 1998 to 2001, it lost over one-third of high-tech employment, or a net loss of 36,853 high-tech workers. Albuquerque is the second loser with over 23,000 high tech employment losses. Houston and Detroit also observed high tech employment declines. Between 1998 and 2001, 
Houston lost 15,766 high tech workers, and Detroit lost 9,049 high tech employment.

\section{Table 8}

$\underline{\text { Ranks for Top High Tech Metropolitan Regions in 1998, } 2001}$

\begin{tabular}{|c|c|c|}
\hline Rank & High-tech Employment, 1998 & Boston \\
\hline 1 & Washington, DC & High-tech Employment, 2001 \\
\hline 2 & San Jose & Boston \\
\hline 3 & Los Angeles & San Jose \\
\hline 4 & Chicago & Los Angeles \\
\hline 5 & Seattle & Chicago \\
\hline 6 & Dallas & Seattle \\
\hline 7 & Philadelphia \\
\hline 8 & Atlanta \\
\hline 9 & New York \\
\hline 10 & Orange County \\
\hline 11 & Houston \\
\hline 12 & Minneapolis \\
\hline 13 & Detroit \\
\hline 14 & San Diego \\
\hline 15 & Phoenix \\
\hline 16 & St. Louis \\
\hline 17 & Denver \\
\hline 18 & Oakland \\
\hline 19 & San Francisco \\
\hline 20 & 22 - Raleigh \\
\hline & \\
\hline
\end{tabular}

Source: Calculate from County Business Patterns, U.S. Census Bureau

Another way to look at spatial change of high tech industries is to compare their ranking hierarchy. The ranks for the first twenty MSAs in terms of high tech employment in 2001 are very similar to those in 1998 . The first seven metropolitan regions remain the 
same in the ranking hierarchy. Phoenix and San Francisco rose at least three positions, while Houston, Detroit, Philadelphia, and St. Louis experienced ranking declines. St. Louis dropped out of the top twenty.

\section{Spatial Allocation of High Tech Industries by Industrial Sectors}

High tech industries vary by their institutional and technological characteristics. For instance, Aerospace and Parts Manufacturing is an established science with a large share of federal funding. Pharmaceutical and Medicine Manufacturing is relatively new and more university driven. Given the differences among these industries in terms of knowledge creation, maturation, and the institutional context, I expect they will show

differences and similarities in their geographies. In other words, the level and pattern of spatial concentration vary considerably across high tech industries. 


\section{Table 9}

Top Ten Metropolitan Areas by High Tech Sectors, 2001

\begin{tabular}{|c|c|c|c|c|}
\hline \multirow[b]{2}{*}{ High-Tech Industries } & \multicolumn{2}{|c|}{ Employment } & \multicolumn{2}{|c|}{ Establishment } \\
\hline & Top 10 Metros & Percent & Top 10 Metros & Percent \\
\hline Pharmaceutical \& Medicine Manufacturing (3254) & 96,764 & $41 \%$ & 527 & $29 \%$ \\
\hline $\begin{array}{r}\text { Computer \& Electronic Product Manufacturing } \\
(334)\end{array}$ & 643,714 & $40 \%$ & 5,982 & $36 \%$ \\
\hline Aerospace Product and Parts Manufacturing (3364) & 274,849 & $61 \%$ & 641 & $36 \%$ \\
\hline $\begin{array}{r}\text { Medical Equipment and Supplies Manufacturing } \\
\text { (3391) }\end{array}$ & 90,111 & $30 \%$ & 2,766 & $23 \%$ \\
\hline Telecommunications (5133) & 408,678 & $32 \%$ & 9,660 & $22 \%$ \\
\hline Information and Data Processing Services (514) & 253,137 & $44 \%$ & 6,762 & $30 \%$ \\
\hline $\begin{array}{r}\text { Computer Systems Design \& Related Services } \\
(5415) \\
\end{array}$ & 516,623 & $41 \%$ & 35,833 & $36 \%$ \\
\hline $\begin{array}{r}\text { Architectural, Engineering and Related Services } \\
(5413)\end{array}$ & 392,215 & $31 \%$ & 24,317 & $23 \%$ \\
\hline Scientific R\&D Services (5417) & 199,040 & $51 \%$ & 4,879 & $36 \%$ \\
\hline Software Publishers (5112) & 202,348 & $57 \%$ & 3,724 & $36 \%$ \\
\hline TOTAL HIGH-TECH INDUSTRIES & $2,629,002$ & $34 \%$ & 89,707 & $27 \%$ \\
\hline
\end{tabular}

Source: data calculate from County Business Patterns 2001, U.S. Census Bureau

Table 9 details total employment and total establishments for the top ten metropolitan areas classified by industrial sectors. For all high tech industries, top ten metropolitan areas account for thirty-four percent of employment and more than twenty-five percent of establishments. Aerospace Product and Parts Manufacturing is the most concentrated industry with over sixty percent of employment and more than one-third of firms located in ten metropolitan regions in 2001. The largest region, Seattle, contributes to about onesixth of total aerospace manufacturing employees. The top three regions, Seattle, Los Angeles and Wichita, represented thirty-seven percent of total aerospace workers. It is easy to understand that economies of scale are very important for guided missiles, space 
vehicles and other aerospace products. The next concentrated industry is Software Publishers. Its fifty-seven percent of employment and thirty-six percent of businesses are located in the top ten metropolitan areas in 2001. Scientific R\&D industry is another high tech sector with over half of its employment locating in ten metropolitan regions. On the other hand, Medical Equipment and Suppliers Manufacturing, Architecture, Engineering and Related Services, and Telecommunications are relatively spread out compared to other high tech industrial sectors.

Another measurement on industrial concentration is a spatial Gini coefficient. Audretsch and Feldman (1996) use this index and prove that industries that emphasize research and innovation are more spatially concentrated. Krugman and many other scholars also use spatial Gini coefficients to measure geographic concentration (Krugman 1991b). The spatial Gini coefficient is calculated as follows:

$$
\mathrm{G}=\sum_{\mathrm{i}}\left(\mathrm{E}_{\mathrm{j}} / \mathrm{E}_{\mathrm{us}}-\mathrm{E}_{\mathrm{ij}} / \mathrm{E}_{\mathrm{ius}}\right)^{2}
$$

$\mathrm{E}_{\mathrm{j}}$ is the total employment in the metropolitan area $j . \mathrm{E}_{\mathrm{us}}$ is the total employment in the United States. $E_{\mathrm{ij}}$ is the total employment for industry $i$ in the metropolitan area $j . E_{\mathrm{ius}}$ is the total employment for industry $i$ in the United States. When the Gini coefficient equals to zero, an industry is distributed across space in the same way as for total employment. 
When the Gini coefficient closes to one (depending on industry size), the industry is completely concentrated in one location.

\section{Table 10}

Spatial Gini Coefficients for High-Tech Industries

\begin{tabular}{|l|r|r|}
\hline High-Tech Industries & 1998 & 2001 \\
\hline Pharmaceutical \& Medicine Manufacturing (3254) & .0128 & .0133 \\
\hline Computer \& Electronic Product Manufacturing (334) & .0138 & .0118 \\
\hline Aerospace Product and Parts Manufacturing (3364) & .0471 & .0476 \\
\hline Medical Equipment and Supplies Manufacturing (3391) & .0056 & .0054 \\
\hline Software Publishers (5112) & .0242 & .0266 \\
\hline Information and Data Processing Services (514) & .0031 & .0039 \\
\hline Telecommunications (5133) & .0087 & .0078 \\
\hline Architectural, Engineering and Related Services (5413) & .0053 & .0022 \\
\hline Computer Systems Design \& Related Services (5415) & .0080 & .0116 \\
\hline Scientific R\&D Services (5417) & .0219 & .0214 \\
\hline
\end{tabular}

Source: data calculate from County Business Patterns, U.S. Census Bureau

Table 10 shows Gini coefficients for each high tech sector in 1998 and 2001. Same as previous analyses, Aerospace Product and Parts Manufacturing ranks at the top with Gini coefficient at 0.047 , followed by Software Publishers and Scientific R\&D Services, 0.027 and 0.021 in 2001 respectively. It indicates that these three sectors are more spatially concentrated than other high-tech sectors. During the same period, Architectural, Engineering and Related Services, Information and Data Processing Services, Medical Equipment and Supplies Manufacturing, and Telecommunications industries have spatial Gini Coefficients lower than 0.01, showing their spread-out spatial patterns among the 
U.S. metropolitan regions. Some high-tech sectors such as Medical Equipment and Supplies Manufacturing did not experience much change on their Gini coefficients between 1998 and 2001. On the other hand, the spatial Gini coefficient for Architectural, Engineering and Related Services declined over half in just three years. Computer and Electronic Product Manufacturing also experienced obvious Gini coefficient decline during the same period. At the same time, Software Publishers and Computer Systems Design and Related Services observed dramatic Gini coefficients increases between 1998 and 2001. Though three-year range is relatively short to observe obvious spatial migration for an individual high tech sector, the dramatic changes on spatial Gini coefficients still show the trend that some industries are decentralizing, while others are continuing to concentrate across the United States.

\section{Pharmaceutical and Medicine Manufacturing (NAICS 3254)}

The Pharmaceutical and Medicine Manufacturing industry is a new, fast growing sector with dramatic change in the recent decade. From 1998 to 2001, it added 8 percent employees nationally, and was the only high tech manufacturing sector with both employment gains and establishment growth. This industry also enjoys high profitability, with the 17-year patent protection for its new products invention. The high corporate R\&D requirements and marketing costs have contributed to consolidation within the industry, thus leading to a concentrated spatial pattern. The top ten MSAs represent more than forty percent of industrial employment and over one-quarter of establishments 
nationally.

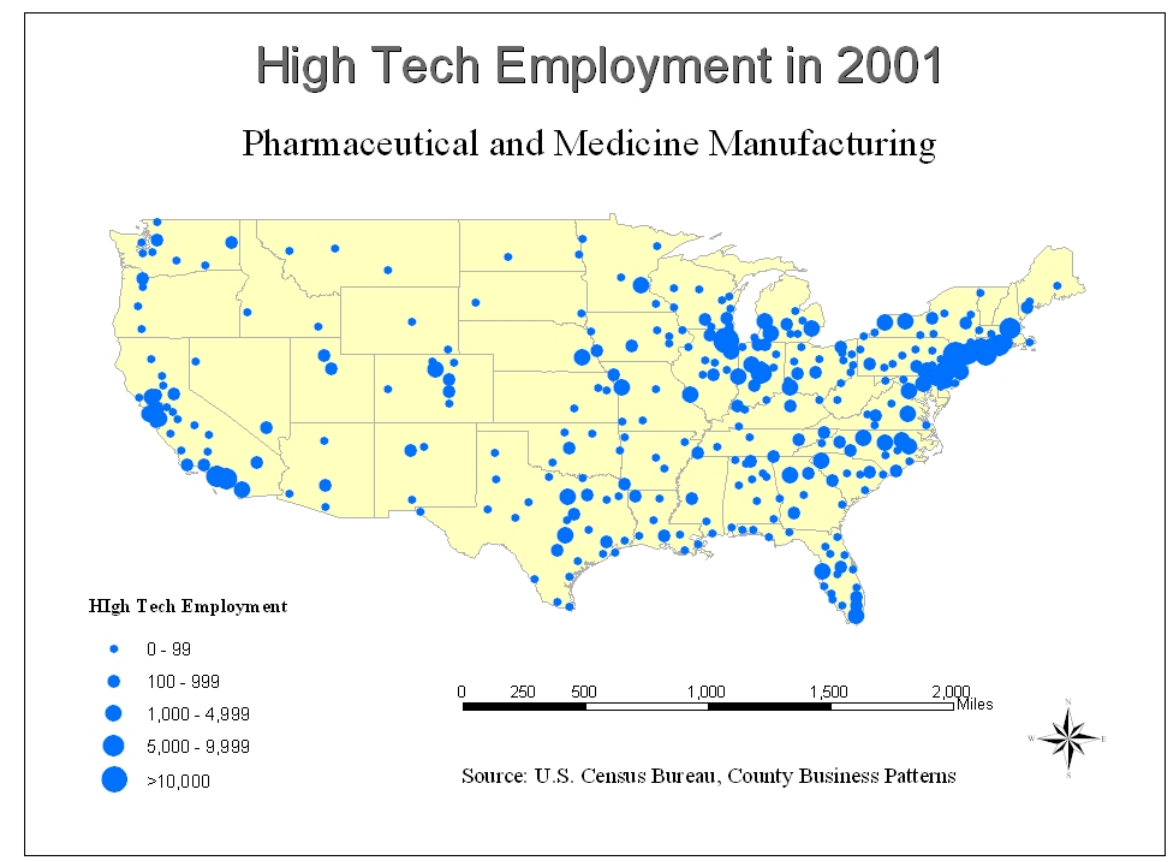

Figure 3 Spatial Allocations of Pharmaceutical and Medicine Manufacturing, 2001

The Pharmaceutical and Medicine Manufacturing industry concentrates in the Northeastern Corridor (Washington-Boston), the Midwest, and California (Figure 3). Chicago and Newark lead the industry's employment, with 17,500 pharmaceutical and medicine workers in 2001, followed by Philadelphia $(9,958)$, Boston $(7,500)$, New Haven $(7,500)$, Middlesex (7,500), Indianapolis $(7,500)$, New London $(7,500)$, Nassau $(7,489)$ and Los Angeles $(6,817)$ (see Table 11). These ten metropolitan areas account for over 40 percent of their industry's employment nationally. 


\section{Table 11}

Pharmaceutical and Medicine Manufacturing (NAICS 3254)

\begin{tabular}{rrrrrr}
\hline & Employment & Jobs Gains & Motro & 1998-2001 \\
\hline Metro & 2001 & Metro 1998-2001 & 3,750 & Fort Worth, TX & $-2,473$ \\
Chicago & 17,500 & New London & 3,750 & Kansas City & $-2,000$ \\
Newark & 17,500 & New Haven & 3,000 \\
Philadelphia & 9,958 & Indianapolis & 3,750 & Phoenix & $-1,000$ \\
Boston & 7,500 & Philadelphia & 2,458 & Columbus & $-1,000$ \\
New Haven & 7,500 & Baltimore & 2,000 & Salt Lake City & $-1,000$ \\
Middlesex & 7,500 & Nassau, NY & 1,557 & Syracuse & $-1,000$ \\
Indianapolis & 7,500 & Atlanta & 1,000 & New York & -989 \\
New London & 7,500 & Orlando & 740 & St. Louis & -984 \\
Nassau & 7,489 & Los Angeles & 571 & San Antonio & -575 \\
Los Angeles & 6,817 & Huntsville & 495 & Provo--Orem, UT & -455 \\
\hline
\end{tabular}

Source: Data Calculate from County Business Patterns, 2000, U.S. Census Bureau

According to Table 11, the majorities of employment growth occurred in Northeast and Midwest for this sector. Between 1998 and 2001, New London, New Haven and Indianapolis each added 3,750 pharmaceutical and medicine manufacturing jobs. Philadelphia, Baltimore, Nassau, and Atlanta also observed substantial employment growth. On the other hand, Fort Worth, TX lost over two thousand workers in pharmaceutical and medicine manufacturing during the same period, followed by Kansas City, Phoenix, Columbus, Salt Lake City and Syracuse. This indicates that pharmaceutical and medicine manufacturing industry continues to consolidate production facilities in the top MSAs to reduce costs and investment risks. 


\section{Computer and Electronic Product Manufacturing (NAICS 334)}

The Computer and Electronic Product Manufacturing industry initiates the information revolution and provides the technical base that propels the entire high tech industrial development. It has been at the top of industry growth over the past three decades. However, there has been intensified competitions within the industry as technological development greatly improves processing capabilities, which force US firms to move their production into developing countries, especially Asian, to lower production costs and access global markets. From 1998 to 2001, this industry lost 87,526 workers, or over 5 percent of its workforce, and almost 5 percent of establishments nationally.

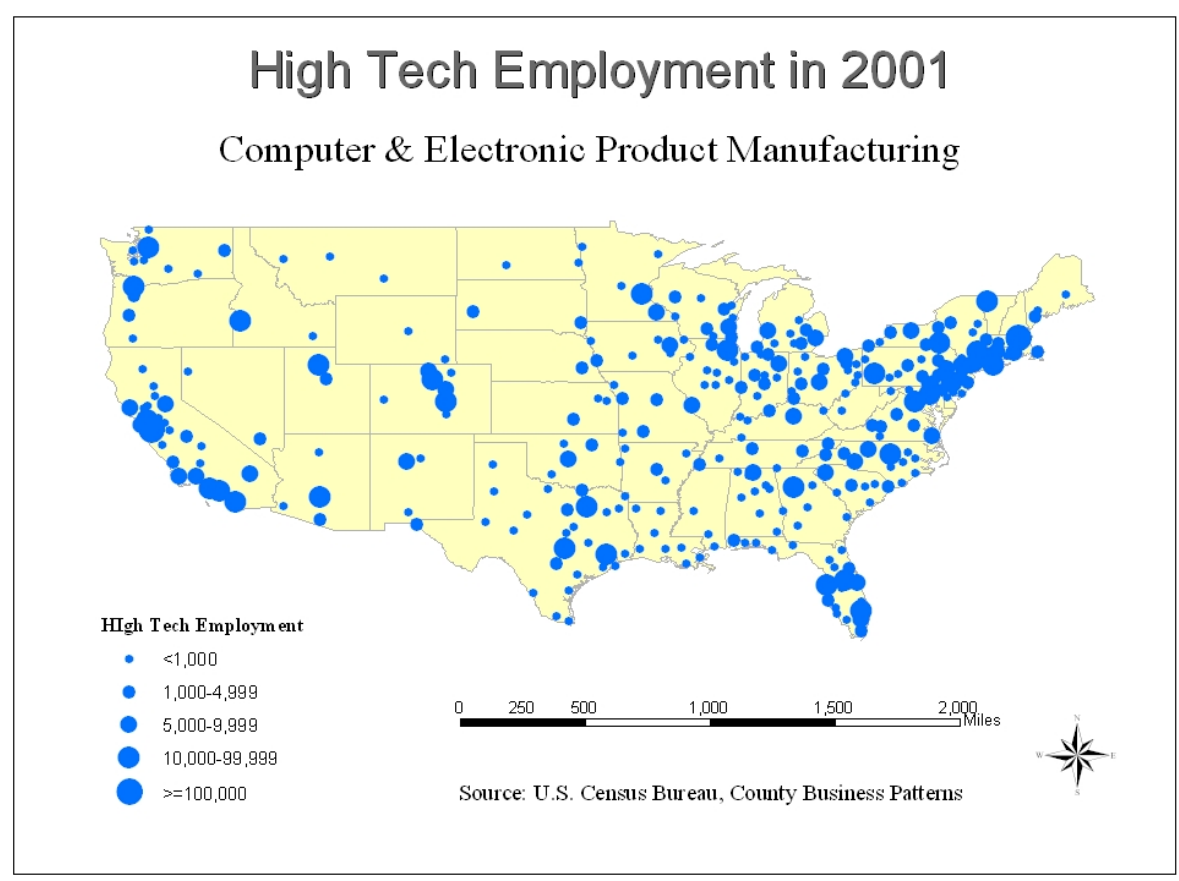

Figure 4: Spatial Allocations of Computer and Electronic Product Manufacturing in 2001 
The Computer and Electronic Product Manufacturing industry is especially concentrated in the Northeastern Corridor (Washington-Boston), California, and major high tech centers such as Chicago, Austin, Minneapolis, Phoenix, Portland, Raleigh and Seattle. Boston and San Jose are the largest computer and electronic product manufacturing metropolitan regions with over one hundred thousand employment in 2001, followed by Chicago, Dallas, and Los Angeles. The first ten metropolitan areas represent over forty percent of employment and more than one-third of establishments in this sector.

\section{Table 12}

Computer \& Electronic Product Manufacturing (NAICS 334)

\begin{tabular}{rrrrrr}
\hline \multicolumn{2}{c}{ Employment } & & Jobs Gains & Jobs Loss \\
Metro & 2001 & Metro & $1998-2001$ & Metro $1998-2001$ \\
\hline Boston & 120,314 & Burlington, VT & 10,000 & San Jose & $-39,223$ \\
San Jose & 119,350 Dutchess County, NY & 9,479 & Philadelphia & $-20,000$ \\
Chicago & 75,000 & West Palm Beach & 5,224 & Sacramento & $-10,948$ \\
Dallas & 70,346 & Salt Lake, UT & 3,792 & Cedar Rapids, IA & $-10,000$ \\
\multicolumn{5}{c}{ Allentown-- } \\
Lethlehem--Easton, \\
Los Angeles & 61,846 & PA & 3,750 & Detroit & $-10,000$ \\
Orange County & 46,858 & Grand Rapids, MI & 3,750 & Albuquerque & $-10,000$ \\
Austin & 37,500 & Dallas & 3,249 & Nassau, NY & $-5,747$ \\
Minneapolis & 37,500 & Boston & 2,010 & Phoenix & $-5,099$ \\
Phoenix & 37,500 & San Antonio & 2,000 & Syracuse & $-3,750$ \\
Portland & 37,500 & Myrtle Beach, SC & 2,000 & Kansas City & $-3,750$ \\
\multicolumn{5}{c}{ Appleton--Oshkosh-- } \\
Raleigh & 37,500 & Neenah, WI & 2,000 & Fort Worth, TX & $-3,750$ \\
Seattle & 37,500 & Omaha, NE--IA & 2,000 & & \\
\hline \multicolumn{5}{c}{}
\end{tabular}

Source: Data Calculate from County Business Patterns, 2000, U.S. Census Bureau 
Burlington, VT ranks at the top on employment growth. Between 1998 and 2001, Burlington gained over 10,000 new jobs in this sector. Dutchess County added almost ten thousand computer and electronic manufacturing workers, ranking at the second, followed by West Palm Beach $(5,224)$, Salt Lake $(3,792)$, Allentown-Bethlehem-Easton $(3,750)$, Grand Rapids $(3,750)$, Dallas $(3,249)$, and Boston $(2,010)$. Except Boston and Dallas, many large computer and electronic manufacturing regions are losing ground because of industry consolidation and intensified competition from Asian countries in the recent year. San Jose lost almost one-fourth of employment, or nearly forty thousand computer and electronic manufacturing workers, the largest loser in three years. Philadelphia and Sacramento lost about twenty thousand computer and electronic manufacturing workers. Cedar Rapids, Detroit, Albuquerque, Nassau, and Phoenix also experienced substantial job losses in this sector (table 12). The spatial change also indicates that computer and electronic manufacturing industry is moving to middle or small-sized metropolitan areas to reduce production costs.

\section{Aerospace Product and Parts Manufacturing (NAICS 3364)}

Aerospace Product and Parts Manufacturing is one of the oldest high tech sectors with a high ratio of research and development expenditures to sales and great entry barriers. It is also a large recipient of federal defense expenditures. In 1998, this industry received $\$ 30$ billion from military contracts (Napier 1998). The U.S. aircraft industry represents more than 60 percent of the world aircraft market. It sold $\$ 47$ billion worth of 
aircraft and parts to civilian air carriers in 1998 (Napier 1999). The domestic and Asian economic downturn has slowed the civil aerospace sales, leading to substantial employment loss in the recent years. Between 1998 and 2001, aerospace product and parts manufacturing lost over thirteen percent employment. It is also the most concentrated industry among ten high tech sectors, with over sixty percent of employment clustering in ten metropolitan areas.

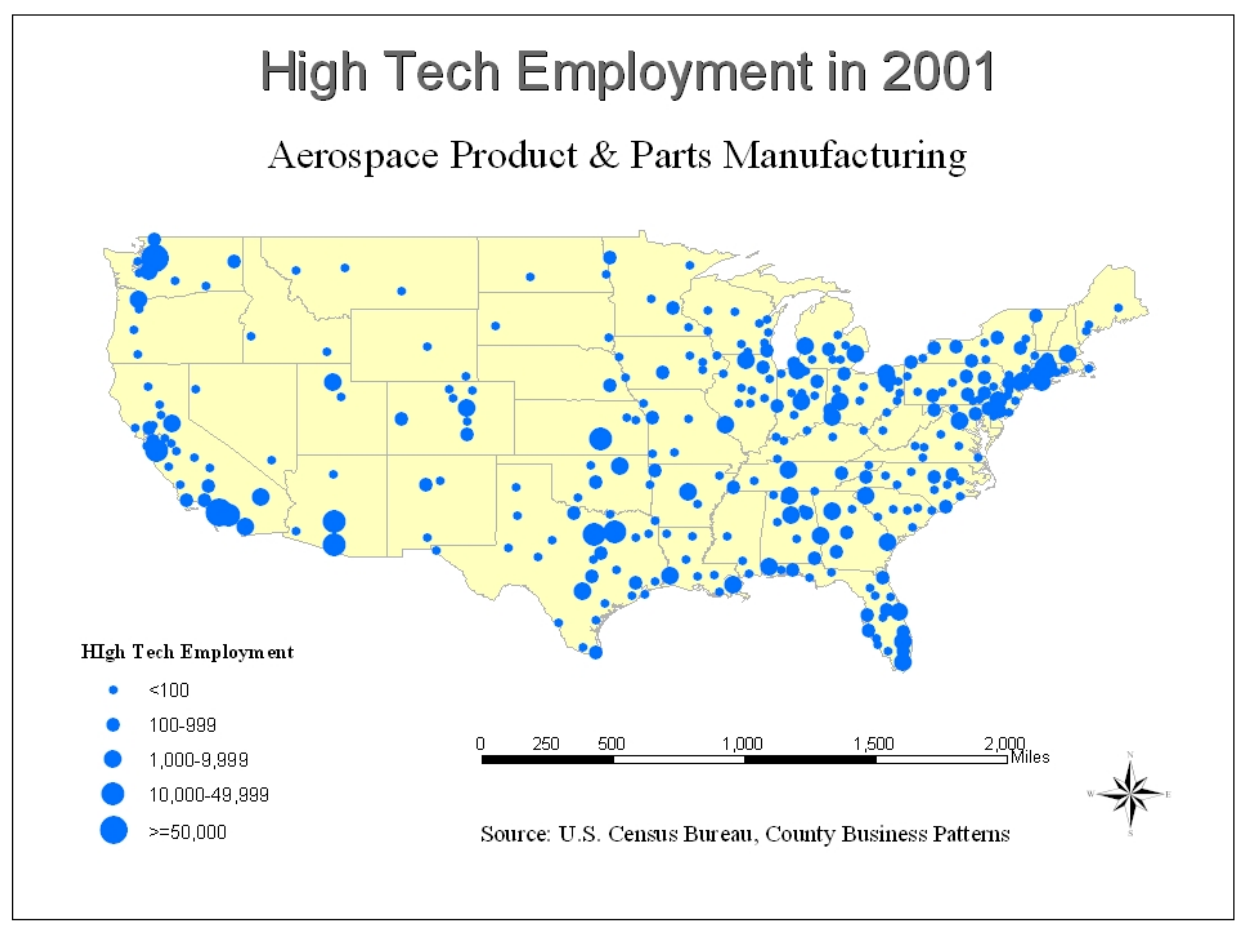

Figure 5 Spatial Allocations of Aerospace Product and Parts Manufacturing in 2001 
Table 13

Aerospace Product and Parts Manufacturing (NAICS 3364)

\begin{tabular}{|c|c|c|c|c|c|}
\hline \multicolumn{2}{|c|}{ Employment } & \multicolumn{3}{|c|}{ Jobs Gains } & \multirow{2}{*}{$\begin{array}{r}\text { Jobs Loss } \\
1998-2001\end{array}$} \\
\hline Metro & 2001 & Metro & $1998-2001$ & Metro & \\
\hline Seattle & 75,000 & Tucson & 10,000 & St. Louis & $-32,015$ \\
\hline Los Angeles & 51,770 & Nassau, NY & 937 & Los Angeles & $-21,415$ \\
\hline Wichita, KS & 37,500 & Ventura, CA & 591 & Atlanta & $-10,000$ \\
\hline San Jose & 17,500 & Utica--Rome, NY & 375 & New Haven & $-10,000$ \\
\hline Fort Worth, & \multicolumn{3}{|c|}{ Fayetteville-Springdale } & & \\
\hline $\mathrm{TX}$ & 17,500 & --Rogers, AR & 375 & West Palm Beach & $-5,653$ \\
\hline Phoenix & 17,500 & Williamsport, PA & 375 & Orange County & $-5,221$ \\
\hline Hartford, CT & 17,500 & Rockford, IL & 297 & Dallas & $-4,748$ \\
\hline Tucson, AZ & 17,500 & Fort Lauderdale, FL & 288 & Salt Lake City & $-2,000$ \\
\hline Orange County & 12,279 & Houston & 200 & New Orleans & $-2,000$ \\
\hline \multirow[t]{4}{*}{ Dallas } & 10,800 & Rochester, NY & 200 & \multirow[t]{4}{*}{ Waco, TX } & \multirow[t]{4}{*}{$-1,575$} \\
\hline & & Toledo, $\mathrm{OH}$ & 200 & & \\
\hline & & Asheville, NC & 200 & & \\
\hline & & Bellingham, WA & 200 & & \\
\hline
\end{tabular}

Source: Data Calculate from County Business Patterns 2001, U.S. Census Bureau

The Aerospace Product and Parts industry involves considerable interaction with the researchers and designers of the technological product to satisfy detailed technical specifications. This industry is characterized by a high level of concentration and dominated by a handful of firms. The Aerospace Product and Parts industry concentrates in Seattle, Los Angeles, Wichita, San Jose, Fort Worth, Phoenix, Hartford, Tucson, Orange County and Dallas. The largest metropolitan area, Seattle, contributes to about one-sixth of total aerospace manufacturing employment. The Boeing Co. is the largest aircraft manufacturer in the world. The merger of Boeing and McDonnell Douglas will further reinforce its global dominance. 
Table 13 also indicates that the aerospace products and parts manufacturing industry experienced dramatic decline on employment between 1998 and 2001. Only Tucson observed substantial employment growth with over 10,000 new jobs. Many large aerospace products manufacturing regions observed substantial job losses. St. Louis lost over thirty-two thousand, or more than eighty-five percent of aerospace manufacturing employment from 1998 to 2001. Los Angeles, the second largest aerospace manufacturing regions, lost more than twenty thousand, or almost thirty percent of its aerospace workers during the same period.

\section{Medical Equipment and Supplies Manufacturing (NAICS 3391)}

The Medical Equipment and Supplies Manufacturing industry is a mature industry with almost 300,000 employees in 1998. The decline on establishments and increase on employment indicates that it is currently experiencing a round of consolidation between 1998 and 2001. 


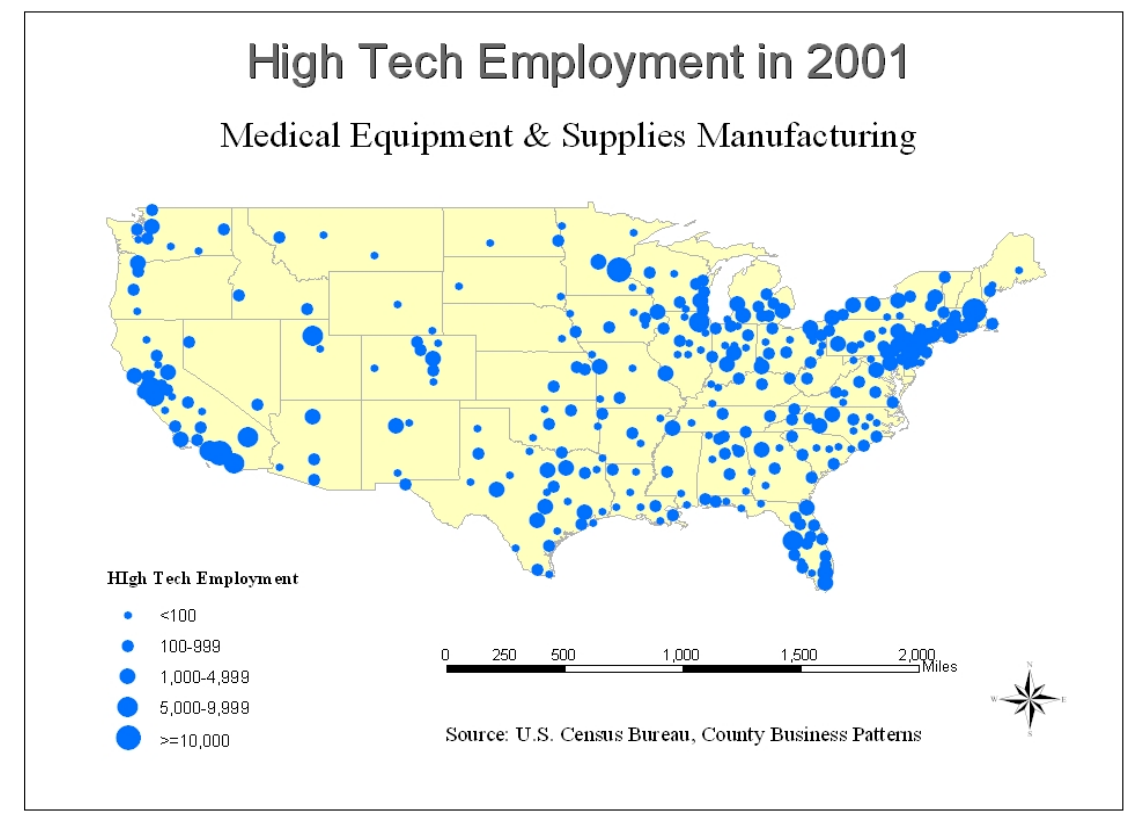

Figure 6 Spatial Allocations of Medical Equipment and Supplies Manufacturing in 2001

The Medical equipment and supplies manufacturing industry shows a similar spatial pattern with that of the entire high tech sector. The industry's employment concentrates in the major metropolitan areas of California, the Northeastern Corridor (WashingtonBoston), Florida, Texas and the Midwest. Boston leads the industry employment with 12,740 workers, followed by Minneapolis and Orange County, 12,614 and 10,700 respectively. Los Angeles, San Jose, Salt Lake City, Chicago, Tampa, Philadelphia, and San Diego also have a high concentration of medical equipment manufacturing employment. In terms of employment change, Oakland, Glens Falls, Riverside, Salt Lake City, Portland, Dallas, and Providence gained, while traditional medical equipment manufacturing regions such as Boston, New York, New Haven, and Fresno lost their 
shares. Boston lost over one-quarter of its employment from 1998 to 2001. New York and New Haven also lost over a thousand medical equipment manufacturing jobs.

\section{Table 14}

Medical Equipment and Supplies Manufacturing (NAICS 3391)

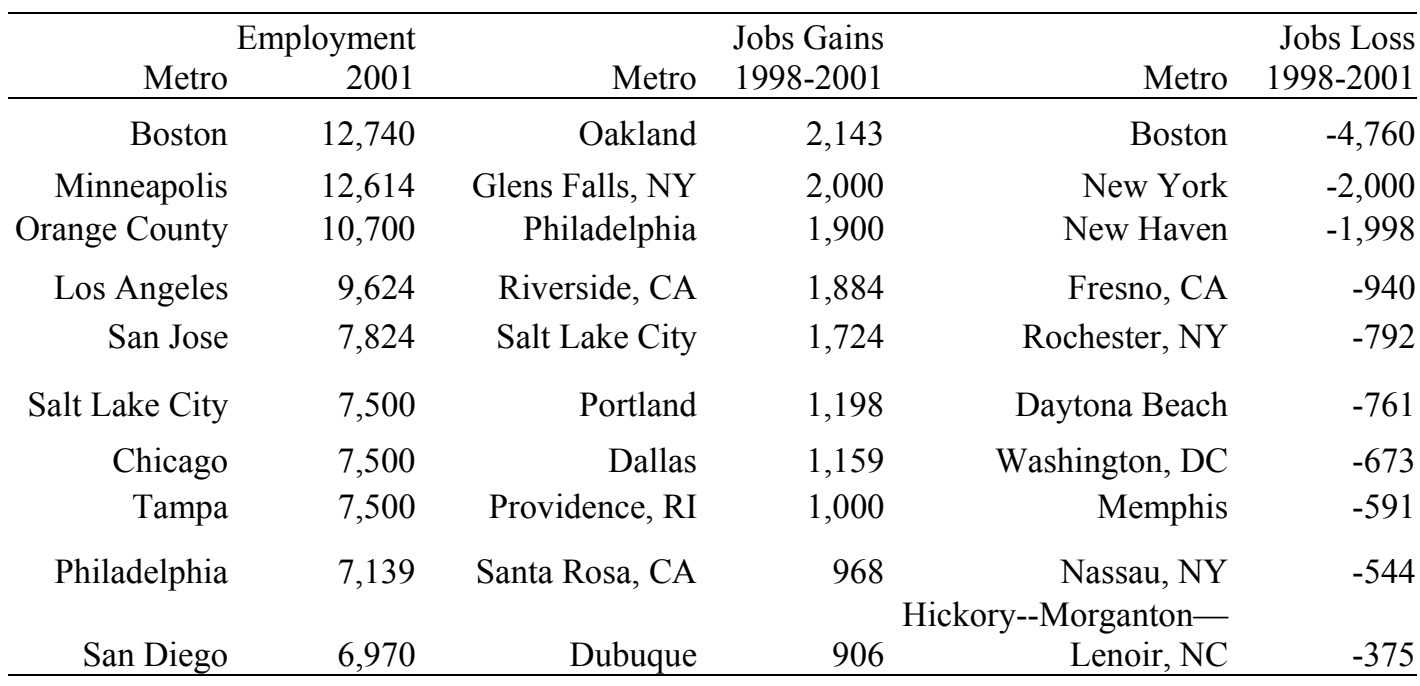

Source: Data Calculate from County Business Patterns, 2000, U.S. Census Bureau

\section{Software Publishers (NAICS 5112)}

The Software Publishers industry employed over 350 thousand individuals in March 2001, almost a one-quarter increase over that in 1998. Software publishers concentrated in the Northeastern Corridor (Washington-Boston), California, and major metropolitan areas of Texas, Florida, the Midwest and Seattle. The top ten software publishers regions are traditional high tech centers including Seattle, San Jose, Boston, San Francisco, Chicago, Atlanta, Dallas, Washington, D.C., Los Angeles and Oakland. These regions 
account for over one-half of industry employment and over one-third of national establishments. In other words, software publishers industry is a highly concentrated high tech sector.

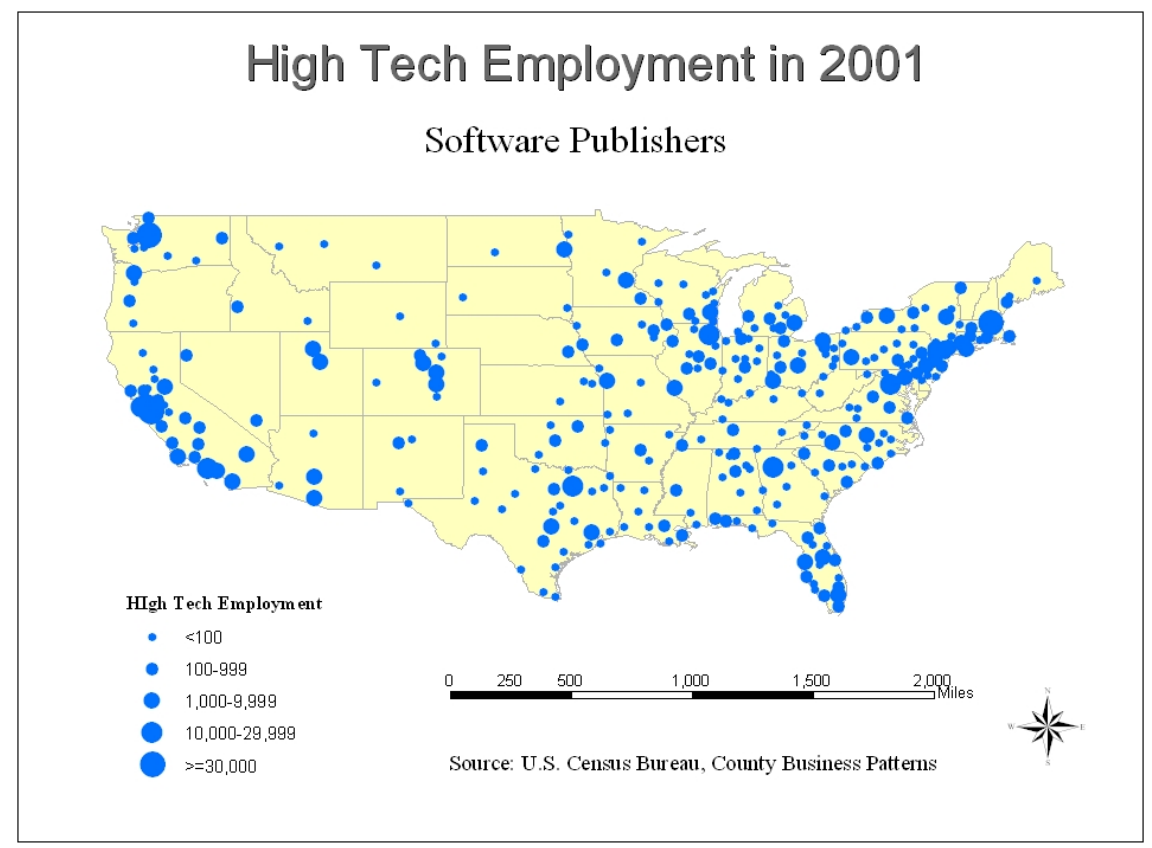

Figure 7: Spatial Allocations of Software Publishers in 2001

Table 15 suggests that the traditional Northeastern and Midwest MSAs are losing their shares, while western and southern metropolitan areas gain. The majority of employment growth occurs in traditional software development regions in the south and west. Seattle added twenty thousand new software workers, and Atlanta gained ten thousand industry employees between 1998 and 2001. At the same time, Washington D.C. lost almost six thousand software jobs, followed by Willmington, Ann Arbor and Indianapolis. Boston also observed job loss on software publishing during the same 
period. This indicates that the software publishers industry moved from the east to the west and south regions. The similar ranks between total employment and job growth also shows that this industry experiences monopolistic competition and continuing agglomeration.

Table 15

Software Publishers (NAICS 5112)

\begin{tabular}{rrrrrr}
\hline \multicolumn{2}{c}{ Employment } & & Jobs Gains & & Jobs Loss \\
Metro & 2001 & Metro & $1998-2001$ & Metro & $1998-2001$ \\
\hline Seattle & 37,500 & Seattle & 20,000 & Washington, D.C. & $-5,935$ \\
San Jose & 32,322 & Atlanta & 10,000 & Wilmington, DE--MD & $-1,575$ \\
Boston & 30,401 & San Jose & 6,640 & Ann Arbor & $-1,000$ \\
San Francisco & 24,591 San Francisco & 6,111 & Indianapolis & $-1,000$ \\
Chicago & 17,500 & Dallas & 4,725 & Provo--Orem, UT & -848 \\
Atlanta & 17,500 & Denver & 4,235 & Huntsville & -820 \\
Dallas & 12,022 & Los Angeles & 3,370 & Tampa & -802 \\
Washington, & \multicolumn{3}{c}{} & Boston & -598 \\
DC & 11,565 & Portland & 2,217 & Cedar Rapids, IA & -549 \\
Los Angeles & 10,641 & Raleigh & 2,000 & Fresno, CA & -539 \\
Oakland & 8,306 & Columbus & 2,000 & & \\
\hline
\end{tabular}

Source: Data Calculate from County Business Patterns, 2000, U.S. Census Bureau

Telecommunications (NAICS 5133)

The Telecommunications industry provides services to 94 million households and 25 million businesses nationwide (DeVol 1999). This industry has been facing fierce competition since the 1990s because of continued deregulation and overlapping markets. The industry employs 1.3 million people in 2001 , an increase of over 20 percent since 1998. The telecommunications establishments also increased almost by 30 percent in the 
same time frame.

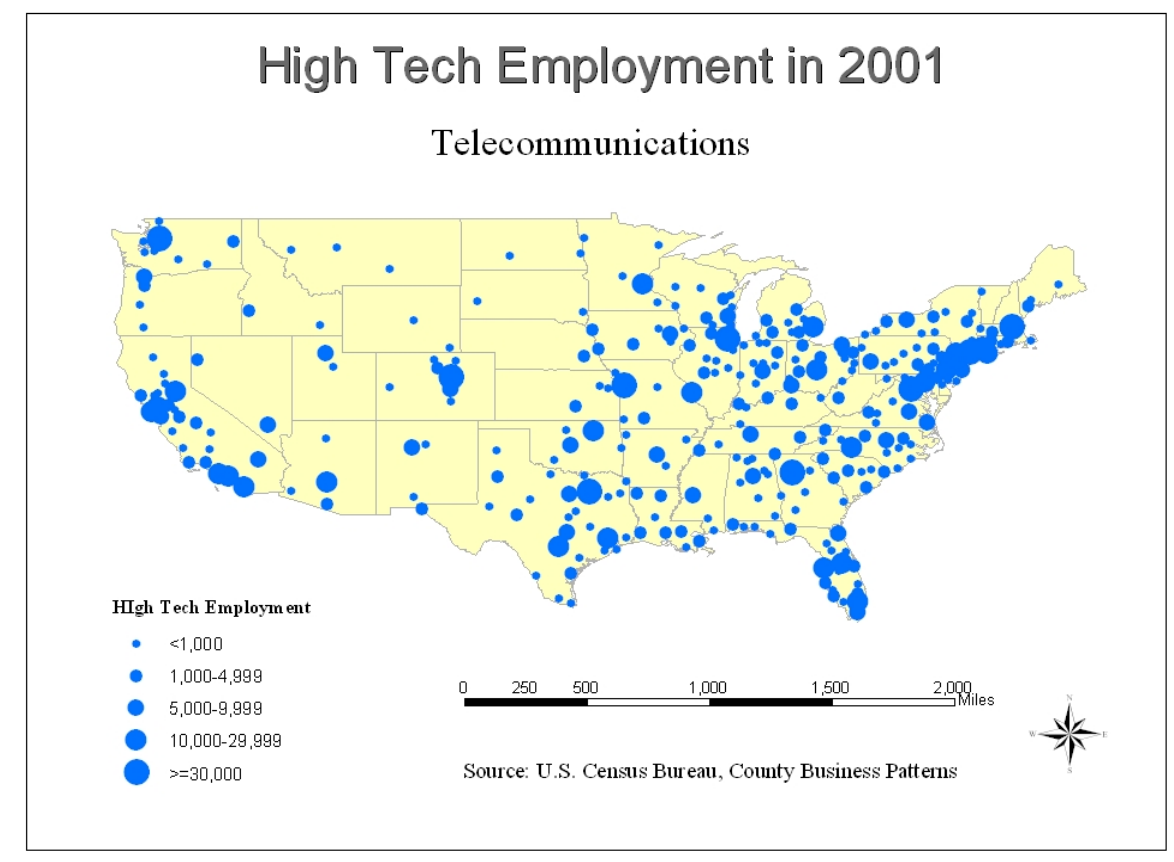

Figure 8: Spatial Allocations of Telecommunications in 2001

The Telecommunications industry concentrates in major metropolitan areas of California, the Northeastern Corridor (Washington-Boston), Texas, and regional high tech centers such as Seattle, Denver, and Kansas City. The largest telecommunications region is Atlanta, which has almost sixty thousand workers. Washington, D.C., Dallas, Chicago, Seattle, Denver, New York, Boston, Kansas City, and Los Angeles are also large telecommunication centers with over twenty-five thousand employees in each MSA. These metropolitan areas have significant levels of local infrastructure and are traditional centers for telecommunication access and development. For instance, Denver is home to some of the largest cable and telecommunication companies in the United States, 
including Qwest Communications and AT\&T Broadband.

Table 16

Telecommunications (NAICS 5133)

\begin{tabular}{|c|c|c|c|c|c|}
\hline \multicolumn{2}{|c|}{ Employment } & \multicolumn{2}{|r|}{ Jobs Gains } & \multicolumn{2}{|r|}{ Jobs Loss } \\
\hline Metro & 2001 & Metro & $1998-2001$ & Metro & 1998-2001 \\
\hline Atlanta & 59,775 & Atlanta & 22,275 & Oakland & $-5,053$ \\
\hline Washington, & & & & & \\
\hline DC & 55,353 & Seattle & 20,000 & Los Angeles & $-2,270$ \\
\hline Dallas & 43,193 & Washington, DC & 15,300 & Fresno, CA & $-2,000$ \\
\hline Chicago & 42,414 & Kansas City & 12,109 & Grand Rapids, MI & $-2,000$ \\
\hline Seattle & 37,500 & Columbus & 10,000 & Colorado Springs & $-1,652$ \\
\hline Denver & 37,500 & New Haven & 10,000 & San Jose & $-1,584$ \\
\hline New York & 37,500 & Nassau, NY & 10,000 & Portland & $-1,391$ \\
\hline Boston & 35,376 & Tulsa, OK & 10,000 & $\begin{array}{c}\text { Charleston } \\
\text { Longview }\end{array}$ & $-1,088$ \\
\hline Kansas City & 33,915 & Boston & 8,616 & --Marshall, TX & $-1,000$ \\
\hline Los Angeles & 26,152 & Dallas & 6,995 & San Francisco & -920 \\
\hline
\end{tabular}

Source: Data Calculate from County Business Patterns, 2000, U.S. Census Bureau

The most significant employment growth in this industry occurred in Atlanta and Seattle with over twenty thousand new telecommunications employees in each MSA.

Table 16 also illustrates that large metropolitan areas such as New York, Los Angeles, Chicago, and San Francisco experienced telecommunications employment decline under significant competitions created by deregulation. On the other hand, some medium sized metropolitan areas such as Seattle, Kansas City, Columbus, New Haven, Nassau, and Tulsa are now benefiting from competition and continued deregulation with substantial job gains from 1998 to 2001 . Telecommunications is a relatively mature industry with employment spreading to medium-sized MSAs to reduce costs and access markets. 


\section{$\underline{\text { Information and Data Processing Services (NAICS 514) }}$}

Information and Data Processing services are the fastest growing industry among the ten high tech sectors. Between 1998 and 2001, this industry gained almost fifty percent of employment and over one-third of establishments nationally, showing the increasing market demand for this service sector. The Information and data processing industry concentrates in Northeastern Corridor and major metropolitan regions in California, Florida, Texas, and the Midwest states. New York and Boston are the largest metropolitan areas on information and data services employment, followed by Washington D.C., Los Angeles, Dallas, Atlanta, Chicago, Phoenix, Detroit and San Jose.

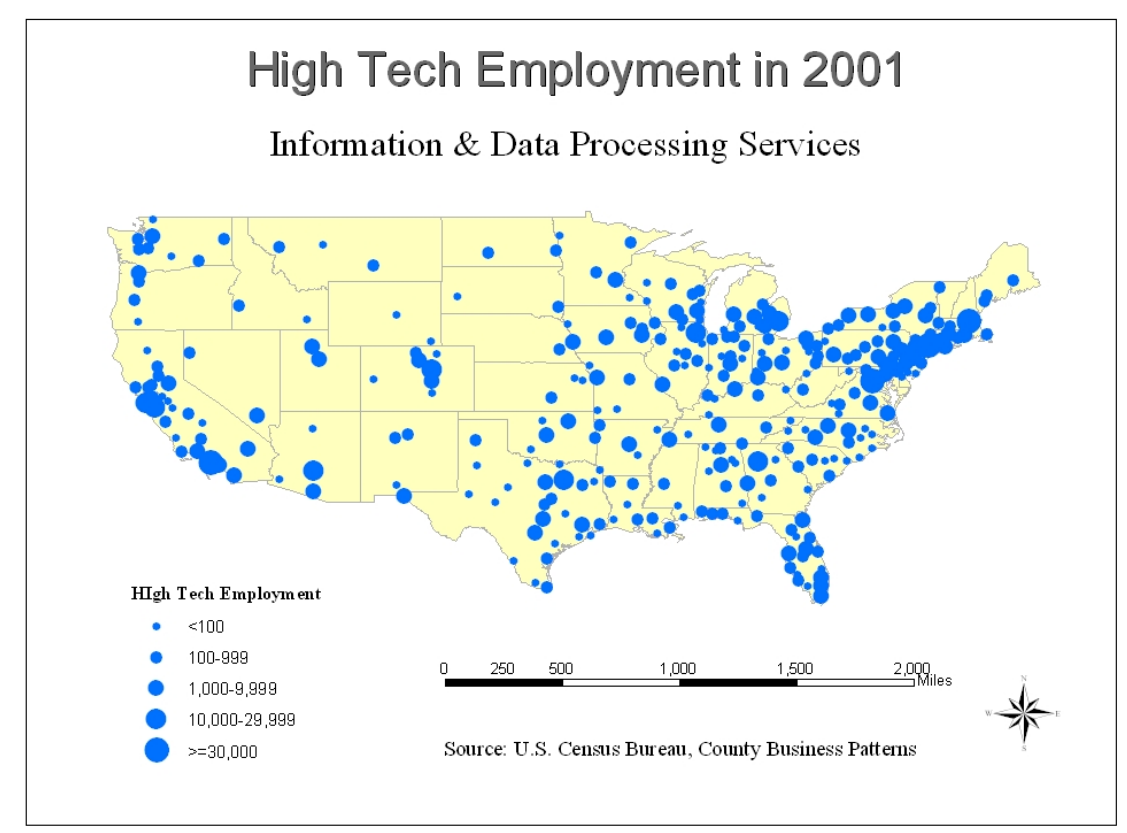

Figure 9: Spatial Allocations of Information and Data Processing Services in 2001 
Table 17

Information and Data Processing Services (NAICS 514)

\begin{tabular}{rrrrrr}
\hline \multicolumn{2}{r}{ Employment } & & Jobs Gains & Jobs Loss \\
Metro & 2001 & Metro & $1998-2001$ & Metro & $1998-2001$ \\
\hline New York & 37,500 & New York & 20,000 & Omaha, NE--IA & $-10,000$ \\
Boston & 37,500 & Boston & 20,000 & Columbia, SC & $-3,197$ \\
Washington, & & & & \\
DC & 34,677 & Los Angeles & 17,937 & Albany, NY & $-2,000$ \\
Los Angeles & 33,548 & Phoenix & 13,750 & New London, CT & -977 \\
Dallas & 22,554 & San Jose & 12,438 & Louisville & -519 \\
Atlanta & 17,500 & Atlanta & 10,000 & Huntsville & -375 \\
Chicago & 17,500 & Chicago & 10,000 & Hattiesburg, MS & -375 \\
Phoenix & 17,500 & San Francisco & 9,710 & Cincinnati & -323 \\
Detroit & 17,500 & Oakland & 7,431 & Madison & -237 \\
San Jose & 17,358 Washington, DC & 6,564 & Knoxville & -200 \\
\hline \multicolumn{5}{c}{}
\end{tabular}

Source: Data Calculate from County Business Patterns 2001, U.S. Census Bureau

The majority of employment growth in information and data processing industry occurred in several large high tech centers including New York, Boston, Los Angeles, Phoenix, San Jose, Atlanta, and Chicago. Omaha leads the way on job declines. It lost about 10,000 workers in this sector between 1998 and 2001, followed by Columbia, SC and Albany, NY with an over-2000 jobs decline in each MSA during the same time frame. 


\section{Architectural, Engineering \& Related Services (NAICS 5413)}

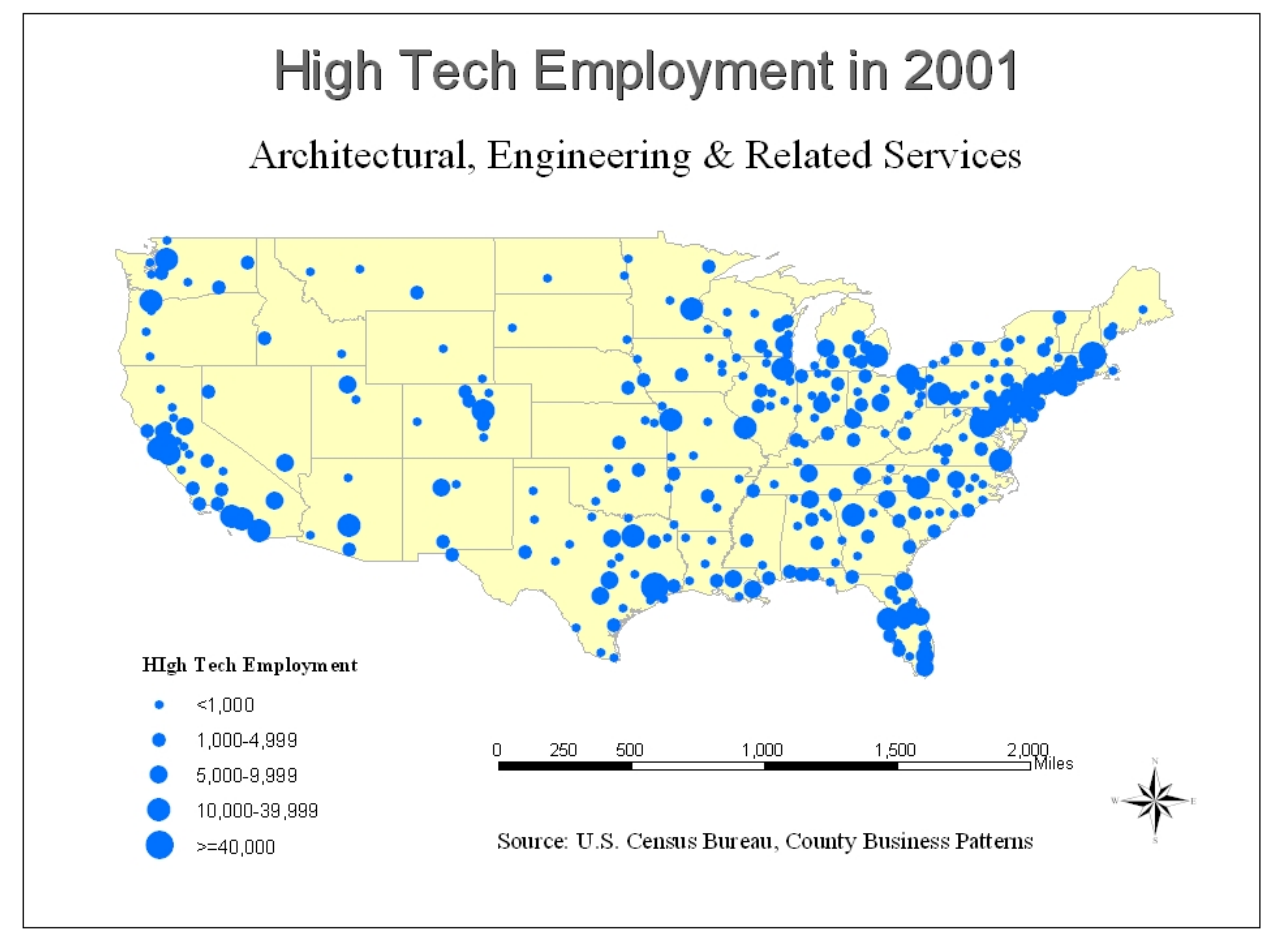

Figure 10: Spatial Allocations of Architectural, Engineering \& Related Services in 2001

This small high tech sector is relatively spread out compared to other high tech

industries. The top ten MSAs represent approximately thirty percent of architectural, engineering and related service employment nationally. In addition, the top Architectural, Engineering and Related services regions are large metropolitan areas around the United States. Washington, D.C. is the largest metropolitan area with over 60,000 architectural and engineering professionals in 2001. Boston and Houston ranks at the second and third, with more than 45,000 professionals in this sector in 2001, followed by Chicago, Atlanta, and Philadelphia. Table 18 also indicates that these top ten MSAs are traditional and large 
high tech centers. Atlanta and San Jose were large gainers with over 10,000 new jobs on architectural, engineering and related services from 1998 to 2001. Cleveland, Boston, New York, Kansas City and San Diego also experienced substantial employment growth during the same period. On the other hand, Houston lost almost thirty thousand employments, and was the largest loser from 1998 to 2001. Washington D.C. was the second loser with over fourteen thousand employment decline on the same time frame. St. Louis, Albuquerque, Jacksonville, and Richland also experienced employment declines in three years.

\section{Table 18}

Architectural, Engineering \& Related Services (NAICS 5413)

\begin{tabular}{rrrrrr}
\hline \multicolumn{2}{r}{ Employment } & & Jobs Gains & & Jobs Loss \\
Metro & 2001 & Metro & $1998-2001$ & Metro & $1998-2001$ \\
\hline Washington, DC & 60,365 & Atlanta & 13,413 & Houston & $-29,741$ \\
Boston & 45,365 & San Jose & 10,060 & Washington, DC & $-14,635$ \\
Houston & 45,259 & Cleveland & 8,285 & St. Louis & $-5,534$ \\
Chicago & 39,524 & Boston & 6,520 & Albuquerque & $-2,459$ \\
Atlanta & 37,500 & New York & 5,035 & Jacksonville & $-2,235$ \\
Philadelphia & 37,500 & Kansas City & 4,528 & Richland, WA & $-2,000$ \\
Los Angeles & 35,898 & San Diego & 4,383 & Greenville, SC & $-1,478$ \\
New York & 31,457 Los Angeles & 3,751 & Wichita, KS & $-1,374$ \\
Detroit & 31,450 & Denver & 3,479 & Baltimore & $-1,200$ \\
San Jose & 27,897 & Phoenix & 3,232 & Pittsburgh & $-1,188$ \\
\hline
\end{tabular}

Source: Data Calculate from County Business Patterns, 2000, U.S. Census Bureau

\section{Computer System Design \& Related Services (NAICS 5415)}

The Computer System Design \& Related services are among the fastest growing 
industries in the U.S. economy. From 1998 to 2001, computer system design \& related services gained over forty-three percent of employment and over one-fifty of establishments nationally. Since the output produced by this industry is knowledge, it requires a relatively small investment on capital equipment. The development of this industry depends on market demands and the availability of a knowledgeable workforce, which are abundant in large metropolitan areas.

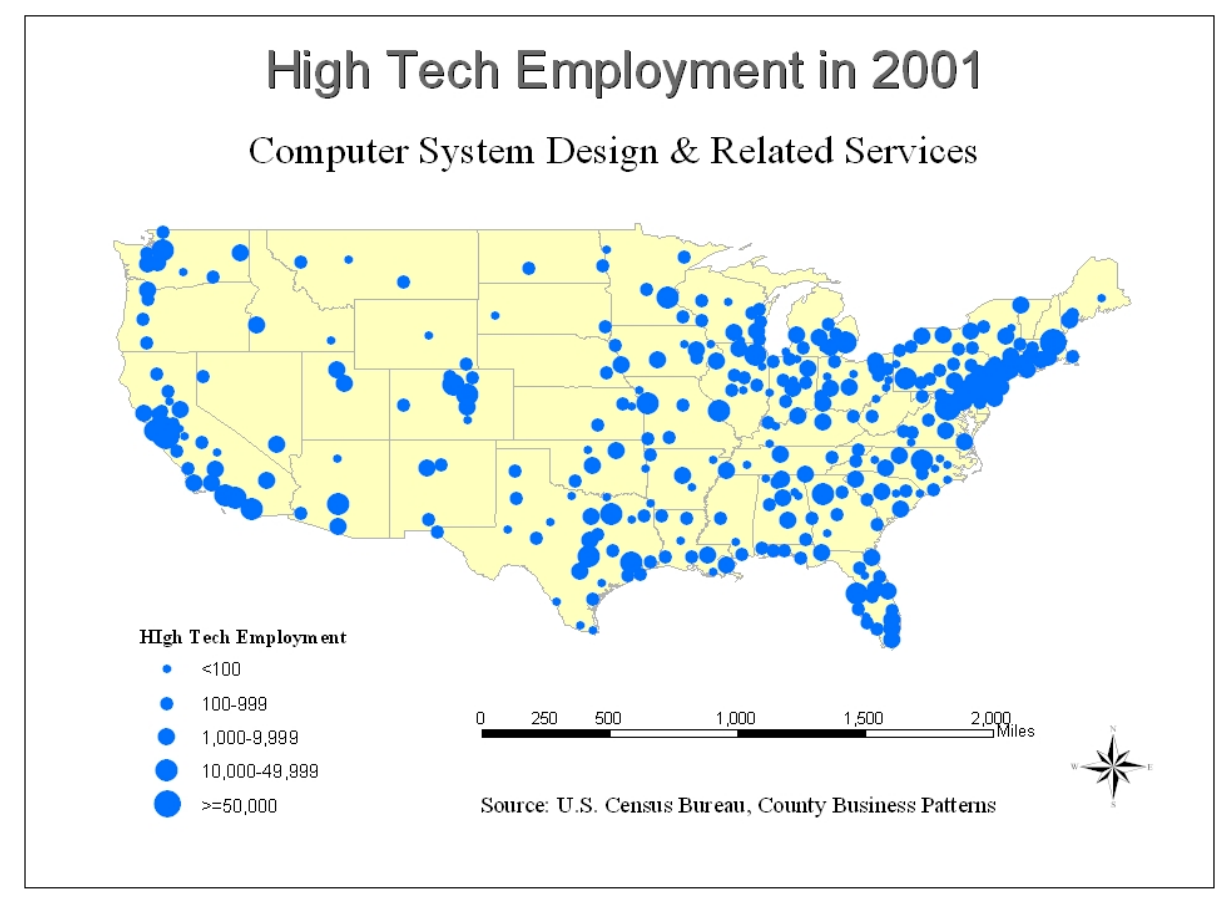

Figure 11: Spatial Allocations of Computer System Design \& Related Services in 2001

The top computer system design and service regions are traditional high tech poles. Washington D.C., the largest high tech service region, ranks again on the top with over 128,000 workers in this industry. Boston and San Jose follow with over sixty thousand 
computer system design and related service professionals in each MSA. The other top MSAs in this sector include Chicago, Atlanta, Philadelphia, New York, Minneapolis, Middlesex, and San Francisco. The largest computer system design and related service metropolitan areas in this sector are also among the top ten in terms of employment growth except Chicago. Washington D.C. gained over fifty thousand professionals from 1998 to 2001, the largest gainer in this sector, followed by San Jose, Boston, San Francisco, Minneapolis, Middlesex, and New York. St. Louis and Chicago each lost over two thousand workers at the same time frame. Compared the number of jobs gains with employment declines, we could tell that computer system design and related services is currently a fast growing industry with substantial employment growth in large high tech metropolitan areas.

\section{Table 19}

Computer System Design \& Related Services (NAICS 5415)

\begin{tabular}{|c|c|c|c|c|c|}
\hline \multirow{2}{*}{$\begin{array}{r}\text { Metro } \\
\text { Washington, }\end{array}$} & \multicolumn{2}{|c|}{ Employment } & \multicolumn{2}{|l|}{ Jobs Gains } & \multirow{2}{*}{$\begin{array}{l}\text { Jobs Loss } \\
998-2001\end{array}$} \\
\hline & 2001 & Metro & $1998-2001$ & Metro & \\
\hline $\begin{array}{r}\text { Washington, } \\
\text { DC }\end{array}$ & 128,677 & Washington, DC & 53,677 & St. Louis & $-2,468$ \\
\hline Boston & 66,328 & San Jose & 36,095 & Chicago & $-2,105$ \\
\hline San Jose & 61,388 & Boston & 29,419 & Bryan--College Station, TX & $-1,219$ \\
\hline Chicago & 37,500 & San Francisco & 17,929 & Columbia, SC & $-1,185$ \\
\hline Atlanta & 37,500 & Minneapolis & 17,095 & Little Rock, AR & -687 \\
\hline Philadelphia & 37,500 & Middlesex, NJ & 13,930 & Cleveland & -523 \\
\hline New York & 37,500 & New York & 11,016 & South Bend, IN & -390 \\
\hline Minneapolis & 37,500 & Oakland & 10,910 & Memphis & -369 \\
\hline Middlesex, NJ & 36,528 & Phoenix & 10,000 & Provo--Orem, UT & -348 \\
\hline San Francisco & 36,202 & Kansas City & 10,000 & Rochester, MN & -290 \\
\hline
\end{tabular}

Source: Data Calculate from County Business Patterns, 2000, U.S. Census Bureau 


\section{Scientific R\&D Services (NAICS 5417)}

Scientific Research and Development Services are among the smallest high tech sectors with fewer than four hundred thousand workers nationally in 2001. However, it experiences a very fast growth rate and high industrial concentration. From 1998 to 2001, scientific R\&D services gained almost one-quarter of employment and nearly one-sixth of establishments around the United States. The top ten largest scientific R\&D MSAs represent more than one half of industrial employment and over one-third of establishments nationally in 2001.

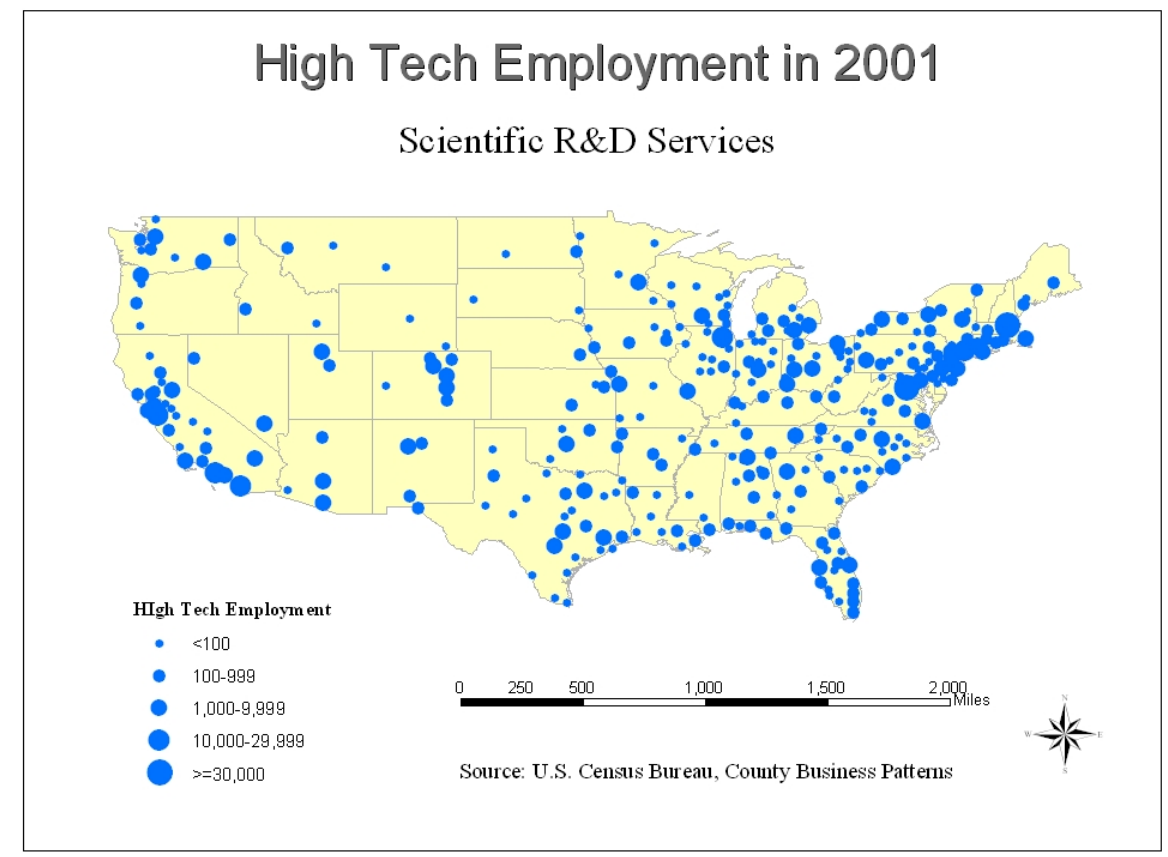

Figure 12: Spatial Allocations of Scientific R\&D Services in 2001

The largest high-tech service region, Washington D.C., ranked at the top with over 
forty-four thousand industrial employment in 2001. Boston and San Diego ranked second and third respectively, with 37,500 and 24,141 workers in this sector. San Jose, Chicago, New York, Los Angeles, San Francisco, and Philadelphia are also large scientific R\&D regions. These top MSAs experienced large employment growth from 1998 to 2001 . Boston gained over sixteen thousand workers and Washington added more than nine thousand professionals, followed by San Jose, San Diego, Houston, Newark, and San Francisco. Albuquerque is the only metropolitan area that experienced substantial job losses in this industry, with over fifteen thousand jobs lost from 1998 to 2001. Other MSAs had fewer than 700 employment declines in this sector.

Table 20

Scientific R\&D Services (NAICS 5417)

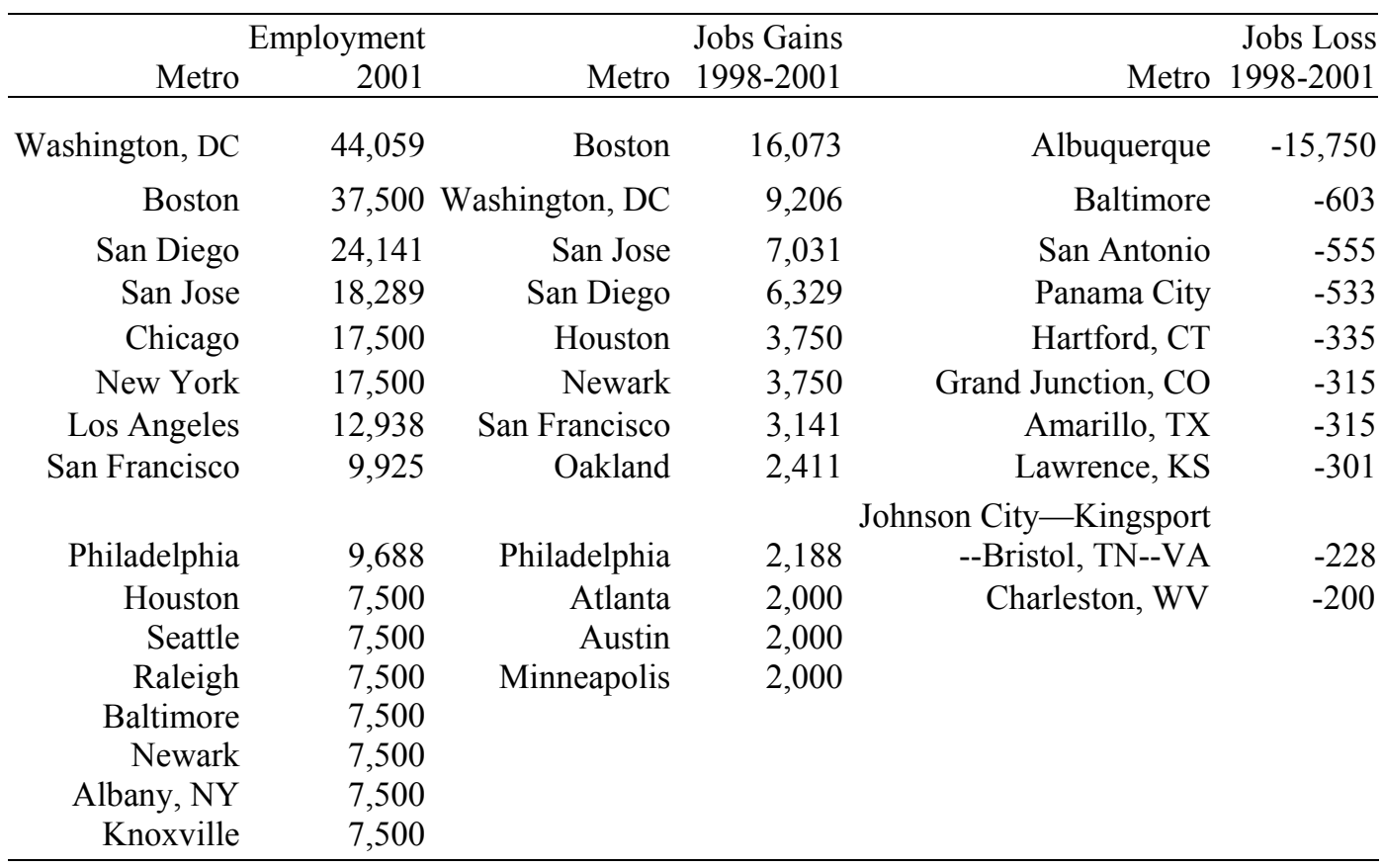

Source: Data Calculate from County Business Patterns 2001, U.S. Census Bureau 
High tech industries showed both similarities and differences in terms of employment growth and spatial redistribution between 1998 and 2001. High-tech manufacturing sectors displayed concentrated spatial patterns, with slow or negative employment growth between 1998 and 2001. Pharmaceutical and Medicine Manufacturing industrial employment showed a steady growth pattern and concentrations in the Northeastern Corridor, California and the Midwest. Aerospace Product and Parts Manufacturing experienced substantial employment loss and continued to concentrate in a few MSAs such as Seattle, Los Angeles and Wichita, KS. Computer \& Electronic Product Manufacturing and Medical Equipment \& Supplies Manufacturing employment shifted from the traditional, large high tech centers to small or medium-sized MSAs to reduce production costs between 1998 and 2001.

High-tech service sectors experienced substantial growth, with an average of 25 percent employment growth from 1998 to 2001. Software Publishers continued to concentrate in the Northeastern Corridor, California, and other traditional high tech centers. In terms of employment change, traditional Northeastern and Midwest MSAs were losing their shares, while western and southern MSAs such as Seattle, and Atlanta gained in this sector. Telecommunications is a relatively mature service industry with employment spreading to the medium-sized MSAs and regional economic center. Information \& Data Processing services and Computer System Design \& Related 
Services are fast growing service sectors concentrating in traditional high tech poles and the large metropolitan areas because their development depends on market demands and the availability of a knowledge-based workforce and a relatively low investment on capital equipment. Architectural, Engineering and Related Services employment is relatively spread out across the MSAs, while Scientific R\&D services are highly concentrated in order to access the top ranked research facilities. 


\section{CHAPTER 6}

\section{FINDINGS AND ANALYSIS}

High tech industries have displayed geographic imbalances since their inception. The spatial analyses in the previous chapter show that the majority of high tech industries are concentrated in California, the Northeastern Corridor (Boston - Washington D.C.), and the major metropolitan regions of Florida, and Texas and regional economic centers such as Seattle, Atlanta, Phoenix, Chicago, and Minneapolis. Why did Atlanta, Phoenix, San Francisco, Raleigh, and Kansas City, among others, gain high tech employment, while St. Louis, Detroit, and Houston experienced substantial high tech job losses from 1998 to 2001? Which location factors influenced high tech employment change across the MSAs?

In this chapter, I discuss how the study utilizes multivariate regression analysis to explore the impacts of location factors on high tech industrial employment. The analytical results will further explore human capital theory, agglomeration economies theory, classical location theory, and creative cities theory and their effectiveness in explaining high tech spatial concentration. The units of statistical analysis are 316 Metropolitan Statistical Areas (MSAs), Primary Metropolitan Statistical Areas (PMSAs) and New 
England County Metropolitan Areas (NECMAs). The dependent variables are total high tech employment in 2001 (log transformation) and the change of total employment for ten selected high tech sectors in each metropolitan area from 1998 to 2001. The independent variables include sixteen variables representing each metropolitan area's education, human capital, quality of life conditions, agglomeration, a diversified social environment, transportation and other production cost factors. The majority of the independent variables are measured using data from 1998. Some data, such as age, are relatively static and do not observe big changes in a few years. I use data from the U.S. Census Bureau 2000 (see Table 3).

The study first checks data for their completeness. Except for two quality of life variables, climate and crime rate, the other fourteen variables have complete data without any missing values. The climate variable has 192 values, and the crime rate variable has 239 values. First, these two variables are checked for linearity using bivariate scatter plots of the relationships with high tech employment. Based on the results from the scatter plots, climate and crime rate variables do not appear to have any curvilinear relationship with the dependent variables. Then I looked at their relationships with high tech employment using the following linear regressions: 
High-Tech Employment $=\alpha+\beta$ Climate + error

$$
(\mathrm{n}=192)
$$

High-Tech Employment $=\alpha+\beta$ Crime + error

$$
(\mathrm{n}=239)
$$

\section{Table 21}

Summary of Climate and Crime Rate estimating high tech employment, (1998-2001)

\begin{tabular}{|r|r|r|r|r|r|}
\hline IV & DV & $\begin{array}{r}\text { Standard } \\
\text { Coefficients }\end{array}$ & t Statistics & P Value & R Square \\
\hline Climate & $\begin{array}{r}\text { High-Tech Employment in } \\
2001\end{array}$ & .005 & .075 & .941 & .000 \\
\cline { 2 - 6 } & $\begin{array}{r}\text { High-Tech Employment } \\
\text { Change, 1998-2001 }\end{array}$ & .008 & .115 & .909 & .000 \\
\hline $\begin{array}{r}\text { Crime } \\
\text { Rate }\end{array}$ & $\begin{array}{r}\text { High-Tech Employment in } \\
2001\end{array}$ & .000 & .226 & .821 & .000 \\
\cline { 2 - 6 } & $\begin{array}{r}\text { High-Tech Employment } \\
\text { Change, 1998-2001 }\end{array}$ & -.080 & 1.231 & .219 & .006 \\
\hline
\end{tabular}

The statistical results are shown in Table 21. The climate variable has an expected positive coefficient on high tech employment change, but is not significant with a $p$ value equal to 0.941 . The $\mathrm{R}$ square is zero, indicating that climate has a very limited contribution to explain high tech employment concentration. Similarly, crime rate shows an expected negative sign, but is insignificant, with an extremely low R square. In other words, these two quality of life variables are statistically insignificant in explaining both high tech employment concentration in 2001 and the employment change in these high tech industries from 1998 to 2001. Their low t-statistics and nearly zero R-squares appear to indicate that their contributions to high tech spatial concentration are almost negligible. 
Since this study could not find any significant relationships between climate and crime rate and high tech employment concentration, I exclude climate and crime rate variables from the forthcoming statistical analysis to maintain a total sample of $n=316$.

The data for each of the variables are also checked for multicollinearity. Through the SPSS multicollinearity test such as their correlations and collinearity diagnostic test, I found that some independent variables have collinear relationship. For instance, the presence of a top-ranked research institution, academic research and the percentage of science \& engineering graduates are highly correlated with each other. The presence of an international airport is highly correlated with total miles of highways in an MSA at a coefficient of 0.716 , since both of them represent a transportation network in a region. I tried various transformations for some independent variables, and the multi-collinearity problem still existed among some variables. Given the strong correlations among some independent variables and the collinearity results run from the SPSS collinearity diagnostic test, this study excludes the percentage of science and engineering graduates and the total highway mileages in an MSA in the forthcoming regression analysis. The following section discusses statistical findings by each theory. 


\section{Analysis of Human Capital Factors on High Tech Employment Change}

\section{Table 22}

Summary of Human Capital Variables estimating high tech employment, 1998-2001 ( $\mathrm{t}$ values are in parentheses)

\begin{tabular}{|r|r|r|}
\hline Variables & DV: High Tech 2001 & DV: High Tech Change \\
\hline AGE & 0.349 & 0.220 \\
& $(7.831)$ & $(4.311)$ \\
& $* * *$ & $* * *$ \\
\hline EDU & 0.221 & 0.034 \\
& $(4.675)$ & $(0.630)$ \\
& $* * *$ & \\
\hline ACADEMIC & 0.340 & 0.470 \\
RESEARCH & $(7.319)$ & $(8.860)$ \\
& $* * *$ & $* * *$ \\
\hline R Square & 0.521 & 0.375 \\
\hline Adjusted R Square & 0.516 & 0.369 \\
\hline
\end{tabular}

Notes:

DV: high tech change, means the change of total employment for ten selected high tech sectors in each MSA from 1998 to 2001

DV: high tech 2001, means the total employment for ten selected high tech sectors in each MSA in 2001 (log transformation)

* Significance level $\mathrm{p}<0.1$

$* *$ Significance level $\mathrm{p}<0.05$

$* * *$ Significance level $\mathrm{p}<0.01$

The first five variables AGE, EDU, UNIV, Academic Research and Science and Engineering Graduates are human capital variables. Since UNIV, Academic Research, and Science and Engineering Graduates are all university-related variables, they are highly correlated among each other. In this section, I include academic research and exclude UNIV and Science \& Engineering Graduate variables to reduce multicollinearity. An important result in Table 22 is the strongly positive coefficients of academic research in both models. In other words, academic research is strongly correlated to both high tech 
employment in 2001 and high tech employment change between 1998 and 2001, with coefficients positively significant at the 99.9 percent $(p<0.001)$ confidence level. It appears to indicate that academic research has a strongly positive impact on high tech employment concentration. This finding is consistent with a wide variety of studies that claim the crucial role of a top ranked research institution in promoting high tech growth and production concentration (Dorfman 1983, Malecki 1986, Nelson 1986, Lund 1986, Rees and Stafford 1986, Vaughan and Pollard 1986, Rees and Stafford 1986, Harding 1989, Jaffe 1989, Luger \& Goldstein 1991, Mansfield 1991, Bania, Calkins and Dalenberg 1992, Parker and Zilberman 1993, Sivitanidou and Sivitanides 1995, Anselin, Varga and Acs 1997, Rondinelli 1998, DeVol 1999, Cohen 2000, Fulton and Shigley 2001). It definitely supports Lucas's human capital theory that world famous research institutions are the driving force for high tech growth (Lucas 1988).

The percentage of people aged 25 to 44 is an important human capital indicator, meaning a relatively young and energetic labor force. As expected, it shows strongly significant and positive relationships with both high tech employment in 2001 and high tech employment growth between 1998 and 2001, further supporting the importance of human capital on high tech industrial concentration.

Education, the percentage of people with at least a bachelor degree, is a typical indicator for a knowledge-based labor force. Cohen claims that education is one of the 
top reasons for a firm to choose a location (Cohen 2000). Rauch states that each additional year of an SMSA's average education can be expected to raise total productivity by 2.8 percent (Rauch 1993). The Milken Institute lists education of the workforce as a top factor that determines where high tech is concentrated (DeVol 1999). When estimating high tech employment in 2001, the education variable is strongly significant (positive) at the 99.9 percent $(\mathrm{p}<0.001)$ confidence level. This is consistent with human capital theory and research findings from various studies mentioned above. However, the education variable does not display a significant relationship with high tech employment change from 1998 to 2001 (see Table 22). High tech employment growth in these three years seems to be more strongly related to the presence of top ranked research universities than to education attainment in an MSA. A possible reason for this result may be the short time range of the analysis.

In summary, the findings in this analysis suggest that high tech industries prefer metropolitan regions with the presence of top ranked research universities and a young and well-educated labor force. It definitely supports human capital theory that expenditure on education and academic research has a positive impact on high tech employment concentration.

Quality of life advocates suggest that regional amenities and environmental quality attract knowledge workers, and these skilled workers further attract more high tech firms 
into the region. Quality of life variables are highly ranked as important location factors for high tech businesses by some scholars (Blair and Premus 1987, Schmenner 1982, Gottlieb 1995, Granger and Blomquist 1999, Florida 2000, Salvesen and Renski 2002). In addition to crime rate and climate variables mentioned before, this study introduced two other quality of life variables, housing affordability and location near a sea coast or the Great Lakes. Housing affordability is the ratio of median housing value to median household income in a metropolitan area. It is an indicator of cost of living conditions in a region. The higher the ratio of median housing value to median household income, the less affordable housing is. Gottlieb argues that housing affordability has a great impact on the location of high-tech businesses (Gottlieb 1994). Cohen lists affordable housing as one of the most important quality of life factors that attract knowledge workers into a region (Cohen 2000). In this study, I expect a negative relationship between the housing affordability variable and high tech employment concentration. Coastal location is a geographic variable. Oceanfront regions usually have an enjoyable climate and outstanding recreational opportunities. This study hypothesizes a significantly positive correlation between a coastal location and high tech employment cluster. 
Table 23

Summary of Quality of Life factors estimating high tech employment, 1998-2001 (t values are in parentheses)

\begin{tabular}{|l|r|r|}
\hline Variables & DV: High Tech 2001 & DV: High Tech Change \\
\hline AGE & 0.348 & 0.215 \\
& $(7.885)$ & $(4.248)$ \\
& $* * *$ & $* * *$ \\
\hline EDU & 0.224 & -0.007 \\
& $(4.464)$ & $(-0.128)$ \\
& $* * *$ & \\
\hline ACADEMIC & 0.320 & 0.443 \\
RESEARCH & $(6.854)$ & $(8.281)$ \\
& $* * *$ & $* * *$ \\
\hline HOUSING & -0.003 & 0.108 \\
AFFORDABILITY & $(-0.058)$ & $(2.033)$ \\
& & $* *$ \\
\hline COAST & 0.120 & 0.063 \\
& $(2.977)$ & $(1.360)$ \\
& $* * *$ & 0.390 \\
\hline R Square & 0.535 & 0.015 \\
R Square Change & 0.014 & \\
\hline
\end{tabular}

Notes:

DV: high tech change, means the change of total employment for ten selected high tech sectors in each MSA from 1998 to 2001

DV: high tech 2001, means the total employment for ten selected high tech sectors in each MSA in 2001 (log transformation)

* Significance level $\mathrm{p}<0.1$

** Significance level $\mathrm{p}<0.05$

*** Significance level $\mathrm{p}<0.01$

The statistical results in Table 23 show that the housing affordability variable has an expected negative relationship with high tech employment in 2001, but is insignificant. Furthermore, it shows a positive correlation with high tech employment change from 1998 to 2001, opposite to our expectation. This may indicate that high tech firms select high cost of living regions in order to access other favorable resources such as a well- 
educated labor force. Other factors, such as the concentration of educated professionals, may outweigh the importance of low cost of living in influencing high tech firms' location decisions. Coastal location variable has expected positive sign, but is only significant in estimating high tech employment in 2001. The R square changes compared to human capital variables are small, 0.014 and 0.015 respectively. From these statistical findings, plus previous analyses on climate and crime rate variables, this study could not find a strong, significant and consistent relationship between quality of life factors and high tech employment from 1998 to 2001. There may be several reasons for insignificant correlations between quality of life variables and high tech employment clusters. Quality of life factors are ambiguous and have different meanings for different people. Therefore, it is difficult to measure quality of life preferences for all high tech professionals. This study selected a very limited set of quality of life indicators. More comprehensive analyses are needed to further explore the relationship between quality of life condition and high tech development in a region. 


\section{Analysis of Agglomeration Economies Factors on}

\section{High Tech Employment Change}

\section{Table 24}

Summary of Agglomeration Economies variables estimating high tech employment, 1998-2001 (t

values are in parentheses)

\begin{tabular}{|l|r|r|}
\hline Variables & DV: High Tech 2001 & DV: High Tech Change \\
\hline AGE & 0.250 & 0.191 \\
& $(5.541)$ & $(3.519)$ \\
& $* * *$ & $* * *$ \\
\hline EDU & 0.228 & 0.018 \\
& $(5.105)$ & $(0.336)$ \\
& $* * *$ & \\
\hline ACADEMIC & 0.207 & 0.384 \\
RESEARCH & $(4.368)$ & $(6.726)$ \\
& $* * *$ & $* * *$ \\
\hline INDUSTRY & 0.045 & 0.000 \\
DENSITY & $(1.102)$ & $(-0.001)$ \\
\hline FORTUNE & 0.274 & 0.208 \\
& $(5.962)$ & $(3.760)$ \\
& $* * *$ & $* * *$ \\
\hline LARGE & 0.086 & -0.046 \\
& $(2.205)$ & $(-0.993)$ \\
\hline R Square & $* *$ & 0.404 \\
\hline R Square Change & 0.588 & 0.029 \\
\hline
\end{tabular}

Notes:

DV: high tech change, means the change of total employment for ten selected high tech sectors in each MSA from 1998 to 2001

DV: high tech 2001, means the total employment for ten selected high tech sectors in each MSA in 2001 (log transformation)

* Significance level $\mathrm{p}<0.1$

** Significance level $p<0.05$

$* * *$ Significance level $\mathrm{p}<0.01$ 
Agglomeration economies theory states that spatial concentrations of related industries in a region produce cost saving effects, and thus improve productivity and innovation. This study compiles the number of high tech establishments per square mile in an MSA to account for local concentrations of high tech enterprises. The numbers of high tech establishments in an MSA in 1998 are from County Business Patterns. The total square miles in an MSA are calculated from the metropolitan shape file, which is downloaded from U.S. Census Bureau. Statistical results show that the number of high tech establishments per square mile has an insignificant correlation with both high tech employment in 2001 and high tech employment change from 1998 to 2001. This finding indicates that high tech employment between 1998 and 2001 could not be explained by local concentrations of high tech firms in an MSA. It is contradicted with MarshallArrow-Romer externalities and does not support localization economies, but is consistent with Glaeser, Kallal, Scheinkman, and Shleifer's study and supports Simmie's argument that economic activities coming from local businesses do not necessarily play a significant role in regional high tech growth (Glaeser, Kallal, Scheinkman, and Shleifer 1992, Simmie, Sennett, Wood, and Hart 2002). It also supports U.S. Office of Technology Assessment's report that localization economies become less important for high tech businesses (OTA 1995).

Another agglomeration variable, at least five Fortune 500 Corporation Headquarters 
in an MSA, is a dummy variable. The existence of Fortune 500 corporate headquarters in a region has been considered an important location factor on high tech development by various studies such as in High Tech America by Markusen, Hall, and Glasmeier in 1986. As expected, the Fortune 500 variable shows strongly, consistently positive coefficients in both models, with the coefficients highly significant at the 99 percent $(\mathrm{P}<0.01)$ confidence levels (see Table 24). Fortune 500 corporations are usually multinational companies, which have extensive business networks with other MSAs and overseas. Its significantly positive relationships with both high tech employment in 2001 and high tech employment change from 1998 to 2001 appear to support Simmie's argument that MSAs with more interregional and international activities going on in the local business system are more attractive to high-tech industries than other regions. Sommers and Carlson (2003) also suggest that regions should build strong business relationships with firms in other regions and countries to establish a partner environment in a globalized economy.

Some scholars claim that small businesses are more innovative than large firms, and metropolitan regions dominated by small firms should have more high tech activities than metropolitan areas with dominance of large establishments. In this study, the percentage of establishments with over 500 employees in an MSA is used to test the relationship between firm size and high tech employment concentration. In Table 24, this variable shows mixed signs - a significant positive relationship with high tech employment in 2001 and an insignificant negative correlation to high tech employment change from 
1998 to 2001. In other words, it does not show the expected significantly negative relationship with dependent variables. The reason may be that economies of scale for a high tech firm is still important for some manufacturing sectors such as the aerospace products and parts manufacturing industry. Mathur (1999) suggests that the combination of small, but high-growth, firms and large, mature establishments in a region ensures a high growth rate with stability. Thus, both large establishments and small firms should have a role to play in regional high tech economic development.

In summary, statistical analyses on agglomeration economies variables suggest that high tech industries prefer metropolitan areas with the presence of Fortune 500 corporation headquarters. This does not mean that high tech firms are looking for the presence of Fortune 500 corporation headquarters for their location decisions. The metropolitan areas with the presence of the Fortune 500 headquarters usually have more business linkages with interregional and international economies, and have more advanced information flow with the world market, which offer high tech industries a favorable business environment for technological innovation and progress. It also encourages local firms to change the way they do business to match the new competitive environment and generate more high tech start-ups. Simmie and other scholars argue that business linkages with other regions and countries is more important than local concentrations of economic activities in promoting local economic development (Simmie, Sennett, Wood and Hart 2002). This seems to suggest that the largest high tech 
metropolitan areas are the regions with more business linkages with interregional and international economies.

\section{Analysis of Weber's Classical Location Theory Factors on \\ High Tech Employment Change}

Weber's Classical location theory states that a firm chooses its optimum location with minimum total transportation cost between the sources of inputs and the output (Weber 1929). Transportation costs is a function of weight and distance. In modern literature, some scholars suggest that transit time is more crucial than transportation cost, itself. High tech industries are very time-intensive. The reduction of production and transaction time is crucial for high tech firms to gain market share. McCann and Sheppard (2003) suggest that demand of short transit times has increased spatial transaction costs for modern high tech firms. Button suggests that major high technology establishments are usually within easy reach of airport facilities. Air transportation is important in virtually all high-tech location decisions (Button 1984). Cohen states that highway density has a positive impact on new manufacturing firm formation and total employment in a region (Cohen 2000). Cortright claims that transportation cost is an important location factor for high tech firms (Cortright 2001b). Ann Markusen, Peter Hall, and Amy Glasmeier (1986) list the presence of an international airport and an advanced transportation network, such as highways, as important production cost factors on high 
tech development.

Table 25

Summary of Classical Location Theory variables estimating high tech employment, 1998-2001 (t

values are in parentheses)

\begin{tabular}{|l|r|r|}
\hline Variables & DV: High Tech 2001 & DV: High Tech Change \\
\hline AGE & 0.079 & 0.098 \\
& $(1.939)$ & $(1.708)$ \\
& $* .204$ & $*$ \\
& $(5.670)$ & 0.092 \\
& $* * *$ & $(1.801)$ \\
& 0.067 & $*$ \\
\hline RESEARCH & $(1.888)$ & 0.316 \\
UNIVERSITY & $*$ & $(6.293)$ \\
& 0.367 & $* * *$ \\
\hline AIRPORT & $(9.560)$ & 0.172 \\
& $* * *$ & $(3.155)$ \\
& 0.363 & $* * *$ \\
\hline WAGE & $(8.059)$ & 0.175 \\
& $* * *$ & $(2.748)$ \\
& 0.707 & $* * *$ \\
\hline R Square & 0.186 & 0.411 \\
\hline R Square Change & & 0.036 \\
\hline
\end{tabular}

Notes:

DV: high tech change, means the change of total employment for ten selected high tech sectors in each MSA from 1998 to 2001

DV: high tech 2001, means the total employment for ten selected high tech sectors in each MSA in 2001 (log transformation)

* Significance level $\mathrm{p}<0.1$

** Significance level $\mathrm{p}<0.05$

$* * *$ Significance level $\mathrm{p}<0.01$

Because the Academic Research variable shows a relatively high correlation of .588 with the Airport variable, I used the UNIV variable, the number of top ranked research universities in an MSA, to replace Academic Research in the following models. In this 
section, I introduce two new variables, the existence of an international airport and the average annual salary in an MSA, to test the effectiveness of location theory on explaining high tech clusters.

By exploring the correlations with dependent variables, I find both airport and highway variables show the expected strongly significantly positive relationships with high tech employment concentrations in 2001 at the 99 percent confidence level. Airport and highway variables show multicollinearity through the SPSS collinearity diagnostic test, and are also highly correlated, with a coefficient equal to 0.7 . In addition, they both represent the transportation infrastructure in a region. In this study, I include the airport and exclude the highway variable from the multivariate regression to represent transportation infrastructure in a region.

The finding shows that the presence of an international airport has expected positive coefficients, and is highly significant at the 99 percent $(p<0.01)$ confidence level in both models (see Table 25). This means that the presence of an international airport in an MSA is highly correlated with both high tech employment in 2001 and high tech employment growth from 1998 to 2001. Airport facilities offer high tech professionals fast transportation availability, thus reducing transaction time for high tech industries. Button (1984) and Markusen, Hall, and Glasmier (1986) suggest the importance of access to airport facilities for high tech firms to reduce transaction time. McCann and Sheppard 
(2003) argue that demand for short transit times has increased spatial transaction costs for modern high tech firms. The analytical finding in this section appear to support the previous literature that transportation cost for high tech firms does not only mean the costs of moving materials to the firm and moving products to market, but also means moving managerial and technical professionals through the fast, high-level transportation facilities such as air travel. The old factors of location advantage, such as closeness to raw materials or railroads will no longer be enough to explain location decisions of high tech industries. The demand for shortening transaction time and providing face-to-face communications among managerial and technical professionals has become very crucial for high tech industries.

Labor cost is one of three primary factors that influence a firm's location decision in Weber's Classical location theory. Weber argues that firms will select a low labor cost region to reduce production costs. Therefore, this study hypothesizes a negative relationship between labor cost and high tech employment growth from 1998 to 2001. I use the average annual salary per employee in an MSA (wages) to represent labor cost. The data are retrieved from the Regional Economic Information System by MSAs. The analytical results in Table 25 indicate that the average annual salary per worker in an MSA is statistically significant at the 99 percent confidence level $(\mathrm{p}<0.01)$ in both models, but the positive signs on the coefficients are the opposite of expectations. This may be explained that higher wages are associated with more retention of technical professionals, 
which are associated with increased productivity in an MSA. High tech firms choose high labor cost regions such as the San Francisco Bay, Boston, and New Jersey to access large pools of knowledge-based labor force.

Analytical findings on Classical location theory variables indicate that high tech industries prefer high labor cost metropolitan areas with access to an international airport. Transportation still plays a very important role in high tech clusters, but has a different form - declining transit time. In other words, transportation does not only mean the costs of moving materials to a firm and moving products to markets; it also means moving managerial and technical professionals through fast, high-level transportation facilities, such as airports. Classical location theory needs to be revised and extended to better explain location behaviors of modern high tech firms.

Analysis of the Creative Cities Factor on High Tech Employment Change

Sir Peter Hall suggests that creative cities are a special kind of cities with large numbers of new and young immigrants, and creativity comes from cultural clashes and structural instability, which leads to new ideas and creative thinking (Hall 2000). Jacobs suggests that diversity of local residents stimulates innovation and generates new ideas (Jacobs 1969, 1984). Florida finds that eight out of the top ten metropolitan regions with the highest percentage of foreign-born population are also among the top fifteen high tech 
regions (Florida 2001). He further defines a special kind of worker - the "Creative Class" - and states that regions with great diversity attract more talented people, or the Creative Class, who promote high tech growth in a region (Florida 2000). Thus, this study hypothesizes a positive relationship between the percentage of foreign-born population in an MSA and high tech employment concentration. In other words, metropolitan areas with high percentage of foreign-born population are more innovative and creative, and thus attract or generate more high tech businesses in a region.

\section{Table 26}

Summary of Creative Cities Theory variables estimating high tech employment, 1998-2001 (t values are in parentheses)

\begin{tabular}{|l|r|r|}
\hline Variables & DV: High Tech 2001 & DV: High Tech Change \\
\hline AGE & 0.322 & 0.197 \\
& $(7.110)$ & $(3.797)$ \\
& $* * *$ & $* * *$ \\
\hline EDU & 0.209 & 0.025 \\
& $(4.464)$ & $(0.461)$ \\
& $* * *$ & \\
\hline ACADEMIC & 0.308 & 0.445 \\
RESEARCH & $(6.511)$ & $(8.169)$ \\
& $* * *$ & $* * *$ \\
\hline FOREIGN_BORN & 0.121 & 0.098 \\
& $(2.770)$ & $(1.938)$ \\
& $* * *$ & $*$ \\
\hline R Square & 0.532 & 0.382 \\
\hline R Square Change & 0.011 & 0.007 \\
\hline
\end{tabular}

Notes:

DV: high tech change, means the change of total employment for ten selected high tech sectors in each MSA from 1998 to 2001

DV: high tech 2001, means the total employment for ten selected high tech sectors in each MSA in 2001 (log transformation)

* Significance level $\mathrm{p}<0.1$

$* *$ Significance level $\mathrm{p}<0.05$

$* * *$ Significance level $\mathrm{p}<0.01$ 
The statistical results in table 26 show significantly positive coefficients for the foreign-born variable in both models, which support the hypothesis. However, the Rsquare change is much lower, 0.011 and 0.007 , respectively. It indicates that the percentage of foreign-born population entering USA from March 1990 to 2000 has had a very limited impact on high tech employment concentration in an MSA between 1998 and 2001. This may be that foreign-born population includes a proportion of refuge, which may have limited role to play in high tech businesses. There is also a lag time before foreign-born professionals could play an active role in high tech economy. The analytical findings in Table 26 could not provide strong support for creative cities theory. More deep and comprehensive analysis on the impact of culture diversity and creativity on high tech spatial concentration are suggested for the future research.

After examining variables for each theory, it is interesting to pull all of the important variables into one equation and to run multivariate regression to test their relative importance in influencing high tech employment concentration. The selected variables were checked for multicollinearity. Through the SPSS collinearity diagnostic test and multicollinearity test, these selected variables do not show any obvious multicollinearity relationship. The equations below show their functions and table 27 details the OLS result for these variables including their standardized coefficients with their $\mathrm{t}$ statistics, significance levels and R square coefficients of determination. 


$$
\begin{aligned}
\mathrm{Y}_{1}= & \alpha+\beta_{1} \text { AGE }+\beta_{2} \text { EDU }+\beta_{3} \text { UNIV }+\beta_{4} \text { ESTD }+\beta_{5} \text { FORTUNE }+\beta_{6} \text { AIR }+ \\
& \beta_{7} \text { FOREIGN }+ \text { error } \\
\mathrm{Y}_{2}= & \alpha+\beta_{1} \text { AGE }+\beta_{2} \text { EDU }+\beta_{3} \text { UNIV }+\beta_{4} \text { ESTD }+\beta_{5} \text { FORTUNE }+\beta_{6} \text { AIR }+ \\
& \beta_{7} \text { FOREIGN }+ \text { error }
\end{aligned}
$$

$\mathrm{Y}_{1}$ : high tech employment in 2001, log transformation

$\mathrm{Y}_{2}$ : high tech employment change between 1998 and 2001

\section{Table 27}

Summary of regression coefficients estimating high tech employment, 1998-2001 (t values are in parentheses)

\begin{tabular}{|l|r|r|}
\hline Variables & DV: High Tech 2001 & DV: High Tech Change \\
\hline AGE & 0.191 & 0.146 \\
& $(4.676)$ & $(2.735)$ \\
& $* * *$ & $* * *$ \\
\hline EDU & 0.262 & 0.099 \\
& $(6.835)$ & $(1.984)$ \\
& $* * *$ & $* *$ \\
\hline RESEARCH & 0.092 & 0.312 \\
UNIVERSITY & $(2.356)$ & $(6.136)$ \\
& $* *$ & $* * *$ \\
\hline INDUSTRY & 0.033 & -0.049 \\
DENSITY & $(0.798)$ & $(-0.922)$ \\
\hline FORTUNE & 0.137 & 0.182 \\
& $(3.019)$ & $(3.083)$ \\
& $* * *$ & $* * *$ \\
\hline AIRPORT & 0.387 & 0.114 \\
& $(8.383)$ & $(1.896)$ \\
& $* * *$ & $*$ \\
\hline FOREIGN- BORN & 0.013 & 0.078 \\
& $(0.309)$ & $(1.422)$ \\
\hline R Square & 0.659 & 0.417 \\
\hline Adjusted R Square & 0.651 & 0.404 \\
\hline
\end{tabular}

Notes:

DV: high tech change, means the change of total employment for ten selected high tech sectors in each MSA from 1998 to 2001

DV: high tech 2001, means the total employment for ten selected high tech sectors in each MSA in 2001 (log transformation)

* Significance level $\mathrm{p}<0.1$

** Significance level $\mathrm{p}<0.05$

$* * *$ Significance level $\mathrm{p}<0.01$ 
The first three variables, AGE, EDU, and RESEARCH UNIVERSITY, are human capital variables. These three variables show strongly positive coefficients to both high tech employment in 2001 and high tech employment change from 1998 to 2001, which is consistent with previous analyses on human capital theory. Industry density, an indicator for localization economies, displays insignificant coefficients with a positive sign to high tech employment in 2001 and a negative sign to high tech employment growth from 1998 to 2001. On the other hand, the FORTUNE variable, the presence of at least five Fortune 500 corporate headquarters in an MSA, shows strongly positive coefficients at the 99 percent $(p<0.01)$ confidence levels to both high tech employment in 2001 and high tech employment growth between 1998 and 2001. It further suggests that local high tech economic activities do not necessarily play a significant role on high tech employment concentration. Moreover, the presence of Fortune 500 corporate headquarters has a strong correlation with high tech concentration, which appears to support Simmie, et al's argument that high tech industries are more concentrated in regions with more business linkages with other regions and countries. The AIRPORT variable, an indicator for the presence of an international airport in a region, shows a strongly positive coefficient to high tech employment in 2001 at the 99 percent $(p<0.01)$ confidence levels. It indicates that transportation still plays a crucial role for high tech concentrations in terms of moving managerial and technical professionals through fast transportation facilities. The percentage of foreign-born population entering the USA between March 1990 and 2000 is the leading indicator for creative cities theory. It has positive but insignificant signs for 
both high tech employment in 2001 and high tech employment change between 1998 and 2001, which brings into question the hypothesis that foreign-born population plays a crucial role for high tech employment concentration between 1998 and 2001.

Overall, these location factors in Table 27 show strong explanatory power with $\mathrm{R}^{2}$ coefficients at 0.66 and 0.42 , respectively, for explaining high tech employment in 2001 and high tech employment change between 1998 and 2001. Among these variables, the presence of a top ranked research university, academic research, the percentage of people between ages 25 and 44, the presence of five Fortune 500 corporation headquarters, and the access to an international airport are primary factors that have strong significant correlations with high tech employment concentration. Of course, there are also other variables excluded from the present study that are responsible for the changes in high tech employment, providing more opportunities for future research. 


\section{CHAPTER 7}

\section{CONCLUSIONS AND RECOMMENDATIONS}

In this last chapter, conclusions and implications for future research are discussed.

\section{Summary and Public Policy Implication}

One of the major findings in this study is the strong positive and significant impact of human capital variables on high tech employment concentration in an MSA. It indicates that human capital plays a strategic role in high tech cluster development. A young and well-educated labor force is a prerequisite factor for high tech economic development in an MSA. Research universities produce new knowledge and stimulate technological progress, and further promote innovation and technology spillovers in a region. Research universities are also breeding grounds for high-skilled technical professionals. College graduates from science and engineering programs have new ideas and high technical skills, and are the direct labor force for high tech firms. The analytical findings from this study strongly support human capital theory's assertion that technological progress is contributed to by rational investments in research and education. 
In terms of public policy, an effective and promising long-term high-tech economic development strategy is to promote human capital development in a region. Government incentives should be directed at the accumulation of human capital and promotion of academic research and education rather than subsidization of physical and financial capital only. State and local governments should give priority to enhancing the research capabilities of local universities and to encourage university-industry linkages to stimulate knowledge flows and commercialization of innovation and scientific discoveries.

Agglomeration economies theory argues that firms belonging to the same sector produce cost saving effects by locating close to each other. This study could not find any significant relationship existing between the number of high tech firms per square mile in an MSA and high tech employment between 1998 and 2001, which questions the hypothesis of localization economies. In other words, the analytical results appear to indicate that high tech clusters do not necessarily come from local concentrations of relevant firms in a region. More interestingly, this study identifies a highly significant (positive) relationship between the existence of at least five Fortune 500 corporation headquarters in an MSA and high tech employment clusters. Fortune 500 corporations are usually multinational companies, which have a large volume of information flow with other regions and countries. This attracts high tech businesses, which need advanced informational flow with the world market. It also encourages local firms to change the 
way they do business to match the new competitive environment and generate more high tech start-ups. Furthermore, Fortune 500 corporations attract advanced business services such as finance and real estate, law firms, accounting, and entertainment into a region, providing business infrastructure for high tech industries. At the very least, the positive relationship between Fortune 500 corporations and high tech employment concentration seems to support Simmie's study that the largest high tech metropolitan areas are regions with more interregional and international business activities going on in the local business systems. It is also consistent with Sommers and Carlson's argument that regions should build strong business relationships with firms in other regions and countries to establish a partner environment in a globalized economy (Sommers and Carlson 2003). However, Simmie and other scholars studied only a few European cities. This study conducts analysis at the metropolitan levels in a relatively short time frame. The impact of Fortune 500 corporations or multinational companies on high tech industrial clusters needs more intensive study and testing using a larger sample. In terms of public policy, state and local governments should propose economic development strategies targeted on strengthening business communications and linkages with other regions in addition to purely local networking approaches.

Classical location theory proclaims that transportation cost is the most important factor to a firm in choosing a location. The statistical analysis in the present research finds a highly significant and positive association between the presence of an 
international airport and high tech employment concentration between 1998 and 2001. It supports the hypothesis that transportation still plays a very important role on the spatial allocations of high tech industries. However, for high tech firms, transportation costs does not only mean the costs of moving materials to a firm and moving products to markets; it means moving managerial and technical professionals through fast, high-level transportation facilities such as air travel. Furthermore, the demand for shortening transaction time has become much more crucial for high tech industries. The Weberian triangle assumes that transportation cost is a function of weight and distance, and determines a firm's optimum location by the minimal transportation costs between the inputs (goods) and the output. Weberian location theory works well for the locations of heavy manufacturing industries in the nineteenth and early twentieth century, but may not explain well the locations of high tech businesses. Classical location theory needs to be revised to address location behaviors of modern high-tech enterprises.

Creative cities theory states that creativity comes from cultural clashes and structural instability. Creative cities with a large percentage of young people and immigrants generate new ideas and stimulate innovative activities, thus promoting high tech economic development in a region. From creative cities theory, we could hypothesize that metropolitan areas with a high percentage of foreign-born population experience more high tech employment growth than others. However, the statistical results in the present study indicate that the percentage of foreign-born population has only a modest impact on 
high tech employment concentration between 1998 and 2001. This study could not provide strong support for creative cities theory.

In summary, the findings from these regressions in the previous chapter may suggest that successful high technology regions are the regions with the presence of research universities with strong academic research capabilities, a young and welleducated labor force, accessibility to an international airport, and the presence of multiregional and multinational corporate headquarters. This supports human capital theory, which holds that expenditure on academic research and education has a positive impact on high tech employment concentration. It is also consistent with Simmie and other scholars' argument that the largest high tech regions are the regions with close ties to businesses in other regions and countries. In addition, this study could not find any significant relationship between local concentration of high tech firms and high tech employment concentration, which questions the hypothesis of localization economies.

\section{Limitation and Recommendations for Future Research}

The research findings in this dissertation are preliminary, and leave open several directions for future research. 
First, location studies on high-tech industries should consider the specific features for the specific industrial sector. High tech industries differ in their sensitivity to regional attributes. Some industries are more dependent on skilled labor and access to market, such as the computer system design industry. Other industries including aerospace, computers manufacturing and software industry are subject to increasing returns since they require large initial investments in research, design, and development but relatively low reproduction costs - more difficult during the design and development phase and relatively easier to reproduce. It is better to analyze the importance of location factors on high tech clusters in each industrial sector. Unfortunately, there are currently only four years of high tech employment data available by NAICS code from County Business Patterns, which precludes a more detailed and extensive analysis of the space-time dynamics. More work and research should be done in the future when long-range data become available.

Second, since this study concerns the entire high tech industry, the calculation does not distinguish innovative functions such as research and development from production facilities, like assembly-line plants in the same high tech sector. Occupation data classify high tech employment by technical occupations, which offer more accurate datasets for innovative high tech workers. However, the occupation database from the Bureau of Labor Statistics does not separate high tech occupations by industrial sectors. We need to have more detailed data classified by both occupation and industrial sectors to better 
understand the differential spatial patterns of different segments in each high tech industry.

Third, high tech industries have different location behaviors compared to those of traditional heavy manufacturing industries because high tech firms are critically dependent on skilled technical professionals. Deeper studies on the organization and transaction processes of high-tech industries should be conducted in order to better understand their spatial allocation and growth patterns and to revise or enrich location theories.

Fourth, there are great variations of high tech industrial development among the metropolitan regions. This study does not distinguish high-tech regions from low-tech regions. A comparative study of the metropolitan areas by high-tech and low-tech regions may offer more interesting results. In addition, more detailed research, such as case studies on the top-ranked high tech regions, is recommended in future studies.

Fifth, this study does not mention non-market institutions or non-profit organizations, which seem to play a crucial role in the working of high tech clusters. Regions are different in their capacity to assimilate and transfer local innovations into economic activities. Local social structures such as the role of social institutions and non-profit organizations have been increasingly recognized as playing a significant role in the 
openness of any regions to innovation. There is a need to conduct further research on institutional and political aspects to better understand the interactions between innovation and society and how they affect a region's capacity to assimilate innovation and transform it into local economic activities.

Sixth, the strongly significant coefficients of variables and relatively high $\mathrm{R}^{2}$ across the models indicate strong explanatory powers of primary factors included in the present research on high tech employment growth. However, location of high-tech industries covers a wide range of considerations. The factors listed in this study are far from complete. There are also other factors that represent the four theories or may have an impact on the selected variables, which are not identified by the present study or the data are difficult to collect. There may be causal direction and spurious relationship problems among the selected independent variables. The causal direction problem means that some independent variables may be influenced by total high tech employment in 1998, which affect their interpretations on the impact of high tech employment in 2001. For instance, high tech industrial concentration may attract educated professionals into the region for more career opportunities. In this way, the initial high tech employment concentration may contribute to the growth of educated professionals in a region. In addition to causal directions, some variables may have spurious relationships with the dependent variables. One example is the Fortune 500 corporate headquarters. As I mentioned in Chapter 6, the significant relationship between the presence of Fortune 500 corporation headquarters 
and high tech employment concentration does not mean that high tech firms are looking for the presence of Fortune 500 corporation headquarters for their location decisions. Both high tech firms and Fortune 500 corporation headquarters may favor a similar business environment - a more open economy with more business linkages with other regions and countries, more advanced information flows with the world market, and the advanced business services such as finance, real estate, accounting, law firms, and entertainment. In other words, the Fortune 500 corporate headquarters has a co-location relationship with high tech activities in a region, not a causal relationship. In terms of these limitations, more comprehensive analysis of location factors for high tech industries are recommended in the future research to enhance our understanding of high tech location theory.

This dissertation is a preliminary study on location theories of high tech economic development. It raises more questions, providing fertile ground for future research. 


\section{REFERENCES}

Acs, Z. J., \& Audretsch, D. B. (1990). Innovation and Small Firms. MIT Press, Cambridge, MA.

Acs, Z. J., Audretsch, D. B., \& Feldman, M. P. (1994). R\&D Spillovers and Recipient Firm Size Review of Economics and Statistics. 76: 336-340

Adams, James D., \& Jaffe, Adam B. (1996). Bounding the Effects of R\&D: An

Investigation Establishment-Firm Data Rand Journal of Economics, 27(4), 700-721.

Aghion, P. \& Howitt, P. (1993). A Model of Growth Through Creative Destruction. Econometrica. Vol. 60, 323-351.

Almedia, P., \& Kogut, B. (1997). The Exploration of Technological Diversity and the Geographic Localization of Innovation. Small Business Economics. 9, 21-31

Amin, Ash. (1999). An institutionalist perspective on regional economic development. International Journal of Urban and Regional Research. Vol. 23, 365-378.

Andersson, A.E. (1985). Creativity and regional development. Papers of the Regional Science Association. 56: 5_20.

Anselin, Luc, Varga, Attila \& Acs, Zoltan. (1997). Local Geographic Spillovers Between University Research and High Technology Innovations. Journal of Urban Economics. Vol 42, 422-448 
Antonelli, C. (1990) Induced adoption and externalities in the regional diffusion of information technology. Regional Studies 24: 31-40.

Armington, C. (1986). Entry and Exit of Firms: An International Comparison. Mimeo. Brookings Institution.

Arthur, W. Brian. (1989). “Competing technologies, increasing returns and lock-in by historical events". The Economic Journal 99: 116-131

Audretsch, D. B. \& Feldman, M. (1996). R\&D spillovers and the geography of innovation and production. American Economic Review. 86: 630-640

Arrow, K. (1962). Economic welfare and the allocation of resources for invention, in The Rate and Direction of Inventive Activity by R. Nelson, ed., Princeton University Press, Princeton, NJ

Atkinson, Robert D., \& Gottlieb, Paul D. (2001). The Metropolitan New Economy Index: Benchmarking Economic Transformation in the Nation's Metropolitan Areas.

Washington D.C.: Progressive Policy Institute.

Audretsch, David B., Leeuwen, Geoge van, Menkveld, Bert, \& Thurik, Roy. (2001).

Market dynamics in the Netherlands: competition policy and the response of small firms. International Journal of Industrial Organisation. Vol. 19: 795-821

Aydalot, P. (ed.) (1986). Milieux Innovatuers en Europe. Paris: CEE.

Aydalot, P. and Keeble, D. (eds) (1988). High Technology Industries and Innovative Environments: The European Experience, London: Routledge.

Bania, N., Calkins, L. N., \& Dalenberg, D. R. (1992). The effects of regional science and technology policy on the geographic distribution of industrial R \& D labs, Journal of Regional Science, 32: 209-228 
Bania, N., Eberts, R. \& Fogarty, M. S. (1993). Universities and the startup of new companies: Can we generalize from Route 128 and Silicon Valley? The Review of Economics and Statistics, 75: 761-766.

Barro, R. J. (1992). Human capital and economic growth. in Policies for long-run economic growth, a symposium sponsored by the Federal Reserve Bank of Kansas City, Jackson Hole, WY. 99-216. Kansas City, MO: Federal Reserve Bank of Kansas City. August 27-29.

Bartel, A. and Lichtenberg, F. (1987). The comparative advantage of educated workers in implementing new technology, The Review of Economics and Statistics, 69: 1-11.

Bartik, T. J. (1991). Who Benefits from State and Local Economic Policies? Kalamazoo, Michigan: W.E. Upjohn Institute for Employment Research.

Bates, T. (1990) Entrepreneur human capital inputs and small business longevity. Review of Economics and Statistics. 72: 551-559.

Beardsell, M. and Henderson, J. V. (1999). Spatial evolution and the computer industry in the USA. European Economic Review. 43: 431-456.

Beeson, P. (1987). Total Factor Productivity Growth and Agglomeration Economies in Manufacturing, 1959-73. Journal of Regional Science, 27: 753-761

Beeson, P. \& Montgomery, E. (1993). The Effects of Colleges and Universities on Local Labor Markets. Review of Economics and Statistics. 75: 753-761

Belleflamme, Paul, Picard, Pierre, \& Thisse, Jacques-Francois. (2000). An Economic Theory of Regional Clusters. Journal of Urban and Economics. 48: 158-184.

Black, Duncan \& Henderson, Vernon. (1999). A Theory of Urban Growth. Journal of Political Economy. Vol. 107, No. 2. by the University of Chicago. 
Black, S. E. \& Lynch, L. M. (1996). Human capital investment and productivity. American Economic Review. 86: 263-267

Blair, J. P. and Premus, R. (1987). Major factors in industrial location: a review. Economic Development Quarterly 1: 72-85.

Blakely, Edward J. (2001). Competitive Advantage for the $21^{\text {st }}$ Century: Can a PlaceBased Approach to Economic Development Survive in a Cyberspace Age? Journal of the American Planning Association 67(2): 133-140

Bradbury, K. L., Kodrzycki, Y. K., \& Tannenwald, R. 1997. The Effects of State and Local Public Policies on Economic Development: An Overview. New England Economic Review. March/April. 1-12

Button, Kenneth. (1984). Road Haulage Licensing and EC Transport Policy, Gower, Aldershot.

Button, Kenneth. (1988). High-Technology Companies: An Examination of their Transport Needs. New York: Pergamon Press Inc.

Camagni, R. (ed.) (1992). Innovation Networks: The Spatial Perspective, London: Belhaven/Frances Printer.

Carton, D. W. (1997). Why men locate where they do: An econometric model. In W. C. Wheaton (Ed.) Interregional movement and regional growth. 13-50. Washington, DC: Urban Institute.

Ciccone, A. \& Hall, R. E. (1996). Productivity and the density of economic activity. American Economic Review. 86: 54-70.

Clinitz, B. (1961). Contrasts in Agglomeration: New York and Pittsburg. American Economic Review. 51: 279-289. 
Cohen, W. M. \& Levinthal, D. A. (1989). Innovation and Learning. The Economic Journal, 99: 569-596.

Cohen, Natalie. (2000). Business Location Decisions-Making and the Cities: Bringing Companies Back. Washington D.C.: The Brookings Institution. April.

Cortright, Joseph. (2001a). New Growth Theory: Some Thoughts and Implications for Economic Development. Impresa, Inc.

Cortright, Joseph. (2001b). Transportation, Industrial Location, and the New Economy: How Will Changes in Information Technology Change the Demand for Freight Transportation and Industrial Location? Impresa, Inc. March.

Cortright, Joseph. (2002). The Economic Importance of Being Different: Regional Variations in Tastes, Increasing Returns, and the Dynamics of Development. Economic Development Quarterly. 16 (1): 2-16.

Cortright, Joseph. \& Mayer, Heike. (2001). High Tech Specialization: A Comparison of High Technology Centers. The Brookings Institution, Center on Urban and Metropolitan Policy.

Davenport, T.O. (1999). Human Capital: What It Is and Why People Invent It. San Francisco: Jossey-Bass.

De Vet, J. M. (1990). Innovation and new firm formation in southern California's medical device industry. MA thesis, UCLA, Department of Geography.

DeLong B. \& Summers, L. (1991). Equipment Investment and Economic Growth. Quarterly Journal of Economics. Vol. 106: 445-502.

DeVol, Ross. (1999). America’s High Tech Economy: Growth, Development and Risks for Metropolitan Areas. Santa Monica, CA, Milken Institute: 127 
Dorfman, N. (1983). Route 128: The Development of a Regional High Technology

Economy. Research Policy. 12: 299-316.

Dosi, G. (1988) Sources, procedures and microeconomic effects of innovation. Journal of Economic Literature, 26: 1120-1171

DRI/McGraw-Hill. (2000). U.S. Industry \& Trade Outlook 2000. Standard \& Poor's, U.S. Department of Commerce/International Trade Administration.

Dumais, Guy, Ellison, Glenn \& Glaeser, Edward L. (2002). Geographic Concentration As a Dynamic Process. The Review of Economics and Statistics. May. 84(2): 193-204.

Duranton, G. and Puga, D. (1999). Nursery Cities. London School of Economics, mimeo. Ellison, Glenn., Dumais, Guy, \& Glaeser, Edward L. (1997). Geographic concentration as a dynamic process, NBER working paper 6270.

Feagin, J. R. and Smith, M. P. (1987). Cities and the New International Division of Labor: an Overview. In M. P. Smith and J. R. Feagin (eds). The Capitalist City. Oxford: Basil, Blackwell 3-34.

Federal Bureau of Investigation. Uniform Crime Reports. (1999) Crime in the United States 1998. October 17. Washington DC: Federal Bureau of Investigation. Feldman, M. (1994a). The Geography of Innovation Kluwer Academic, Boston Feldman, M. (1994b). The University and Economic Development: the Case of Johns Hopkins University and Baltimore. Economic Development Quarterly. 8(1), 67-76 Feldman, M.P. and Audretsch, D.B. (1999). Innovation in Cities: Science-based Diversity, Specialization and Localized Competition. European Economic Review 43 (2), 409-429. 
Feser, Edward J. (2001). A Flexible Test for Agglomeration Economies in Two US Manufacturing Industries. Regional Science and Urban Economies. 31: 1-19.

Feser, Edward J. (2002). Tracing the sources of local external economies. Urban Studies. 39 (13), 2485-2506.

Florax, R. (1992). The University: A Regional Booster? Economic Impacts of Academic Knowledge Infrastructure. Avebury, Aldershot.

Florax, R. \& Folmer, H. (1992). Knowledge Impacts of Universities on Industries: An Aggregate Simultaneous Investment Model. Journal of Regional Science. 32: 437-466. Florida, Richard L. (2000). Competing in the Age of Talent: Environment, Amenities, and the New Economy. Prepared for the R.K. Mellon Foundation, Heinz Endowments, and Sustainable Pittsburgh.

Florida, Richard L. (2001). Technology and Tolerance: The Importance of Diversity to High-Technology Growth. Washington, D.C.: The Brookings Institution. June 2001. Florida, Richard L. (2002). The Rise of the Creative Class: how it's transforming work, leisure, community and everyday life. New York, NY: Basic Books.

Fogarty, M. \& Garofalo, G. 1988. Urban Spatial Structure and Productivity Growth in the Manufacturing Sector of Cities. Journal of Urban Economies, 23: 60-70.

Fogarty, M. S., \& Sinha, A. K. (1999). Why Older Regions Can’t Generalize From Route 128 and Silicon Valley: University-Industry Relationships and Regional Innovation Systems. In R. Florida (Ed.), Industrializing Knowledge: University-Industry Linkages in Japan and the United States. Cambridge, MA: MIT Press.

Frenkel, Amnon. (2001). Why High-technology Firms Choose to Locate in or near Metropolitan Areas. Urban Studies, Vol. 38, No. 7, 1083-2202 
Fulton, William \& Shigley, Paul. (2001). Little Chips, Big Dreams. Governing. May. Glaeser, Edward L., Scheinkman, Jose A., \& Shleifer, Andrei. (1995). “Economic Growth in a Cross-Section of Cities". Journal of Monetary Economics, 36: 117-143. Glaeser, Edward L. (1994). Cities, information, and economic growth. Cityscape. Vol. 1, $9-48$

Glaeser, Edward L. (1998). Are Cities Dying? Journal of Economic Perspectives, 12: $139-160$.

Glaeser, Edward L. (1999a). The Future of Urban Research: Non-Market Interactions. working paper, Harvard University.

Glaeser Edward L. (1999b). Learning in Cities. Journal of Urban Economics. 46, 254277

Glaeser, Edward L. (2000). The New Economics of Urban and Regional Growth. In Gordon Clark, Meric Gertler, and Maryann Feldmen (eds). The Oxford Handbook of Economic Geography. Oxford: Oxford University Press, 83-98.

Glaeser, E. \& Shapiro, J. M. (2001). City Growth and the 2000 Census: Which Places Grew, and Why. Brookings Institution. May.

Glaeser, E., Kallal, H., Scheinkman, J., \& Shleifer, A. (1992). Growth in cities. Journal of Political Economy, 100: 1126-1152.

Glasmeier, A. (1991). The High-Tech Potential: Economic Development in Rural America. New Brunswick, NJ: Center for Urban Policy Research.

Goe, W. R. (1991). The growth of producer services industries: sorting through the externalization debate. Growth and Change. 22: 118-141. 
Goldberg, C. (1999). Across the US Universities are Fueling High Tech Booms. New York Times. New York. Oct. 8.

Goodstein, Eban. (1999). The Trade-Off Myth: Fact and Fiction about Jobs and the Environment. Washington, D.C.: Island Press.

Goldstein, G. \& Gronberg, T. (1984). Economies of scope and economies of agglomeration. Journal of Urban Economics. 16: 91-104.

Gottlieb, Paul D. (1994). Amenities as economic development tools: is there enough evidence? Economic Development Quarterly 8: 270-285. Gottlieb, Paul D. (1995). Residential Amenities, Firm Location and Economic Development. Urban Studies. 32 (9): 1413-1436.

Granger, Maury D. \& Blomquist, Glenn C. (1999). Evaluating the Influence of Amenities on the Location of Manufacturing Establishments in Urban Areas. Urban Studies 36 (11): 1859-1873.

Granovetter, M. (1985). "Economic action and social structure: the problem of embeddedness". American Journal of Sociology 93(3): 481-510.

Gray, M., Golob, E., \& Markusen, A. (1996). Big Firms, Long Arms, Wide Shoulders: The 'hub-and-spoke' Industrial District in the Seattle Region. Regional Studies. 30(7), $651-666$

Griliches, Z. (1979). Issues in assessing the contribution of $\mathrm{R} \& \mathrm{D}$ to productivity growth, Bell Journal of Economics, 10: 92-116 .

Griliches, Z. (1990). Patent statistics as economic indicators: A survey. Journal of Economic Literature, 28: 1661-1707. 
Griliches, Z. (1992). The Search for R \& D Spillovers. Scandinavian Journal of Economics, 94: 29-47.

Grossman, G. \& Helpman, E. (1991). Comparative Advantage and Long-Run Growth. American Economic Review. Vol. 80: 796-815.

Hall, Peter. (1998). Cities in Civilization. Pantheon Books. New York.

Hall, Peter. (2000). Creative Cities and Economic Development. Urban Studies, Vol. 37, No. 4: 639-649.

Harding, C. F. (1989). Location Choices for Research Labs: A Case Study Approach. Economic Development Quarterly. 3: 223-234.

Haug, Peter. (1991). The Location Decisions and Operations of High Technology Organizations in Washington State. Regional Studies 25 (6): 525-541.

Head, Keith, Ries, John \& Swenson, Deborah. (1995). Agglomeration Benefits and Location Choice: Evidence from Japanese Manufacturing Investments in the United States. Journal of International Economics 38 (3-4), 223-247.

Hecker, Daniel. (1999). High-technology employment: a broader view. Monthly Labor Review. June: 18-28.

Helsley, R. W., \& Strange, W. C. (1990). Agglomeration economies and matching in a system of cities. Regional Science and Urban Economics. 20, 189-212.

Henderson, J. Vernon. (1974). The sizes and types of cities. American Economic Review 64: 640-656.

Henderson, J. Vernon. (1977). Economic theory and the cities. New York: Academic Press. 
Henderson, J. Vernon. (1986). Efficiency of Resource Usage and City Size. Journal of Urban Economies. 19, p. 47-70

Henderson, J. Vernon. (1988). Urban development. Theory, fact and illusion. Oxford: Oxford University Press.

Henderson, J. Vernon. (1997). Externalities and Industrial Development. Journal of Urban Economics. 42: 449-470.

Henderson, J. V., Kuncoro, A. and Turner, M. (1995). Industrial development in cities. Journal of Political Economy. 103: 1067-1085

Hoover, Edgar M. (1948). The Location of Economic Activity. McGraw-Hill Book Company, New York.

Howells, J. (1984). The Location of Research and Development. Regional Studies. 18: $13-29$.

Jacobs, Jane. (1969). The Economy of Cities. New York: Vintage. Jacobs, Jane. (1984). Cities and the Wealth of Nations. New York: Random House. Jaffe, Adam B. (1989). Real Effects of Academic Research. The American Economic Review. Vol. 79, No. 5, 957-970. December.

Jaffe, Adam B. \& Trajtenberg, M. (1993). Geographic Localization of Knowledge Spillovers as Evidenced by Patent Citations. Quarterly Journal of Economies, 108: 557598.

Koo, Jun. (2003). When Technology Spillovers are Localized: Importance of Regional and Industrial Attributes. Dissertation. University of North Carolina at Chapel Hill. Krugman, Paul. (1991a). Increasing Returns and Economic Geography. Journal of Political Economy. Vol. 99: 483-499. 
Krugman, Paul. (1991b). Geography and Trade. MIT Press, Cambridge, MA.

Krugman, Paul (1991c). History versus expectations. Quarterly Journal of Economics. 106: 651-667.

Lee, Chong-moon, Miller, William F., Hancock, Marguerite Gong, \& Rowen, Henry S. (2000). "The Silicon Valley Habitat" in The Silicon Valley Edge, edited by Lee, Chongmoon, Miller, William F., Hancock, Marguerite Gong, and Rowen, Henry S. Stanford University Press, Stanford, CA.

Lloyd, P. E. \& Dicken, P. (1977). Location in space, a theoretical approach to economic geography. Second edition. Harper \& Row, London.

Lucas, Robert E. (1988). On the Mechanics of Economic Development. Journal of Monetary Economics. 22: 3-42.

Luger, M. I., \& Goldstein, H. A. (1991). Technology in the Garden. Chapel Hill: University of North Carolina at Chapel Hill Press.

Lund, L. (1986). Locating Corporate R \& D Facilities. Conference Board Report No. 892, The Conference Board, New York.

Maillat D., Crevoisier, O. and Lecoq, B. (1990). Innovation and territorial dynamism. paper for workshop Flexible Specialization in Europe. Zurich, 25-26 October Malecki, Edward J. (1980). Corporate organization of R\&D and the location of technological activities. Regional Studies. 14, 219-235.

Malecki, Edward J. (1986). Research and development and the geography of hightechnology complexes, in Technology, Regions and Policy by J. Rees, ed., Rowman and Littlefield, Totowa, $\mathrm{NJ}$ 
Malecki, Edward J. (1991). Technology and Economic Development. Longman Scientific and Technical, Essex

Malecki, Edward J. (1997). Technology and Economic Development, the Dynamics of Local, Regional and National Competitiveness. Longman: Essex, England. Malecki, Edward J. (1999). Knowledge and Regional Competitiveness. Paper prepared for presentation at the International Symposium, Knowledge, Education and Space, Heidelberg, Germany. September.

Malmberg, A., Solvell, O., \& Zander, I. (1996). Spatial clustering, local accumulation of knowledge and firm competitiveness. Geografiska Annaler, 78B, 85-97. Mansfield E. J. (1991). Academic Research and Industrial Innovation. Research Policy. 20: $1-12$.

Markusen, Ann. (1986). Sticky places in slippery space: a typology of industrial districts. Economic Geography. 72: 293-313

Markusen, Ann, Hall, Peter, \& Glasmeier, Amy. (1986). High Tech America: The What, How, Where, and Why of the Sunrise Industries. Boston, London, Allen and Unwin.

Marshall, A. (1890). Principles of Economics. London: Macmillan. $8^{\text {th }}$ edition published in 1920 .

Martin, R. \& Sunley, P. (1998). Slow Convergence? The New Endogenous Growth Theory and Regional Development. Economic Geography. Vol. 74, 201-227.

Mathur, V. K. (1999). Human capital-based strategy for regional economic development. Economic Development Quarterly. Vol. 13, No. 3, 203-216. August.

Mayer, H. (2003) Taking root in the Silicon Forest: The role of high technology firms as surrogate universities in Portland, Oregon. Unpublished dissertation, Portland State 
University, Portland, OR.

McCann, Philip. (1995). Rethinking the economies of location and agglomeration. Urban Studies. 32: 563-577.

McCann, Philip \& Sheppard, Stephen. (2003). The Rise, Fall and Rise Again of Industrial Location Theory. Regional Studies. Vol. 37. 6\&7, 649-663 Aug/Oct.

Micklethwait, J. (1997). Future perfect? A survey of Silicon Valley. The Economist. March 29.

Moomaw, R. L. (1981). Productivity and city size: A critique of the evidence. Quarterly Journal of Economics. 96: 675-688.

Moomaw, R. L. (1988). Agglomeration Economies: Localization or Urbanization? Urban Studies, 25: 150-161.

Myers, D. (1987). Community-relevant measurement of quality of life: a focus on local trends. Urban Affairs Quarterly 23: 108-125.

Nahm, K. B. and Semple, R. K. (1993). The Changing System of Multinational Corporate Linkages, 1974-1991. Paper presented at the PCAG meeting, Riding Mountains, MAN. Nakamura, R. (1985) Agglomeration economies in urban manufacturing industries: A case of Japanese cities. Journal of Urban Economics. 17. 108-124.

Napier, David H. (1998). Aerospace Statistics: 1998 Year-end Review and Forecast. Aerospace Industries Association Napier, David H. (1999). Aerospace Statistics: 1999 Year-end Review and Forecast. Aerospace Industries Association Nardinelli, C. \& Simon, C. (1992). Information and the rise of cities: Evidence from American urban history. Working paper. 
Nelson, R. (1959). The simple economics of basic scientific research, Journal of Political Economy, 67: 297-306.

Nelson, R. (1982). The role of knowledge in R \& D efficiency. Quarterly Journal of Economics, 97: 453-470

Nelson, R. (1986). Institutions Supporting Technical Advance in Industry. American Economic Review. 76: 186-189.

North, C. Douglass. (1955). Location theory and regional economic growth. Journal of Political Economy. LXIII, 243-258.

Parker, D. D. \& Zilberman, D. (1993). University Technology Transfers: Impacts on Local and U.S. Economies. Contemporary Policy Issues. 11: 87-99.

Paytas, Jerry., Gradeck, Robert \& Andrews, Lena. (2004). Universities and the Development of Industry Clusters. Prepared for Economic Development Administration, U.S. Department of Commerce. Carnegie Mellon University, Center for Economic Development, Pittsburgh, PA.

Perloff, Harvey S. \& Wingo, Lowden. (1961). Natural Resource Endowment and Regional Economic Growth. In J.J. Spengler, ed., Natural Resources and Economic Growth, Washington, D.C.: Resources for the Future.

Porter, Michael E. (1990). The Competitive Advantage of Nations. London: Macmillan. Porter, Michael E. (2000). Location, Competition, and Economic Development: Local Clusters in a Global Economy. Economic Development Quarterly 14 (1).

Premus, R. (1982). Location of High Technology Firms and Regional Economic Development. Staff paper prepared for the Sub-Committee on Monetary and Fiscal Policy of the Joint Economic Committee, US Congress. 
Putnam, Robert D., Nanetti, Raffaella Y., \& Leonardi, Robert. (1993). Making

Democracy Work: Civic Culture and Regional Government in Contemporary Italy.

Princeton, NJ, Princeton University Press.

Quigley, John M. (1998). Urban diversity and economic growth. Journal of Economic Perspectives. 12: 127-138.

Rauch, James. E. (1993). Productivity Gains from Geographic Concentration of Human Capital: Evidence from the Cities. Journal of Urban Economics. Vol. 34, 380-400.

Rees, J. \& Stafford, H. (1986). Theories of Regional Growth and Industrial Location: Their Relevance for Understanding High-tech Complexes. In J. Rees (ed.), Technology, Regions and Policy. Totowa, NJ: Rowman and Littlefield.

Rodriguez-Pose, Andres. (1999). Innovation Prone and Innovation Averse Societies: Economic Performance in Europe. Growth and Change. Vol. 30, 75-105

Rogers, E.M. (1986). The Role of the Research University in the Spin-off of Hightechnology Companies. Technovation 4: 169-81.

Romer, P. M. (1986). Increasing Returns and Long-run Growth. Journal of Political Economy. Vol. 94, 1002-1037

Romer, P. M. (1990). Capital, Labor and Productivity. Brookings Papers on Economic Activity: Microeconomics, p. 337-367.

Rondinelli, Dennis A. (1998). The Changing Forces of Urban Economic Development: Globalization and City Competitiveness in the $21^{\text {st }}$ Century. Cityscape 3 (3). Rosenberg, R. (1985). What companies look for. High Technology. 5: 30-37 Rosenthal, Stuart S. \& Strange, William C. (1999) Geography, industrial organization and agglomeration. Center for Policy Research Working Paper 14, Syracuse University. 
Rosenthal, Stuart S. \& Strange, William C. (2001). The Determinants of Agglomeration. Journal of Urban Economies. 50: 191-229.

Salvesen, David \& Renski, Henry. (2002). The Importance of Quality of Life in the Location Decisions of New Economy Firms. Reviews of Economic Development Literature and Practice. No. 15, report prepared for Economic Development Administration, U.S. Department of Commerce. September. Sassen, Saskia. (1991). The Global City: New York, London, Tokyo. Princeton, NJ: Princeton University Press.

Saxenian, Annalee. (1994). Regional Advantage: Culture and Competition in Silicon Valley and Route 128. Cambridge, MA: Harvard University Press.

Schmenner, R. (1982). Making Business Location Decisions. Englewood Cliffs, NJ, Prentice Hall.

Scott, A. J. (1986). Industrial organization and location: division of labor, the firm, and spatial process. Economic Geography. 63: 215-231.

Segedy, J. (1997). How important is 'quality of life' in location decisions and local economic development? Dilemmas of Urban Economic Development: Issues in Theory and Practice. Richard, B. and R. Myers (eds). Thousand Oaks, Sage Publications. 47. Simmie, James, Sennett, James, Wood, Peter, \& Hart, Doug. (2002). Innovation in Europe: A Tale of Networks, Knowledge and Trade in Five Cities. Regional Studies. Vol. $36(1), 47-64$

Simmie, James. (2003). Innovation and Urban Regions as National and International Nodes for the Transfer and Sharing of Knowledge. Regional Studies. 37.(6-7), 607-620. 
Simon, Curtis J. (1997). Human Capital and Metropolitan Employment Growth. Journal of Urban Economics. Vol. 43, 223-243

Simon, Curtis J. and Nardinelli, C. (1996). The talk of the town: Human capital, information, and the growth of English cities, 1861 to 1961. Explorations in Economic History. 33: 384-413.

Sivitanidou, R. \& Sivitanides, P. (1995). The intrametropolitan distribution of R \& D activities: Theory and empirical evidence, Journal of Regional Science, 35, 391-415 Smith, Donald F., \& Florida, Richard. (1994). Agglomeration and industrial location: An econometric analysis of Japanese-affiliated manufacturing establishment in automotiverelated industries. Journal of Urban Economics, 36:23-41.

Sommers, Paul and Daniel Carlson. (2003). What the IT Revolution Means for Regional Economic Development. The Brookings Institution, Center on Urban and Metropolitan Policy. February 2003.

Stafford, H. (1983). The effects of environmental regulations on industrial locations. Working paper, University of Cincinnati.

Stokey, N. (1991). Human Capital, Product Quality and Growth. Quarterly Journal of Economics. 106, 587-607.

Sveikauskas, L. (1975). The productivity of cities. Quarterly Journal of Economies. 89, $393-413$

Taylor, H. (1987). Evaluating our quality of life. Site Selection 156: 1-4.

Todtling, F. (1992) Technological change at the regional level: The role of location, firm structure, and strategy. Environmental and Planning A, 24: 1565-1584 
U.S. Congress, Office of Technology Assessment (OTA). (1995). The Technological Reshaping of Metropolitan America. Washington, DC: U.S. Government Printing Office. September.

Van Soest, Dann P., Gerking, Shelby D. and van Oort, Frank G. (2002). Knowledge Externalities, Agglomeration Economies, and Employment Growth in Dutch Cities. Discussion paper. CentER. Varga, Attila. (2000). Local academic knowledge transfers and the concentration of economic activity. Journal of Regional Science. 40: 289-309.

Vaughan, Roger and Robert Pollard. (1986). State and Federal Policies for HighTechnology Development in Technology, Regions and Policy. New Jersey: Rowman \& Littlefield.

Vernon, R. (1966). The Myth of Urban Problems. Boston: Harvard University Press. Von Hippel, E. (1988) The Sources of Innovation. Oxford University Press, New York. Weber, Alfred. (1929). Theory of the Location of Industries. Chicago: University of Chicago Press.

Wheeler, D. \& Mody, A. (1992). International investment location decisions: the case of U.S. firms. Journal of International Economics, 33: 57-76

Wong, C. (2001). The relationship between quality of life and local economic development: an empirical study of local authority areas in England. Cities 18(1): 25-32 Zook, Matthew A. (2001). Hubs, Nodes, and Bypassed Places: A Topology of Ecommerce Regions in the United States. Public Policy Institute of California and University of Kentucky. November. 
Zucker, Lynne G., Darby, Michael R. \& Armstrong, Jeff. (1994). Intellectual Capital and the Firm: the Technology of Geographically Localized Knowledge Spillovers. National Bureau of Economic Research, Cambridge, MA.

Economic Report of the President (No. 104). United States Government Printing

Office. Washington D.C. 2000.

The New Spatial Order? Technology and Urban Development: 2001 Annual

Roundtable. Lincoln Institute of Land Policy. Cambridge, MA 2001 


\section{CURRICULUM VITAE}

NAME: $\quad$ Songmei Li

ADDRESS: $\quad$ Department of Urban and Public Affairs

University of Louisville

Louisville, KY 40208

DOB: $\quad$ Harbin, Heilongjiang Province, PR China - June 14, 1970

EDUCATION: $\quad$ BS, Geography

Northeast Normal University, Changchun, China

1988-1992

MS, Human Geography

East China Normal University, Shanghai, China

1992-1995

$\mathrm{PhD}$, Urban and Public Affairs

University of Louisville

2000-2005

\section{PUBLICATIONS:}

Li, Songmei. (2003). Beyond Mapping. Proceedings of the $41^{\text {st }}$ Annual Conference for Urban and Regional Information Systems Association (URISA), Atlanta, GA. October 11-15.

Li, Songmei. (2003). Louisville's Red Water Story. Poster presentation at the American Water Works Association (AWWA) KY - TN Section Conference. Sep. 30 - Oct. 3.

Li, Songmei and Thomas S. Lyons. (2003). Survey Analysis of Wisconsin Business Incubation Programs in 2002. Report prepared for Wisconsin Business Incubation Association and Wisconsin Department of Commerce.

Li, Songmei and Chen Qi. (1993). Comparative Studies on Human Capital for International Economic, Trade and Financial Centers in Asia - Hong Kong, Singapore, Tokyo, and Shanghai. Report prepared for Human Resource Department, Shanghai Municipal Government. 